\title{
SELEÇÃO DE INDICADORES PARA O MONITORAMENTO DO USO PÚBLICO EM ÁREAS NATURAIS
}

\author{
ANNA JÚLIA PASSOLD
}

Engenheiro Florestal

Orientador: Prof. Dr. TERESA CRISTINA MAGRO

Dissertação apresentada à Escola Superior de

Agricultura "Luiz de Queiroz", Universidade de São Paulo, para obtenção do título de Mestre em Recursos Florestais, Área de Concentração: Recursos Florestais com opção em Conservação de Ecossistemas Florestais.

PIR A C I CA B A

Estado de São Paulo - Brasil

Fevereiro - 2002 


\title{
Dados Internacionais de Catalogação na Publicação (CIP) DIVISÃO DE BIBLIOTECA E DOCUMENTAÇÃO - ESALQ/USP
}

\author{
Passold, Anna Júlia \\ Seleçăo de indicadores para o monitoramento do uso público em áreas naturais / \\ Anna Júlia Passold. - - Piracicaba, 2002.
}

75 p. : il.

Dissertação (mestrado) - Escola Superior de Agricultura Luiz de Queiroz, 2002. Bibliografia.

1. Ecoturismo 2. Monitoramento - Impacto 3. Parques - Manejo 4. Reservas naturais - Indicadores 5. Visitantes I. Título

CDD 333.72 
ANNA JÚLIA PASSOLD. Seleção de indicadores para o monitoramento do uso público em áreas naturais./Dissertação (mestrado).

\begin{tabular}{|c|c|c|c|c|}
\hline p. & item & linha & onde se lê & leia-se \\
\hline 12 & 2.3 & décima terceira & $\begin{array}{l}\text {...a seleção da } \\
\text { metodologia }\end{array}$ & $\begin{array}{l}\text {...a seleção da } \\
\text { metodologia, seja } \\
\text { amostragem, } \\
\text { censo ou uma } \\
\text { combinação de } \\
\text { ambos,... }\end{array}$ \\
\hline 15 & 2.4 & sétima & $\begin{array}{l}\text {...indicadores } \\
\text { qualitativos são }\end{array}$ & $\begin{array}{l}\text {...indicadores } \\
\text { quantitativos são }\end{array}$ \\
\hline 16 & 2.4 & primeira & $\begin{array}{l}\text { expressos... } \\
\ldots \text {...ritérios do } \\
\text { Sustainable } \\
\text { Forest } \\
\text { Management } \\
\text { (SFM)... }\end{array}$ & $\begin{array}{l}\text { expressos... } \\
\text {...critérios do } \\
\text { Manejo Florestal } \\
\text { Sustentável... }\end{array}$ \\
\hline 21 & 3.1 .1 & décima sétima & $\begin{array}{l}\text {...dias chuvosos } \\
\text { varia de } 125 \text { a } \\
150 \mathrm{~mm}, \ldots\end{array}$ & $\begin{array}{l}\text {...dias chuvosos } \\
\text { variam de } 125 \text { a } \\
150, \ldots\end{array}$ \\
\hline 28 & 3.3 & vigésima oitava & $\begin{array}{l}\text {...sendo que } 22 \\
\text { trilhas e } 32\end{array}$ & $\begin{array}{l}\text {... sendo que } 22 \\
\text { trilhas e } 30\end{array}$ \\
\hline 38 & 3.5 & quinta & $\begin{array}{l}\text { indicadores... } \\
\ldots \text {..amostras de } \\
100 \mathrm{~m}, 50 \mathrm{~m}, . . .\end{array}$ & $\begin{array}{l}\text { indicadores... } \\
\ldots . \text { amostras de } \\
50 \mathrm{~m}, 50 \mathrm{~m}, . . .\end{array}$ \\
\hline 38 & 3.5 & nona & $\begin{array}{l}\text {..e Cachoeira da } \\
\text { Água Comprida } \\
(120 \mathrm{~m}) \ldots\end{array}$ & $\begin{array}{l}\text {..e Cachoeira da } \\
\text { Água Comprida } \\
(89 \mathrm{~m}) \ldots\end{array}$ \\
\hline 50 & 4.3 & segunda & $\begin{array}{l}\text {...contra } 8 \\
\text { significativos } \\
\text { (Tabela 17). }\end{array}$ & $\begin{array}{l}\text {...contra } 7 \\
\text { significativos } \\
\text { (Tabela 17). }\end{array}$ \\
\hline
\end{tabular}




\section{DEDICATÓRIA}

Ao único Deus, Salvador nosso, por Jesus Cristo, nosso Senhor, seja glória e majestade, domínio e poder, antes de todos os séculos, agora e para todo o sempre. Amém.

Mãe e pai, pra vocês und für meine Liebe Oma passold auch. 


\section{AGRADECIMENTOS}

Agradeço Aquele que é poderoso para me guardar de. tropeços e apresentar-me irrepreensível, com alegria, perante a Sua glória. O meu rochedo, o meu lugar forte, o meu libertador, o meu Deus, a minha fortaleza, em quem confio, o meu escudo, a força da minha salvação e o meu alto refúgio.

Aos meus pais, Leoba e Bráulio, que com amor e incentivo estiveram sempre presentes em todos os momentos da minha vida.

Minha querida Oma Irmgard Passold, que sempre me incentivou na língua alemã, e com quem aprendi à admirar os jardins e toda a natureza.

Às minhas irmãs Dani e Rafa, meu irmão Binho e as novas células da família Sawi e Bernardo.

A minha orientadora Teresa Cristina Magro, pelo incentivo, amizade e orientação no trabalho desenvolvido.

Ao prof. Walter de Paula Lima, pelo privilégio da orientação inicial da pesquisa.

À Fundação Coordenação de Aperfeiçoamento de Pessoal de Nível Superior (CAPES) pela bolsa concedida.

À Fundação o Boticário de Proteção à Natureza, cujo apoio possibilitou a execução da pesquisa.

Aos monitores do Parque Estadual Intervales, Sr. Eliseu, Luis, Faustino, Dito Amaral, Toninho, Zé Flóido, Aparício e Sr. Ditinho, pela imensa ajuda e companheirismo.

À todos os funcionários do parque, do escritório, recepção, viveiro, manutenção, vigilância, e em especial ao apoio dado pela Jeannette Vieira Gennen.

Ao prof. Hilton Thadeu $Z$. do Couto pelo grande auxílio no planejamento e análise dos dados. 
Ao prof. Álvaro Pires da Silva, pelo incentivo nos meus primeiros passos em uma nova área de pesquisa.

À Claudia, Herdjânia, Tairone e Jair, e funcionários do Laboratório de Física do Solo, que possibilitaram a realização de uma etapa ainda não concluída do trabalho.

À Kátia, Blanche, Maria Isabel, Silvia e Alexandre, pela disposição em contribuir na coleta de dados na Intervales.

Aos funcionários da Coopervales, em especial à Lucy e todas as cozinheiras pelas maravilhosas refeições e conversas acompanhadas de chá quente nos dias gelados.

Aos estagiários Rodrigo, Daniel e Aline.

Aos professores e funcionários do Departamento de Ciências Florestais e do IPËF pela ajuda dispensada.

Aos amigos Laerte, Fabiano, Valéria e Carla, pela convivência alegre e bem humorada e ajuda nos trabalhos.

Às companheiras do LANP, Adriana e Bebel, com quem pude compartilhar momentos preciosos deste trabalho.

Ao Ivo, que me ajudou e ensinou a lidar com os comportamentos inesperados de arquivos, programas, instalações.

À todos os colegas da pós-graduação.

À Marisol, pela cooperação no evangelho desde o primeiro dia até agora, que retenho com alegria no meu coração pois foi participante da minha graça em Cristo. À Milze, cuja palavra foi sempre agradável, temperada com sal, lembrando-me, sem cessar, da carreira que me foi proposta, do trabalho, da paciência, fazendo bem em tomar parte nas minhas aflições, perseverando em ser imitadora do Senhor, de maneira que sempre foi grande exemplo de fé. 


\section{SUMÁRIO}

Página

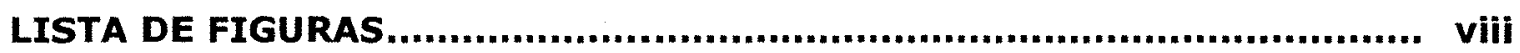

LISTA DE TABELAS ................................................................. ix

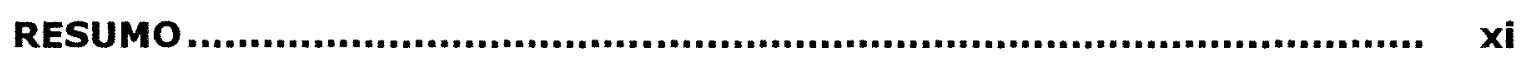

SUMMARY ............................................................................ xiii

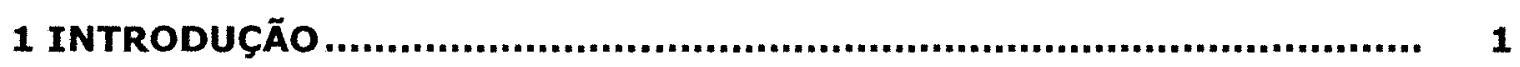

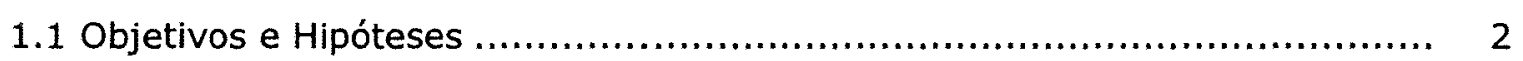

1.2 Resumo dos capitulos apresentados.......................................... 3

2 REVISÃO DE LITERATURA ................................................... 5

2.10 crescimento das atividades de turismo em áreas naturais ................... 5

2.2 Impactos do uso público e métodos de planejamento e avaliação ............... 6

2.3 Monitoramento de impactos recreacionais ................................. 10

2.4 Critérios e indicadores de impacto recreacional ................................ 13

3 MATERIAL E MÉTOdOS.............................................................. 20

3.1 Caracterização geral da área.................................................. 20

3.1.1 Relevo, clima, geologia, geomorfologia e solos .............................. 21

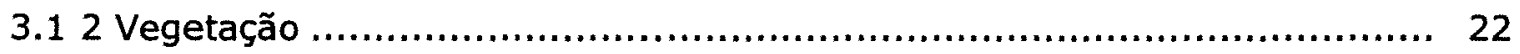

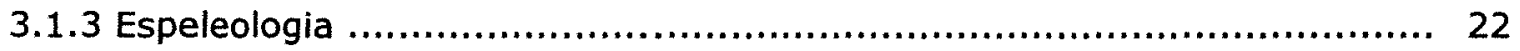

3.1.4 Administração do Parque Estadual Intervales ............................. 23

3.2 Visitação do Parque Estadual Intervales ....................................... 23

3.2.1 Caracterização do sistema de trilhas ....................................... 24

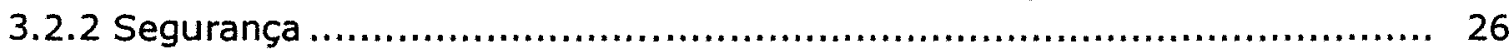

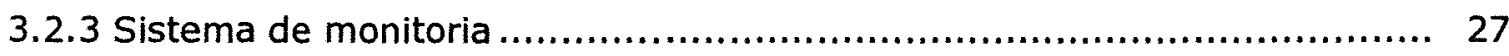


3.2.4 Agências e escolas.......................................................... 27

3.2.5 Estruturas atuais de orientação ao público ................................... 28

$3.3 \mathrm{O}$ indicador reage positivamente ao manejo? ................................ 28

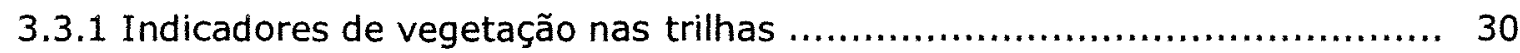

3.3.2 Indicadores de vegetação fora dos caminhos oficiais ........................ 31

3.3.3 Indicadores de leito da trilha ............................................... 32

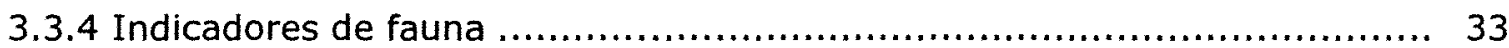

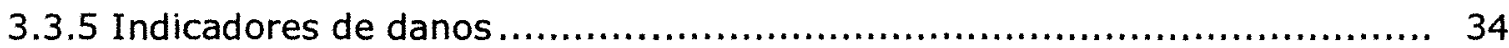

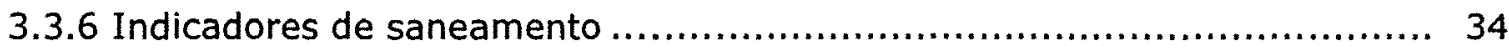

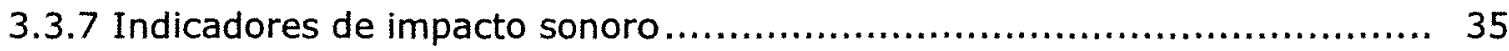

3.4 Avaliação de indicadores através de critérios de qualidade .................... 35

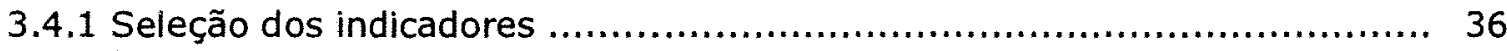

3. 5 Avaliadores diferentes coletam a mesma informação? ....................... 37

4 RESULTADOS E DISCUSSÃO ........................................................ 40

4.10 indicador reage positivamente ao manejo? ................................. 40

4.2 Avaliação de indicadores através de critérios de qualidade .................... 45

4.3 Avaliadores diferentes coletam a mesma informação? ......................... 47

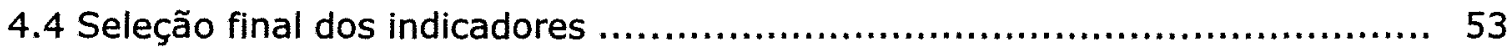

4.4.1 Indicadores selecionados segundo o critério referente à implementação das

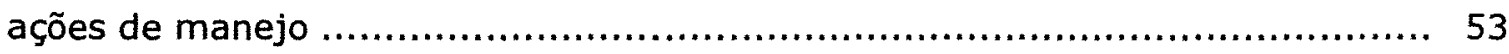

4.4.2 Indicadores selecionados segundo avaliação de critérios..................... 53

4.4.3 Indicadores selecionados segundo avaliação realizada por diferentes grupos........................................................................... 54

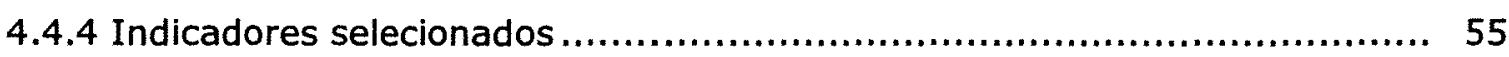

4.5 Caderno de registro de ocorrências.......................................... 57

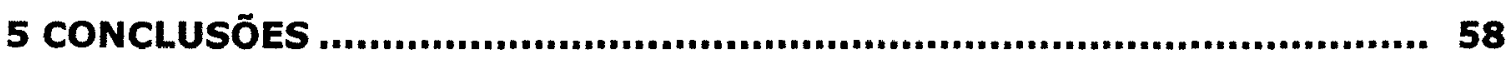

ANEXOS ......................................................................................... 60

REFERÊNCIAS BIBLIOGRÁFICAS ................................................ 69 


\section{LISTA DE FIGURAS}

Página

Figura 1 - Diagrama ilustrando objetivos pré-determinados dos sistemas de planejamento, LAC, VIM e VERP.

Figura 2- Número de visitantes com pernoite no Parque Estadual Intervales, no período de 1988 a 1998 (São Paulo, 2001).

Figura 3- Erosão lateral ao sentido de caminhamento da trilha. Fonte:Hesselbarth \& Vachowski, 1997)

Figura 4 - Erosão em canal, acompanhando o leito da trilha. Fonte:Hesselbarth \& Vachowski, 1997)

Figura 5 - Distribuição e quantidade de pontos amostrados em quatro trilhas.

Figura 6 - Porcentagem de mudança dos indicadores de leito, para trilhas de uso intensivo com e sem manejo implementado.

Figura 7 - Porcentagem de mudança dos indicadores de leito, para trilhas de uso moderado com e sem manejo implementado.

Figura 8- Porcentagem de mudança dos indicadores de leito para trilhas de baixo uso com e sem manejo implementado.

Figura 9 - Avaliação de indicadores quantitativos, (a) número de pedras expostas e (b) profundidade e qualitativos, (c) erosão, por diferentes grupos. 


\section{LISTA DE TABELAS}

Página

Tabela 1. Sistemas de planejamento para o manejo do uso público 9

Tabela 2. Classificação de diferentes métodos utilizados em programas de monitoramento e análise de impactos em trilhas

Tabela 3. Características de bons indicadores de qualidades segundo várias fontes 15

Tabela 4. Lista de possiveis indicadores de impactos ecológicos e sociais. 17

Tabela 5. Roteiros mais utilizados no ano de 1998 25

Tabela 6. Indicadores avaliados no monitoramento do uso público no Parque Estadual Intervales 29

Tabela 7. Listagem de indicadores quantitativos registrados em campo pelos grupos de avaliadores. 39

Tabela 8. Listagem de indicadores qualitativos registrados em campo pelos grupos de avaliadores.

Tabela 9. Valores e porcentagens de mudança ${ }^{a}$ para indicadores avaliados em trilhas de uso intensivo. 40

Tabela 10. Valores e porcentagens de mudança ${ }^{a}$ para indicadores avaliados em trilhas de uso moderado.

Tabela 11. Valores e porcentagens de mudança ${ }^{a}$ para indicadores avaliados em trilhas de baixo uso. 
Tabela 12. Total de respostas obtidas na avaliação dos indicadores

Tabela 13. Indicadores que se aplicam plenamente aos critérios estabelecidos

Tabela 14. Matriz de avaliação para seleção de indicadores que se aplicam plenamente aos critérios estabelecidos

Tabela 15. Indicadores com valores significativos e não significativos para análise comparativa entre o grupo de monitores e técnicos

Tabela 16. Indicadores com valores significativos e não significativos para análise comparativa entre individuos do grupo de monitores.

Tabela 17. Indicadores com valores significativos e não para análise comparativa entre indivíduos do grupo de técnicos.

Tabela 18. Valor-p e nível de significância na comparação dos indicadores avaliados entre grupos de monitores e técnicos, e indivíduos do mesmo grupo.

Tabela 19. Indicadores selecionados segundo critérios necessários e desejáveis.

Tabela 20- Matriz de seleção de indicadores de acordo com classes comparativas 


\title{
SELEÇÃO DE INDICADORES PARA O MONITORAMENTO DO USO PÚBLICO EM ÁREAS NATURAIS
}

\author{
Autora: ANNA JÚLIA PASSOLD \\ Orientador: Prof. TERESA CISTINA MAGRO
}

\section{RESUMO}

O planejamento e implantação de estratégias de manejo que permitam a realização de atividades recreacionais em áreas naturais protegidas, sem alterar significativamente os processos naturais, tem sido um dos desafios enfrentados pelos administradores dessas áreas. Os programas de monitoramento de impacto do uso público oferecem aos administradores uma ferramenta objetiva para acompanhar as condições naturais do meio, e verificar a amplitude do impacto causado pelos visitantes. Os métodos utilizados atualmente para avaliar os impactos decorrentes do crescente número de visitantes em áreas naturais, utilizam indicadores que refletem alterações ecológicas representativas ocasionadas pelo uso público. Indicadores eficientes para este objetivo apresentam características desejáveis que incluem: 1) diretamente observáveis, 2) relativamente fáceis de medir, 3) relacionados aos objetivos da área, 4) sensiveis às mudanças nas condições de uso e 5) respondem ao manejo. A seleção de indicadores torna-se portanto determinante para a implantação de programas de monitoramento eficientes. O tema principal desse estudo refere-se a escolha de indicadores de impacto do uso público que sejam efetivos, para o programa de monitoramento do uso público no Parque Estadual Intervales. 
Para atingir seus objetivos, o estudo propôs em linhas gerais: 1) a realização de um seminário com pesquisadores envolvidos com o parque, para discussão da efetividade dos indicadores utilizados no programa de monitoramento; 2) a avaliação dos indicadores através de critérios pré-estabelecidos; 3) teste de campo com os monitores locais e com especialistas em impactos da recreação, utilizando os indicadores selecionados e, 4) análise dos indicadores para detectar significativamente as diferenças entre os avaliadores; 5) seleção final dos indicadores. Para o Parque Estadual Intervales, os indicadores selecionados para monitoramento a cada dois anos, foram: presença de serrapilheira, número de árvores com raízes expostas, área de vegetação degradada, número de trilhas não oficiais, presença de lixo, número de árvores danificadas. Indicadores relacionados com acontecimentos esporádicos e que não são diretamente observáveis no momento da medição, devem ser registrados em um livro de ocorrências. Estes indicadores referem-se à ocorrências relacionadas com as condições das trilhas, com a fauna, vegetação, acidentes, e comportamento do visitante. 


\section{CHOOSING INDICATORS FOR MONITORING PUBLIC USE IN NATURAL AREAS}

Author: ANNA JÚLIA PASSOLD

Adviser: Prof. TERESA CRISTINA MAGRO

\section{SUMMARY}

A program for managing protected areas, permitting the free play of natural processes unaffected by human influence, presents managers with difficulties. The recreation-impact monitoring programs offer managers an objective tool for documenting the natural conditions, processes, and the extent of human influence. The monitoring programs being used today to assess visitor related impacts include the use of indicators that are able to represent the ecological changes caused by recreation. Usefull indicators will include those that are directly observable, relatively easy to measure, directly related to the objectives for the area, sensitive to changing use conditions, and amenable to management. The indicator's selection is a critical issue to the best use of monitoring programs. The aim of this study was to choose indicators that can best be used on the recreation impact monitoring system in Intervales State Park. To achieve these goals, the study proposes, 1) to host a seminar with researches involved with the park to discuss the effectiveness of the currently used indicators in the monitoring program; 2) indicators were evaluated using specific criteria; 3 ) to conduct field work with local monitoring and 
with specialists in recreation impact; and 4) analysis of the difference between local monitoring personnel and specialists; 5) final indicators were chosen. In Intervales, indicators were chosen for monitoring every two years: amount of litter cover, number of trees with root exposure, extend of reduction in vegetation cover, number of not-official trails, amount of litter, number of trees damaged. 


\section{INTRODUÇÃO}

A busca por atividades de recreação ao ar livre e o desenvolvimento do turismo na natureza no Brasil, resultou no aumento da visitação em áreas naturais, trazendo impactos indesejáveis aos recursos existentes nestas áreas.

Os efeitos das atividades recreacionais incluem impactos sobre a vegetação, o solo, a fauna, a água e a qualidade da visitação.

Reconhecendo que os impactos estão associados ao crescente uso, instituições que administram os parques nos EUA, procuraram maneiras de incorporar conceitos baseados na capacidade de carga recreacional nos processos de planejamento. Assim, o primeiro instrumento de planejamento proposto para melhorar o manejo das áreas protegidas foi o Limits of Acceptable Change - LAC (Stankey et al. 1985). Outros instrumentos de planejamento foram propostos posteriormente, Visitor Impact Management - VIM (Graefe et al. 1990; Kuss et al. 1990) e Visitor Experience and Resource Protection - VERP proposto em 1993 (National Park Service, 1997) Os processos destes métodos são similares conceitualmente e foram desenvolvidos especificamente para lidar com a questão da capacidade de suporte em áreas silvestres e em parques nacionais (Cole \& McCool, 1997). A principal ênfase apresentada nestes métodos está no conceito de que as decisões de manejo estão baseadas nas condições do recurso, e não nos níveis de visitação e desenvolvimento de infra-estrutura.

Para que as ações de manejo sugeridas nas etapas finais dos métodos citados possam ser avaliadas, é necessária a implantação de um programa de monitoramento, onde se utilizam indicadores e padrões de qualidade que caracterizam os objetivos de manejo da área natural. 
Diversos estudos sugerem indicadores e critérios de seleção para utilização em programas de monitoramento (Magro, 1999; Belnap, 1998; Graefe et al., 1990; Kuss et al., 1990). No entanto, Belnap (1998) aponta que pouca atenção foi dada aos estudos que enfocassem o processo de seleção dos indicadores. Informações atualizadas sobre a intensidade, extensão e distribuição do uso são também citadas por Leung e Marion (1999a), com fatores críticos para a avaliação dos indicadores e dos padrões utilizados em programas de manejo do uso público.

No Brasil, trabalhos referentes à seleção e avaliação de indicadores para o monitoramento do uso público não foram encontrados. Entretanto, alguns autores utilizam indicadores para a avaliação de impactos recreacionais (Takahashi, 1998; Magro, 1999; Carvalho, 2000). O Plano de Manejo do Parque Nacional do Iguaçu (Magro e Freixêdas, 1998) também apresenta o uso de indicadores para o monitoramento do uso público no capítulo referente à capacidade de carga do parque. Mais recente, o Plano de Uso Público do Parque Nacional do Itatiaia (Magro et al., 2000) aponta a necessidade do uso de algum sistema de monitoramento do uso público com o uso de indicadores.

Leung e Marion (2000) fazem uma revisão das pesquisas desenvolvidas nos últimos 15 anos relacionadas aos impactos recreacionais e manejo das áreas naturais. Os autores destacam que para alguns indicadores os resultados sugerem uma considerável subjetividade na avaliação. Para que os dados monitorados reflitam realmente as mudanças nas condições do recurso natural são necessárias pesquisas que caracterizem e encontrem novas formas de reduzir os erros de medição.

Este estudo, conduzido no Parque Estadual Intervales, descreve o processo de avaliação de indicadores utilizando-se critérios de qualidade propostos por Graefe et al. (1990), Belnap (1998) e Krumpe (2000), e a seleção destes para o monitoramento do uso público em áreas naturais.

\subsection{Objetivos e Hipóteses}

Reconhecendo deficiências metodológicas na avaliação de impactos recreacionais no Parque Estadual Intervales, a seguinte questão foi proposta para direcionar o estudo: Os indicadores utilizados no levantamento de impactos 
respondem da mesma forma ao serem avaliados por indivíduos ou grupos diferentes?

As hipóteses desenvolvidas para responder a esta questão referem-se às diferenças nas comparações entre três grupos (técnicos e monitores, indivíduos do grupo de técnicos e indivíduos do grupo de monitores):

Hipótese 1. Os indicadores avaliados não apresentam diferenças significativas entre o grupo de técnicos e monitores.

Hipótese 2. Os indicadores avaliados não apresentam diferenças significativas entre individuos do grupo de monitores.

Hipótese 3. Os indicadores avaliados não apresentam diferenças significativas entre individuos do grupo de técnicos.

A premissa de que não deve haver diferenças significativas entre medições realizadas por diferentes avaliadores é um dos critérios para elegibilidade de bons indicadores de qualidade do recurso natural.

Outro critério foi utilizado para determinar a efetividade das estratégias de manejo propostas para o Parque Estadual Intervales, baseado na seguinte questão: Os indicadores respondem às ações de manejo implementadas? A hipótese proposta para responder a esta questão é:

Hipótese 4. Os indicadores respondem de forma positiva às ações de manejo implantadas no Parque Estadual Intervales.

\subsection{Resumo dos capítulos apresentados}

A parte textual desta dissertação é apresentada na forma tradicional, incluindo as seguintes subdivisões:

Capítulo 1: Introdução. Tem por objetivo apresentar os antecedentes que justificam o estudo $\mathrm{e}$ as hipóteses que fundamentaram os objetivos a serem alcançados.

Capítulo 2: Revisão de literatura. Apresenta informações correlatas ao tema em estudo, reforçando trabalhos já realizados e que necessitam de confirmação e continuação. Neste capítulo são caracterizados conceitos e a evolução das pesquisas referentes à avaliação de impactos do uso público, metodologias de avaliação utilizadas, etapas de desenvolvimento dos métodos e a forma de coleta dos dados. 
Capítulo 3: Material e métodos. Descreve a forma de coleta dos dados e o processo de seleção dos indicadores.

Capítulo 4: Resultados e discussão. Apresenta os resultados comparativos entre indicadores avaliados por diferentes grupos e as deduções com base nas hipóteses formuladas. Descreve as dificuldades encontradas na avaliação em campo e as implicações para o futuro monitoramento utilizando-se os indicadores selecionados. Fornece uma análise da efetividade dos indicadores com base nos critérios analisados.

Capítulo 5: Conclusões. Destaca-se a principal contribuição deste trabalho, apontando recomendações desenvolvidas com base nos capítulos anteriores, e situando-o no contexto temático apresentado. 


\section{REVISÃO DE LITERATURA}

\subsection{0 crescimento das atividades de turismo em áreas naturais}

O drástico crescimento do turismo ao longo dos últimos 50 anos é apontado por Francesco Frangialli (World Tourism Organization, 2001) como um dos maiores fenômenos econômicos e sociais do período. O número internacional de turistas cresceu, em termos reais, de 25 milhões em 1950 para 698 milhões em 2000. Atualmente, a atividade do turismo está em primeiro lugar no contexto da economia mundial. A previsão apontada pela Organização Mundial de Turismo (World Tourism Organization, 2001) indica a continuidade desta tendência, esperando-se um aumento de mais de 1 milhão de turistas em 2010 e mais 1.5 milhões até 2020.

Reconhecendo a expansão das atividades de ecoturismo nas últimas duas décadas, as Nações Unidas declararam o ano de 2002 como o Ano Internacional do Ecoturismo. Dados do WTTC (World Travel \& Tourism Council) informam que o turismo ecológico representa hoje, entre 5 a $8 \%$ do negócio turismo, devendo atingir $15 \%$ do movimento total em 2005. 0 topo das montanhas, os oceanos e as áreas naturais remotas serão os principais destinos turísticos do próximo milênio, segundo a previsão da Organização Mundial de Turismo (World Tourism Organization, 1998). Na Conferência sobre Gestão e Desenvolvimento Sustentado do Ecoturismo nas Américas, realizada em agosto de 2001 em Cuiabá, o ministro de Estado de Esporte e Turismo Dr. Carlos Melles formalizou o lançamento oficial do projeto denominado Pólos de Desenvolvimento de Ecoturismo. Este projeto identificou, em todo o território nacional, 96 regiões (pólos) que apresentam potencial para o desenvolvimento de atividades de ecoturismo (Brasil, 2001). 
Os números do Instituto de Ecoturismo do Brasil mostram a atratividade deste novo negócio no Brasil. Em 1994, o ecoturismo foi responsável pela movimentação de $R \$ 2,2$ bilhões. Em 1995, esta cifra pulou para $R \$ 3$ bilhões, um salto de $36 \%$ em apenas um ano, muito acima da média mundial, de $20 \%$, que já é muito superior à expansão de qualquer segmento de negócios. Estima-se que em 2005 o Ecoturismo deverá movimentar 10,8 bilhões de dólares no Brasil (Brasil, 2001).

O Brasil é reconhecido como um dos lugares do mundo que possui mais atrativos para todos os perfis de ecoturistas e condições inigualáveis para a prática de todas as modalidades de ecoturismo - exceto as que exijam neve. As unidades de conservação, devido as suas características intrínsecas, com beleza cênica e ambientes primitivos que oferecem a oportunidade para esportes de aventura e contato com a natureza, tem sido um dos destinos mais procurados para a prática destas atividades.

Brito (2000) destaca que juntamente com a atividade de pesquisa, o ecoturismo em unidades de conservação vem crescendo no Brasil em qualidade e quantidade. E coloca que em termos da gestão das unidades, o que tem ocorrido é que o ecoturismo tem oferecido aos administradores uma dimensão "palpável" de sua "performance administrativa" e da imagem que a unidade tem para o público. Essa avaliação "informal" tem suscitado nesses administradores a busca da melhoria das condições de atendimento, tanto no que se refere à infra-estrutura de apoio, quanto à necessidade de treinamento dos funcionários.

No entanto, o uso das unidades de conservação para o desenvolvimento de atividades de turismo traz efeitos positivos e negativos, tanto para o ambiente como para as comunidades vizinhas. O uso de métodos de avaliação de impactos constituem um importante instrumento de planejamento aos administradores na implantação de programas de visitação em áreas naturais protegidas.

\subsection{Impactos do uso público e métodos de planejamento e avaliação}

O aumento da visitação em áreas naturais e o fato destas áreas, por vezes, coincidirem com ecossistemas frágeis, causam impactos negativos sobre 0 ambiente, que poderiam ser evitados ou diminuídos com algumas propostas de 
manejo. As áreas de uso público das unidades de conservação brasileiras, cujos Planos de manejo não foram atualizados, foram planejadas para atender uma demanda menor do que a atual, com atividades menos impactantes e com um público diferente daquele que freqüenta atualmente as áreas naturais protegidas.

Para conciliar o uso recreativo destas áreas com seus outros objetivos primários, relacionados à conservação dos recursos naturais e a pesquisa científica, os locais designados para o desenvolvimento de atividades de uso público devem ser manejados para controlar os efeitos negativos sobre o ambiente e para garantir a qualidade da experiência do visitante (Freixêdas-Vieira et al., 2000).

De acordo com Magro (1999) os impactos negativos mais comuns, oriundos do uso público, são demonstrados pela perda da vegetação e conseqüente erosão do solo, presença de lixo, contaminação de água, incêndios e distúrbio da fauna. Parte dos impactos somente pode ser identificada após exaustivo levantamento e monitoramento dos recursos, comparando locais sem visitação e sob diferentes intensidades de uso. Os impactos que respondem facilmente ao uso e que podem ser diretamente observáveis, se constituem em um instrumento muito útil para os administradores das unidades de conservação. A partir do levantamento com os de indicadores selecionados, torna-se possivel acompanhar as modificações no ambiente e controlar o uso em locais onde possam ocorrer alterações que comprometam a qualidade ambiental.

Krumpe (2000) aponta que durante certo período, os estudos referentes ao manejo de áreas naturais, contribuíram muito pouco para a responder à questões sobre o monitoramento e avaliação da implementação dos planos de manejo. Com a visão negativa do papel da ciência nos planos de manejo de áreas naturais, durante duas décadas os administradores concordaram que pesquisas técnicas e cientificamente eficazes poderiam prover as respostas necessárias para desenvolver planos de manejo mais efetivos. Surgiu então nos EUA e Canadá, a partir de 1978, cinco instrumentos de planejamento e zoneamento, comumente citados por suas siglas: ROS (Recreation Opportunity Spectrum), LAC (Limits of Acceptable Change), VIM (Visitor Impact Management), VAMP (Visitor Activities Management Process) e em 1993 o VERP (Visitor Experience and Resource Protection).

Estes métodos transformam os diferentes instrumentos legais (constituição federal, constituição estadual, leis, códigos, decretos, resoluções e portarias) em objetivos claros, que podem ser implementados e avaliados com padrões, definindo 
os limites de mudança aceitáveis para os indicadores ecológicos e sociais selecionados (Figura 1).

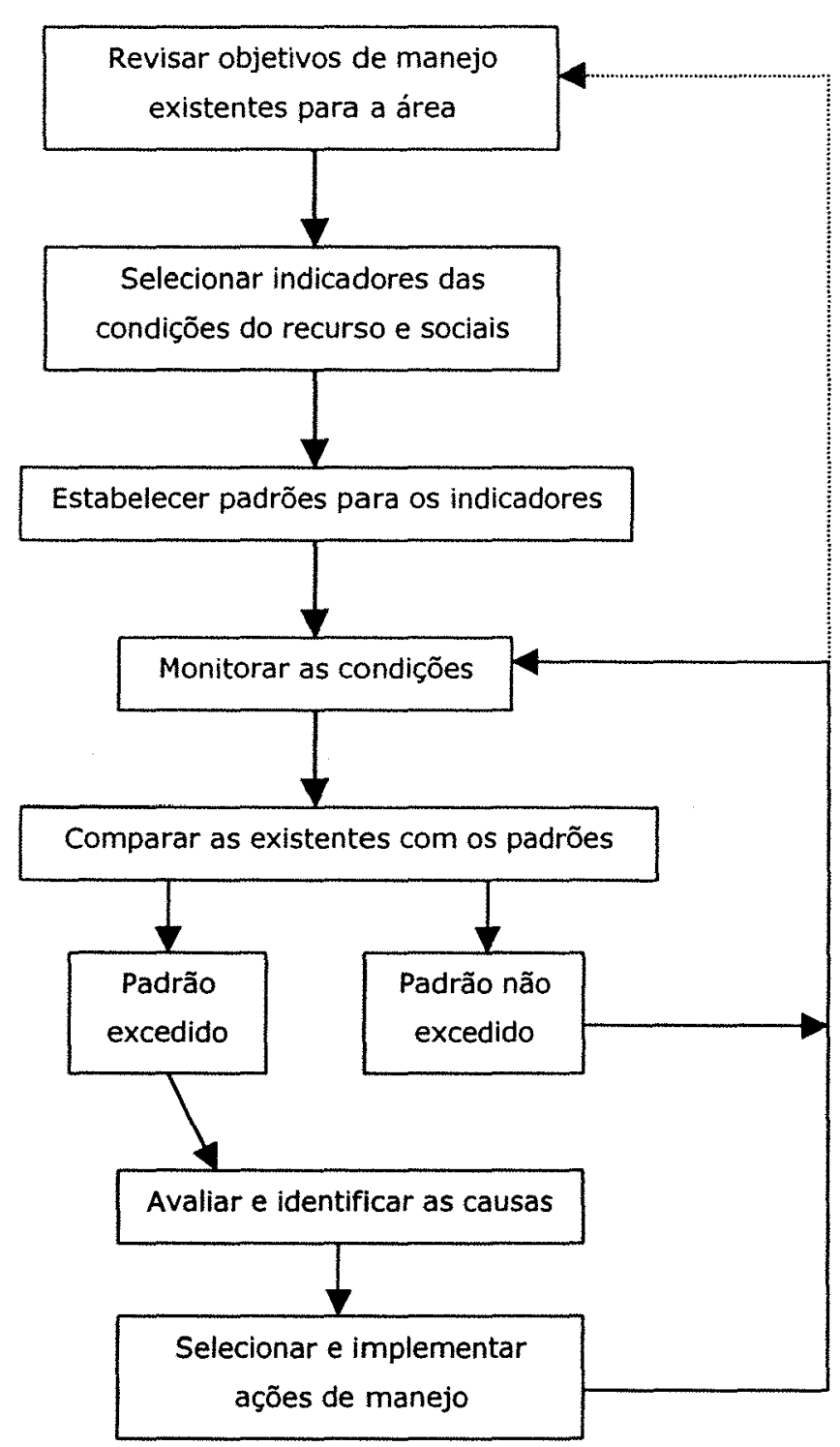

Fonte: Leung \& Marion (2000)

Figura 1 - Diagrama ilustrando objetivos pré-determinados dos sistemas de planejamento, LAC, VIM e VERP. 
Desde então, os conceitos inerentes ao estudo de impactos passaram por uma rápida evolução, sendo que, atualmente, a maior parte dos métodos baseia-se nas condições sociais e ambientais desejadas para o futuro, avaliando-se se as ações de manejo estão produzindo os resultados esperados sem alterar outras características da experiência ou do ambiente. Na Tabela 1 estão descritos os passos básicos dos sistemas de planejamento do uso público mais utilizados nos EUA.

O modelo ROS - Recreation Opportunity Spectrum (Clark \& Stankey, 1979), é atualmente considerado por diversos autores como um instrumento de zoneamento, e não um método de planejamento.

Tabela 1. Sistemas de planejamento para o manejo do uso público

\begin{tabular}{|c|c|c|}
\hline LAC & VIM & VERP \\
\hline $\begin{array}{l}\text { Passo 1: Identificar as áreas de } \\
\text { interesse e sua distribuição }\end{array}$ & $\begin{array}{l}\text { Passo 1: Pré - avaliação e } \\
\text { revisão de informações }\end{array}$ & $\begin{array}{l}\text { Passo 1: Reunir uma equipe } \\
\text { interdisciplinar para o projeto }\end{array}$ \\
\hline $\begin{array}{l}\text { Passo 2: Definir e descrever as } \\
\text { classes de oportunidade }\end{array}$ & $\begin{array}{l}\text { Passo 2: Revisão dos objetivos } \\
\text { de manejo }\end{array}$ & $\begin{array}{l}\text { Passo 2: Desenvolver uma } \\
\text { estratégia para envolver o } \\
\text { público }\end{array}$ \\
\hline $\begin{array}{l}\text { Passo 3: Selecionar os } \\
\text { indicadores das condições } \\
\text { ecológicas e sociais desejadas }\end{array}$ & $\begin{array}{l}\text { Passo 3: Seleção dos } \\
\text { indicadores de impacto }\end{array}$ & $\begin{array}{l}\text { Passo 3: Desenvolver propostas } \\
\text { referentes aos objetivos } \\
\text { primários do parque, } \\
\text { importância, e temas } \\
\text { interpretativos }\end{array}$ \\
\hline $\begin{array}{l}\text { Passo 4: Levantar as condições } \\
\text { ecológicas e sociais }\end{array}$ & $\begin{array}{l}\text { Passo 4: Seleção dos padrões } \\
\text { para os indicadores de impacto }\end{array}$ & $\begin{array}{l}\text { Passo 4: Analisar o recurso } \\
\text { natural e uso público existente } \\
\text { no parque }\end{array}$ \\
\hline $\begin{array}{l}\text { Passo 5: Especificar padrões } \\
\text { para os indicadores }\end{array}$ & $\begin{array}{l}\text { Passo 5: Comparação de } \\
\text { padrões e condições existentes }\end{array}$ & $\begin{array}{l}\text { Passo 5: Descrever os níveis de } \\
\text { experiência dos visitantes e as } \\
\text { condições do meio natural }\end{array}$ \\
\hline $\begin{array}{l}\text { Passo 6: Determinar a } \\
\text { distribuição das diversas opções }\end{array}$ & $\begin{array}{l}\text { Passo 6: Identificação das } \\
\text { causas prováveis dos impactos }\end{array}$ & $\begin{array}{l}\text { Passo 6: Determinar a } \\
\text { localização de possiveis áreas } \\
\text { de uso }\end{array}$ \\
\hline $\begin{array}{l}\text { Passo 7: Identificar as ações de } \\
\text { manejo para cada opção }\end{array}$ & $\begin{array}{l}\text { Passo 7: Identificação das } \\
\text { estratégias de manejo }\end{array}$ & $\begin{array}{l}\text { Passo 7: Selecionar indicadores } \\
\text { e especificar padrões para cada } \\
\text { área; desenvolver um programa } \\
\text { de monitoramento }\end{array}$ \\
\hline $\begin{array}{l}\text { Passo 8: Avaliar e selecionar } \\
\text { uma opção } \\
\text { Passo 9: Implementar ações de } \\
\text { manejo e monitorar as condições }\end{array}$ & Passo 8: Implementação & $\begin{array}{l}\text { Passo 8: Monitorar indicadores } \\
\text { ecológicos e sociais } \\
\text { Passo 9: Implementar ações de } \\
\text { manejo }\end{array}$ \\
\hline
\end{tabular}

Fonte: Manning \& Lime (2000)

LAC = Limits of Acceptable Change VIM= Visitor Impact Management

VERP $=$ Visitor Experience and Resource Protection 
No Brasil, o método mais utilizado foi da capacidade de carga recreacional (Cifuentes, 1992), que usa como base o número máximo de pessoas que um determinado ambiente pode suportar, sem que seja alterada a qualidade ambiental e também a qualidade da experiência da visita.

Esta mudança reflete uma clara diferença de enfoque no manejo das áreas naturais protegidas, e os três métodos citados fornecem ferramentas adequadas para trabalhos desta natureza.

\subsection{Monitoramento de impactos recreacionais}

As trilhas em áreas naturais protegidas desempenham tanto a função de prover acesso e oportunidades recreacionais aos visitantes, quanto proteger o recurso, concentrando o uso nos caminhos planejados e mais resistentes. Entretanto, as condições de degradação das trilhas, evidenciadas através de diferentes tipos de impacto, tais como a erosão e problemas de drenagem, diminuem valores funcionais e recreacionais, agravando o possivel efeito ecológico da paisagem, e utilizando o escasso recurso financeiro disponivel para a manutenção destas áreas (Cole 1983; Forman, 1995).

Dada a importância dos impactos em trilhas, tratando-se de assuntos relacionados ao manejo, é fundamental que as decisões dos administradores de áreas naturais protegidas estejam baseadas em informações objetivas e confiáveis. Estas informações, complementadas com dados referentes à utilização do recurso pelo visitante, permite a análise dos fatores que influenciam o tipo, a severidade, e a extensão do impacto nas trilhas. Quando coletadas periodicamente, como parte de um programa de monitoramento, tal informação pode auxiliar na identificação de mudanças antes do impacto tornar-se muito severo ou irreversível, prevendo tendências e avaliando a efetividade das estratégias de manejo implementadas Estas informações exigem o desenvolvimento de programas eficientes e confiáveis de monitoramento de impacto, cuja aplicação vem crescendo mundialmente nas áreas naturais protegidas, necessitando ser incorporadas à metodologias de planejamento e manejo, como os modelos ROS, LAC, VIM, VAMP e VERP. (Leung \& Marion, 1999). 
Leung \& Marion (1999) apontam que estudos sobre trilhas vêm sendo amplamente direcionados para os efeitos do pisoteio humano $e$ os fatores que afetam a degradação, mas que apesar da sua importância, a análise de metodologias que avaliam e monitoram impactos nas trilhas são raramente documentadas na literatura. Os programas de avaliação e monitoramento de impactos utilizam métodos de censo ou amostragem, com alguns estudos que combinam ambos, como mostra a Tabela 2. Cada abordagem envolve múltiplos indicadores e medidas, que podem gerar informações importantes para os administradores de áreas naturais protegidas (Cole, 1993).

Tabela 2. Classificação de diferentes métodos utilizados em programas de monitoramento e análise de impactos em trilhas

\begin{tabular}{|c|c|c|c|c|}
\hline Abordagem & Método & Implementação & Exemplos & Locais \\
\hline \multirow[t]{2}{*}{ Amostragem } & $\begin{array}{l}\text { Amostragem } \\
\text { sistemática de } \\
\text { pontos }\end{array}$ & $\begin{array}{l}\text { São estabelecidas } \\
\text { distâncias fixas entre } \\
\text { pontos de observação ou } \\
\text { medição ao longo da } \\
\text { trilha }\end{array}$ & Cole (1993) & $\begin{array}{l}\text { Trilhas na região de } \\
\text { Montana, USA }\end{array}$ \\
\hline & $\begin{array}{l}\text { Amostragem } \\
\text { estratificada de } \\
\text { pontos }\end{array}$ & $\begin{array}{l}\text { Plano de amostragem } \\
\text { (intervalo, tipos de } \\
\text { medição) variando ao } \\
\text { longo do estrato }\end{array}$ & $\begin{array}{l}\text { Hall e Kuss (1989) } \\
\text { Summer (1980) }\end{array}$ & $\begin{array}{l}\text { Trilhas em Parques } \\
\text { Nacionais na } \\
\text { Virgínia, USA } \\
\text { Trilhas em Parques } \\
\text { Nacionais no } \\
\text { Colorado, USA }\end{array}$ \\
\hline \multirow[t]{2}{*}{ Censo } & $\begin{array}{l}\text { Avaliação de } \\
\text { seções }\end{array}$ & $\begin{array}{l}\text { Trilha dividida em seções } \\
\text { de igual comprimento, } \\
\text { com avaliação de } \\
\text { problemas de impacto } \\
\text { feitos para cada seção }\end{array}$ & $\begin{array}{l}\text { Lajeunesse et al. } \\
(1997) \\
\text { Braton et al. (1979) }\end{array}$ & $\begin{array}{l}\text { Trilhas em parques } \\
\text { urbanos de } \\
\text { Montreal, Canadá } \\
\text { Trilhas em Parques } \\
\text { Nacionais no } \\
\text { Tenessee/North } \\
\text { Carolina, USA }\end{array}$ \\
\hline & $\begin{array}{l}\text { Avaliação do } \\
\text { problema }\end{array}$ & $\begin{array}{l}\text { Problemas de impacto são } \\
\text { predefinidos, seguido de } \\
\text { um censo completo de } \\
\text { tais problemas }\end{array}$ & $\begin{array}{l}\text { Hawes (1996) } \\
\text { Marion (1994) }\end{array}$ & $\begin{array}{l}\text { Trilhas na Tasmânia, } \\
\text { Australia } \\
\text { Parques Nacionais } \\
\text { no Tenessee/North } \\
\text { Carolina, USA }\end{array}$ \\
\hline Integrativo & & $\begin{array}{l}\text { Combinação de duas } \\
\text { aproximações ou mais } \\
\text { numa única análise }\end{array}$ & $\begin{array}{l}\text { Cole et al. (1997) } \\
\text { Bayfield and Lloyd } \\
(1973)\end{array}$ & $\begin{array}{l}\text { Trilhas em Oregon e } \\
\text { Washinton, USA } \\
\text { Trilha de longa } \\
\text { distância em trilhas } \\
\text { na Inglaterra, Reino } \\
\text { Unido }\end{array}$ \\
\hline
\end{tabular}


Sistemas de monitoramento são destacados em diversos programas que visam alcançar níveis de qualidade, através do melhor planejamento e manejo. Assim cita-se a norma ISO (International Organization for Standardization) que desenvolveu um sistema internacional de manejo ambiental, denominado ISO 14.000. Na ISO 14.001, o Sistema de Manejo Ambiental (EMS -Environmental Management System) divide-se em três categorias: i) política e planejamento; ii) implementação; e iii) Monitoramento e aperfeiçoamento.

Van Bueren \& Blom (1997), ressaltam a importância do monitoramento, apontando que se trata de uma atividade científica que fornece uma visão do funcionamento do sistema, destacando procedimentos e operações de manejo atualmente utilizados e a forma como devem ser ajustados para alcançar os objetivos desejados.

De acordo com Leung \& Marion (1999), a seleção da metodologia para o levantamento de dados é definida principalmente pelos objetivos e o padrão de manejo da área em questão. Utilizando-se o método LAC, ou outros métodos, os padrões de manejo podem ser determinados conforme o seguinte exemplo: (1) A largura média de qualquer trilha não deveria exceder os 2 metros; (2) A trilha não deveria apresentar mais que $5 \%$ de sulcos ou canais de erosão, definido como um segmento onde o canal excede $30 \mathrm{~cm}$ de profundidade ao longo de mais de $10 \mathrm{~m}$ na trilha, considerando seu comprimento total.

O primeiro padrão de manejo exemplificado, requer a caracterização da largura da trilha com um nível razoável de precisão, sendo que levantamentos utilizando o método amostral são mais apropriados na obtenção destes dados. Já o segundo padrão apresentado requer uma medida do conjunto ou estimação, na extensão da trilha que apresenta problemas inaceitáveis. Os levantamentos que utilizam censo são geralmente mais apropriados para obtenção da contagem e dimensão dos problemas em todos os segmentos da trilha, embora levantamentos baseados em amostragem possam também ser utilizados para avaliação (Cole, 1983).

Segundo Leung \& Marion (1999), a determinação da localização, dimensão e severidade dos problemas em todos os segmentos da trilha, obtidas através do censo, ou enumeração completa, perfazem satisfatoriamente toda a demanda por informação na determinação dos padrões de manejo. No entanto, levantamentos baseados em censo despendem tempo e custos, e requerem especialistas com 
prática em identificar cada impacto incidente no campo. Como resultado, poucos programas de monitoramento de impactos em trilhas, baseados em levantamentos do tipo censo foram desenvolvidos, e muitos têm utilizado níveis de medição considerados grosseiros.

Frequentemente, os administradores das áreas naturais protegidas utilizam levantamentos baseados em amostragem, seja por reduzir o tempo no campo como por permitir a medição de indicadores de impacto e características físicas e biológicas em maior detalhe nos pontos amostrais (Cole, 1983). Entretanto, a utilização da amostragem está assegurada na suposição de que as amostras são representativas das condições encontradas na trilha, que devem ser aproximadas aos resultados de um levantamento utilizando-se o censo completo.

Leung \& Marion (1999) estudaram a influência do intervalo de amostragem mais representativo entre pontos de avaliação, para Programas de Monitoramento de Impactos, em 72 trilhas no Great Smoky Mountains National Park, totalizando $520 \mathrm{~km}$ de extensão. Os resultados apontam que intervalos amostrais com cerca de 100 metros mostraram ser os mais exatos em estimativas de impacto na trilha, $\mathrm{e}$ intervalos de 100 à 500 metros são também recomendados.

\subsection{Critérios e indicadores de impacto recreacional}

Para selecionar estratégias de manejo eficientes, que reduzam ou controlem os impactos, os administradores das áreas naturais protegidas necessitam de informações objetivas e atualizadas da intensidade, extensão e o padrão de distribuição das diferentes formas de impacto (Leung \& Marion, 1999b).

Do mesmo modo, estas informações são fundamentais para avaliar indicadores e padrões nos modelos de planejamento e manejo baseados na capacidade de carga, como Limits of Acceptable Change (LAC) e Visitor Experience and Resource Protection (VERP), (Stankey et al.,1985; NPS, 1997).

A ênfase dada aos indicadores nos últimos 15 anos surgiu como um resultado direto da aplicação dos modelos de manejo, como o LAC, VIM e VERP, (Leung \& Marion, 2000), sendo a seleção de indicadores e o monitoramento periódico um componente fundamental nestes sistemas. 
Indicadores são definidos como variáveis de impacto mensuráveis que refletem a condição geral de conservação de um parque (Lah, 2000). Cole (1994) define que indicadores são parâmetros específicos que podem ser monitorados para avaliar o sucesso dos programas de manejo, e devem contemplar todos os impactos causados pelo uso público.

De acordo com Graefe et al. (1990), é importante reconhecer que não há um único indicador ou um conjunto de indicadores apropriados para todas as situações. A escolha de indicadores depende do tipo de impacto em questão e de características particulares do local.

Diversos critérios podem ser utilizados para avaliar a aplicabilidade de outros indicadores. Os indicadores usualmente utilizados incluem aqueles que são diretamente observáveis, relativamente fáceis de medir, diretamente relacionados aos objetivos de manejo da área, sensíveis às mudanças nas condições de uso e passíveis de manejo (Graefe et al. ,1990).

A escolha de indicadores é também necessária para especificar o nível de detalhe no qual os indicadores selecionados devem ser medidos e avaliados. A escala de medição pode ser alcançada tanto através de índices ecológicos sofisticados, utilizando métodos quantitativos, como métodos de avaliação visual subjetiva (Graefe et al., 1990).

Diversos estudos foram conduzidos para a determinação de critérios que pudessem ser utilizados na definição de indicadores de qualidade para as áreas naturais (Manning, 2000; Davis, 2000, National Park Service, 1997; Graefe et al.; 1990; Stankey et al. 1985). Para Manning (2000), estes critérios podem ser utilizados para facilitar a compreensão do papel dos indicadores e padrões de qualidade e para ajudar a avaliar e selecionar possíveis indicadores.

o documento síntese da fase conceitual do SIMBIO, referente ao monitoramento da biodiversidade em unidades de conservação federais (Brasil, 1999), apresenta uma lista com as principais características para a construção de "bons" indicadores (Tabela 3).

Um conjunto de critérios para a seleção de indicadores, segundo Graefe (1990), Krumpe (2000), Manning (2000) e Brasil (1999) no relatório interno SIMBIO, é apresentado na Tabela 3. 
Tabela 3. Características de bons indicadores de qualidades segundo várias fontes

\begin{tabular}{|c|c|c|c|}
\hline Graefe (1990) & Krumpe (2000) & Manning (2000) & $\begin{array}{l}\text { SIMBIO, Brasil } \\
\text { (1999) }\end{array}$ \\
\hline $\begin{array}{l}\text { Diretamente } \\
\text { observável }\end{array}$ & $\begin{array}{l}\text { Capaz de alertar com } \\
\text { antecedência a condição de } \\
\text { degradação inaceitável }\end{array}$ & $\begin{array}{l}\text { Padrões devem ser expressos } \\
\text { em termos quantitativos }\end{array}$ & Barato \\
\hline Fácil de medir & $\begin{array}{l}\text { Detecta mudanças que } \\
\text { persistem por longos } \\
\text { periodos }\end{array}$ & $\begin{array}{l}\text { Espaço de tempo limitado (por } \\
\text { dia, por noite, por percurso) } \\
\text { para expressar padrões de } \\
\text { distribuição do uso recreacional }\end{array}$ & $\begin{array}{l}\text { Informação } \\
\text { disponível e } \\
\text { concentrada }\end{array}$ \\
\hline $\begin{array}{l}\text { Relacionado aos } \\
\text { objetivos da área }\end{array}$ & $\begin{array}{l}\text { Reflete outras condições } \\
\text { relacionadas ao impacto }\end{array}$ & $\begin{array}{l}\text { Padrão deve incluir a } \\
\text { probabilidade de que as } \\
\text { condições estabelecidas sejam } \\
\text { alcançadas (não mais que } 3 \\
\text { encontros de grupos por dia } \\
\text { durante } 80 \% \text { da temporada de } \\
\text { verão) }\end{array}$ & Simples \\
\hline $\begin{array}{l}\text { Relacionado ao } \\
\text { uso público }\end{array}$ & $\begin{array}{l}\text { Distingue se a mudança foi } \\
\text { causada pelo uso } \\
\text { recreacional ou condições } \\
\text { naturais }\end{array}$ & & $\begin{array}{l}\text { Rigorosamente } \\
\text { definido }\end{array}$ \\
\hline \multirow[t]{5}{*}{$\begin{array}{l}\text { Responde ao } \\
\text { manejo }\end{array}$} & $\begin{array}{l}\text { Sensivel à mudanças que } \\
\text { ocorrem no período de um } \\
\text { ano }\end{array}$ & & Padronizado \\
\hline & Reponde ao manejo & & $\begin{array}{l}\text { Orientado para o } \\
\text { manejo }\end{array}$ \\
\hline & $\begin{array}{l}\text { Pode ser medido } \\
\text { quantitativamente }\end{array}$ & & Objetivo \\
\hline & $\begin{array}{l}\text { Pode ser medido por } \\
\text { diferentes observadores } \\
\text { que receberam treinamento }\end{array}$ & & Não ambíguo \\
\hline & $\begin{array}{l}\text { Pode ser medido com } \\
\text { equipamentos e técnicas de } \\
\text { amostragem simples }\end{array}$ & & $\begin{array}{l}\text { Disponivel em } \\
\text { tempo oportuno }\end{array}$ \\
\hline
\end{tabular}

Van Bueren \& Blom (1997), na ampla discussão internacional sobre o desenvolvimento de princípios, critérios e indicadores para o manejo florestal sustentável (C\&I), definem indicadores quantitativos e qualitativos. Segundo os autores, indicadores qualitativos são expressos e avaliados em termos de quantidade, com dados numéricos, volumes, porcentagens. Indicadores qualitativos expressam a situação, objeto, ou processo em termos de satisfação, como satisfatório, suficiente, insatisfatório e respostas do tipo sim/não. Os autores afirmam que indicadores quantitativos são preferíveis aos qualitativos, pois estes frequentemente são ambíguos. Para muitos critérios importantes não existem indicadores quantitativos, sendo difícil ou impossivel desenvolvê-los. Em 
compensação, para diversos critérios do Sustainable Forest Management (SFM) ainda não é possível a utilização de indicadores quantitativos, uma vez que o limitado conhecimento científico disponível não permite o estabelecimento de normas quantitativas. Neste caso, indicadores quantitativos não têm significância como valor de referência.

O uso de indicadores qualitativos tem sido mais comum que o de quantitativos. Na Austrália, a grande predominância de indicadores qualitativos, é justificada por Sun e Walsh (1998) devido ao pequeno número de estudos experimentais. Para os autores uma das principais razões para a falta de informação do relacionamento quantitativo entre os impactos ambientais e o grau do uso turístico é que existem insuficientes estudos feitos usando uma abordagem experimental. Os poucos estudos experimentais se concentram em poucos tipos de impactos, geralmente pisoteio, que embora sejam mais fácil de medir raramente tem um grande valor ecológico.

Krumpe (2000) discute formas de como a pesquisa pode contribuir para a melhoria do planejamento e manejo de áreas naturais protegidas, destacando, entre outras, a busca por indicadores-chave. Especificamente, indicadores que são sensíveis ao uso humano, e que apresentam rápida mudança em resposta ao impacto inicial.

É importante também omitir indicadores redundantes, quando for apropriado. Esta atitude, segundo Leung e Marion (1999), pode reduzir o tempo de trabalho de campo ou permitir medições de outros indicadores de impacto que não são representados pelo presente fator.

Não existe nenhuma resposta ambiental ou comportamental previsível e única em relação ao uso recreativo. Algumas formas de impacto são mais diretas ou óbvias que outras, entretanto, um indicador ou combinação de indicadores de impacto pode tornar-se a base para a estratégia de manejo a ser adotada (Hendee et al., 1990).

O terceiro passo do método VIM envolve a identificação de indicadores mensuráveis relacionados aos objetivos de manejo da área. Uma vez que os objetivos de manejo foram descritos, fornecendo as condições de proteção e experiência do visitante esperadas no parque, esta etapa serve para identificar de que forma estas condições podem ser medidas. Portanto, nesta etapa devem ser selecionadas as variáveis e atributos mais importantes como indicadores das 
condições desejadas. Uma lista de possíveis indicadores ecológicos e sociais é demostrada na Tabela 4.

Tabela 4. Lista de possiveis indicadores de impactos ecológicos e sociais.

\section{IMPACTOS FÍSICOS}

Densidade do solo
Compactação do solo
pH do solo
Quantidade de serrapilheira e camada orgânica
superficial
Área sem vegetação

Área total de camping

Tamanho das áreas das fogueiras

Erosão visivel
Drenagem do solo

Química do solo

Produtividade do solo

Profundidade de serapilheira e camada orgânica

Área de solo nu

$N^{\circ}$ de fogueiras

$N^{\circ}$ de trilhas não oficiais

\section{IMPACTOS BIOLÓGICOS}

Fauna do solo e micro flora

$\%$ de perda de cobertura vegetal

Diversidade de espécies de plantas

Altura das plantas

Extensão de vegetação doente

$\mathrm{N}^{\circ}$ de plântulas

Abundância de espécies silvestres

Frequência de observação de fauna silvestre

Sucesso na reprodução da fauna silvestre
Densidade de cobertura do solo

Composição de espécies de plantas

Proporção de espécies. exóticas

Vigor das espécies selecionadas

Extensão dos danos às árvores

Exposição das raízes das árvores

Presença/Ausência de fauna silvestre

selecionada

Diversidade de fauna silvestre

\section{IMPACTOS SOCIAIS}

$N^{\circ}$ de encontros com outros indivíduos/dia $\mathrm{N}^{\circ}$ de encontros por meio de transporte $N^{\circ}$ de encontros com outros grupos por dia $\mathrm{N}^{\circ}$ de encontros por local de encontro Percepção do visitante sobre o impacto no ambiente

Satisfação do visitante

Relatos de visitantes sobre comportamento indesejável de outros visitantes
$N^{\circ}$ de encontros por tipo de atividade $\mathrm{N}^{\circ}$ de encontros por tamanho de grupo Percepção do visitante sobre lotação $\mathrm{N}^{\circ}$ de reclamações dos visitantes Quantidade de lixo na área

Fonte: Graefe et al. (1990) 
Segundo Magro (1999), além de relacionar parâmetros físicos, indicadores do grau de impacto devem ser listados também os problemas relacionados ao manejo dos recursos, sob o ponto de vista institucional. São estes os fatores, na verdade que determinam a aplicação ou não de técnicas adequadas de planejamento e manejo.

Leung e Marion (2000) classificam os indicadores de impacto em 4 grupos: 1) Indicadores que representam a severidade do dano, como índices de diversidade de espécies e índices de similaridade entre populações; 2) Indicadores de qualidade que representam a extensão e distribuição dos impactos, como a área da trilha danificada, nível de expansão de áreas de camping e áreas próximas; 3) Indicadores que apresentam um resumo das condições de conservação do recurso no local, como a perda de vegetação e grau de impacto; 4) Indicadores de sensibilidade aos impactos, como indicadores de resistência e resiliência.

A aplicação dos indicadores em programas de monitoramento e estudo específicos é demostrada nos trabalhos de Abidin (2000), Krumpe (2000), Whitecotton et al. (2000), Boyers (2000), Magro (1999), Belnap (1998), Graefe et al. (1990), Kuss et al. (1990), Graefe et al, 1990; Vimmerstedt (1982).

No estudo de caso apresentado por Belnap (1998), os processos utilizados na seleção de indicadores de impacto da visitação para o Arches Nacional Park, em Utah-USA são aplicáveis à várias áreas que apresentam mudanças similares. No estudo foram: (1) identificados tipos vegetacionais influenciados pelos visitantes, sendo amostradas tanto áreas impactadas quanto não impactadas, comparando-se a vegetação e fatores do solo; (2) encontradas variáveis que diferem significativamente na comparação entre locais utilizando-os como indicadores em potencial; (3) desenvolvidos critérios locais específicos para os indicadores, e avaliados indicadores potenciais utilizando-se estes critérios; (4) escolhidos indicadores adicionais pesquisados, com relevância ecológica; (5) selecionados indicadores definitivos, testados em campo e escolhidos locais de monitoramento. No Arches National Park, alguns indicadores são monitorados anualmente (superfície do solo, compactação do solo, número de trilhas utilizadas e estabilidade dos agregados do solo) e outros a cada cinco anos (cobertura vegetal, cobertura e composição química do solo).

Watson et al. (1990) desenvolveram uma lista de indicadores freqüentemente utilizados pelo U.S. Forest Service, porém não se tem 
conhecimento sobre a aplicabilidade destes em programas de monitoramento para as áreas silvestres do National Park Service, pois não foram testados.

Apenas um número restrito de variáveis é utilizada na avaliação dos impactos recreacionais nas áreas de uso intensivo dos parques, sendo portanto fundamental a seleção destes indicadores. 


\section{MATERIAL E MÉTODOS}

\subsection{Caracterização geral da área}

O Parque Estadual Intervales, está localizado ao sul do Estado de São Paulo, entre a Serra de Paranapiacaba e o Vale do Ribeira, compreendendo os municípios de Guapiara, Ribeirão Grande, Sete Barras, Eldorado e Iporanga, entre as

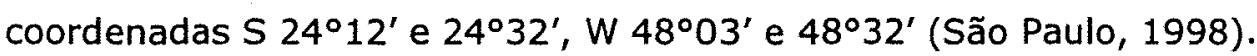

Abrangendo antiga fazenda do Banco do Estado de São Paulo - BANESPA, adquirida pela Fundação Florestal - Secretaria de Estado do Meio Ambiente, e agregando terras devolutas, compreende 41.705 ha de patrimônio natural (São Paulo, 2001). O Parque Estadual Intervales foi a última grande área com remanescente de Mata Atlântica declarada especialmente protegida de forma restritiva em São Paulo, embora sua conservação estivesse assegurada desde a aquisição em 1987 (São Paulo, 1998).

Interligado ao Parque Estadual Carlos Botelho, Parque Estadual do Alto Ribeira - PETAR e Estação Ecológica Xitué, e em associação com a Zona de Vida Silvestre da Área de Proteção Ambiental (APA) da Serra do Mar e a zona núcleo da Reserva da Biosfera da Mata Atlântica ${ }^{1}$, compõe o chamado continuum ecológico de Paranapiacaba, com cerca de 120.000 ha (São Paulo, 1998).

O estudo foi conduzido na área da sede administrativa do parque, localizada à 800 metros de altitude, com média anual de precipitação entre 1.200 e 1.500 $\mathrm{mm}$. De acordo com a classificação climática de Köeppen, o clima da região apresenta-se como $\mathrm{Cfb}$, com temperaturas médias anuais de $22^{\circ} \mathrm{C}$ no mês mais quente (fevereiro), e abaixo de $18^{\circ} \mathrm{C}$ no mês mais frio (julho).

\footnotetext{
${ }^{1}$ A Reserva da Biosfera da Mata Atlântica (RBMA) foi reconhecida pela Unesco em 1991. Integra parcelas territoriais de 113 municípios apenas no Estado de São Paulo.
} 
Aberto para a visitação pública desde 1995, o parque vem recebendo um número cada vez maior de visitantes, o que resultou no uso intensivo das trilhas, gerando impactos indesejáveis ao recurso natural e à qualidade da visitação.

\subsubsection{Relevo, clima, geologia, geomorfologia e solos}

A altitude do parque varia de $60 \mathrm{~m}$, abrangendo porções da planície do rio Ribeira do Iguape, estendendo-se à vertente atlântica da serra da Paranapiacaba, à $1.095 \mathrm{~m}$ atingindo o divisor de águas entre as bacias dos rios Ribeira de Iguape e Paranapanema. O clima da área da baixada, segundo a classificação de Köeppen, é do tipo Af, significando clima tropical chuvoso de floresta. Em São Paulo (1998), o clima é classificado como sendo clima meridional permanentemente úmido, onde a atuação de massas polares (50\%) sobrepuja a atuação das massas tropicais. As temperaturas médias dos meses mais quentes apresentam-se superiores a $22^{\circ} \mathrm{C}$, e as temperaturas mínimas absolutas anuais chegam a $-4^{\circ} \mathrm{C}$ nas altitudes mais elevadas, ocorrendo de um a cinco dias de geada por ano. O total de dias chuvosos varia de 125 a $150 \mathrm{~mm}$, com média de precipitações anuais de $2.000 \mathrm{~mm}$ (São Paulo, 1998).

A Serra da Paranapiacaba, onde se situa o Parque Estadual Intervales, é parte do Complexo Cristalino, que ocorre ao longo da costa brasileira desde a Bahia até o Rio Grande do Sul, cujo embasamento é formado por rochas ígneas, principalmente o granito, e metamórficas, predominando o gnaisse, migmatitos, xistos, filitos, quartzitos, mármores e calcários, com rochas de 450 milhões a 3 bilhões de anos (São Paulo, 2001).

Os principais solos encontrados sobre a Serra da Paranapiacaba são rasos, como os solos litólicos e os cambissolos, ocorrendo ainda os solos podzólicos vermelho-amarelos e os latossolos vermelho-amarelos, em geral pobres em nutrientes e ácidos, podendo haver associações e gradações entre vários deles. As encostas com $30^{\circ}$ a $32^{\circ}$ de declividade apresentam baixa estabilidade, permitindo deslizamentos e avalanches, e declividades de $37^{\circ}$ a $40^{\circ}$ suportam apenas solos litólicos. Por isso, ocorrem geralmente solos rasos nos topos e encostas declivosas e solos profundos no sopé das montanhas e encostas mais suaves. Os solos sob a vegetação na encosta atlântica têm importância mais relevante na capacidade de 
armazenamento de água e de suporte das espécies arbóreas de diferentes tamanhos. Estes solos, na maioria, são pobres em bases trocáveis, lixiviados e ácidos, acarretando o desenvolvimento de sistemas radiculares superficiais. Assim, a ciclagem de nutrientes é excepcionalmente eficiente, através da decomposição da matéria orgânica na serapilheira. Como uma das adaptações que as espécies de árvores apresentam à declividade do terreno e aos solos rasos, ressalta-se a ocorrência de raízes tabulares ou sapopemas (São Paulo, 2001).

\subsection{Vegetação}

De acordo com São Paulo (2001), as características fisiográficas observadas em Intervales favorecem a ocorrência de florestas genericamente denominadas Mata Atlântica. São florestas que se situam sob climas distintos, mais quente e úmido nas baixas altitudes e encostas voltadas para o Vale do Ribeira e mais frio nas maiores altitudes e reversos da Serra de Paranapiacaba. Estas florestas são chamadas Pluviais ou Ombrófilas, por desenvolverem-se sob climas úmidos, sem períodos de estiagem. Nos topos de morro ocorre a floresta baixa, chamada Mata Nebular ou Floresta Ombrófila Densa Alto - Montana. A decomposição da matéria orgânica nos solos sob estas florestas é lenta devido às menores temperaturas. Em alguns topos de morro, sob solos muito rasos, observam-se também campos naturais. A complexidade estrutural das florestas mais desenvolvidas acarreta o estabelecimento de diferentes hábitos no seu interior, permitindo a ocorrência de espécies diferentemente adaptadas. Variações locais no substrato, como os afloramentos rochosos ou a existência de matacões, condicionam variações acentuadas na estrutura interna da floresta, que pode apresentar o seu subbosque mais ou menos denso.

\subsubsection{Espeleologia}

A região da Intervales foi visitada por espeleólogos pela primeira vez em 1972 - 73, época em que o parque era propriedade do BANESPA. Na ocasião foram exploradas e cadastradas três cavernas, destacando-se a dos Paiva, então com 
$2.880 \mathrm{~m}$ topografados. Trata-se até hoje, da maior caverna da região de Intervales, e uma das maiores do Estado, ainda não totalmente topografada mas já ultrapassando 4.500m. Em 1988, com a então Fazenda Intervales sob a administração da Fundação Florestal, deu-se início a um projeto sistemático de estudo espeleológico na área (São Paulo, 2001).

Como resultado, até o momento Intervales conta com mais de 50 cavernas topografadas e cadastradas (incluindo dados não publicados), cuja fauna foi objeto de uso extensivo. Dessa forma, segundo Trajano \& Gnaspini (São Paulo, 1992), Intervales passa a ser uma das regiões brasileiras mais bem conhecidas bioespeleologicamente e um dos raros exemplos da aplicação dos resultados de pesquisa básica nos programas de utilização turística de cavernas.

\subsubsection{Administração do Parque Estadual Intervales}

O Parque Estadual Intervales encontra-se inteiramente regularizado sob o aspecto fundiário e, com suas divisas estabelecidas em campo, possuindo ecossistemas bastante intocados e uma sede estruturada que atende a muitos visitantes, Intervales é considerado o Parque Estadual mais consolidado em São Paulo (São Paulo, 2001).

A administração atual mantém os programas de gestão, correspondendo às atividades de administração, manutenção, fiscalização, apoio à pesquisa e monitoramento ambiental, educação ambiental e atendimento à visitação, e interação sócio-ambiental. A unidade conta com uma cooperativa, denominada de Serviços Múltiplos de Ribeirão Grande - COOPERVALES, formada por moradores da região, que atua em parceria com a administração, sendo responsável principalmente pela administração do restaurante (São Paulo, 2001).

\subsection{Visitação do Parque Estadual Intervales}

O Parque Estadual Intervales recebe basicamente dois tipos de visitantes: i) hóspedes, que passam mais de um dia no parque e utilizam-se das acomodações ali existentes; ii) visitantes que permanecem durante um dia, permanecendo grande 
parte do tempo na área dos quiosques, e são em sua maioria visitantes regionais. Os visitantes do primeiro grupo são os maiores usuários do sistema de trilhas do Parque.

O número de visitantes no PEI vem aumentando nos últimos anos. Os dados da Figura 2 correspondem ao número de hóspedes que permanecem no parque durante, no mínimo, dois dias.

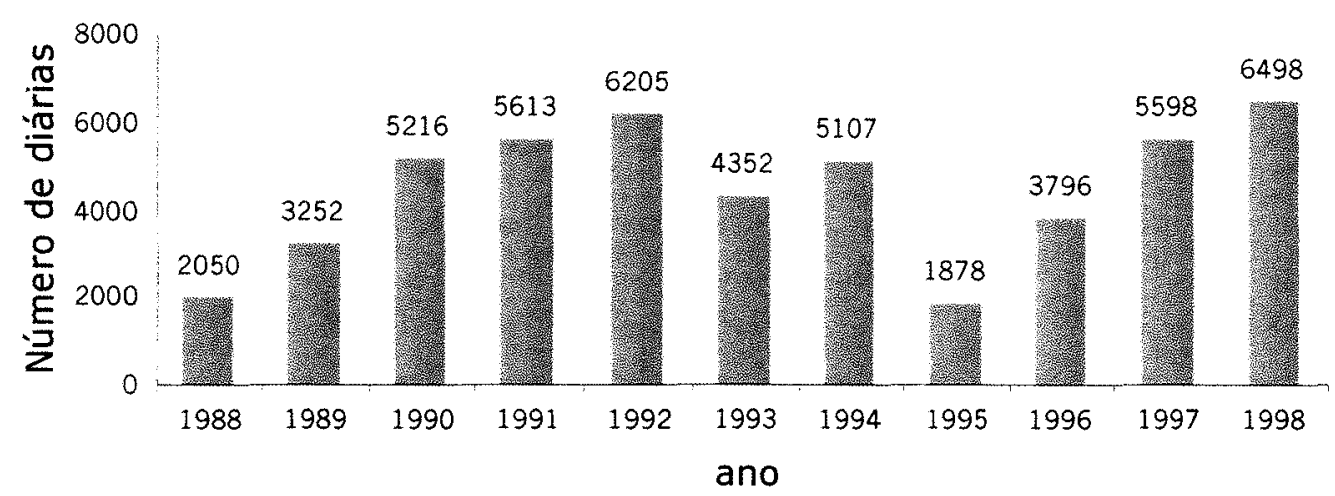

Figura 2- Número de visitantes com pernoite no Parque Estadual Intervales, no período de 1988 a 1998 (São Paulo, 1998).

A administração do Parque realizou um levantamento sobre o perfil do visitante e os dados revelaram que os usuários de 1998 são provenientes principalmente da cidade de São Paulo, seguida de diversas cidades do interior.

\subsubsection{Caracterização do sistema de trilhas}

O Parque Estadual Intervales possui um ampio sistema de trilhas e estradas, muitas delas implantadas durante a administração do Banespa. Através de levantamentos e avaliação do potencial mineral da região, grande parte das cavernas tornou-se conhecida. Algumas trilhas e estradas eram utilizadas para atividades administrativas e outras se constituem em caminhos históricos, utilizados por moradores da região para atividades de lavoura, caça e transporte. 
Com a gestão da Fundação Florestal, os caminhos e trilhas existentes foram aproveitados para propiciar aos visitantes o conhecimento de ambientes de caverna, interação da vegetação com as rochas, afloramentos de calcário, etc. Além disso, novas trilhas foram abertas e outras reformuladas em parte de seus percursos, visando incorporar outros atrativos como cachoeiras e mirantes. A Tabela 5 mostra os roteiros mais utilizados no ano de 1998.

Tabela 5. Roteiros mais utilizados no ano de 1998

\begin{tabular}{|c|c|c|c|c|}
\hline Roteiros Utilizados em $1998^{2}$ & Grupos & Pessoas & Média & $\begin{array}{l}\% \text { em relação ao } \\
\text { total de pessoas* }\end{array}$ \\
\hline Gruta dos Paiva & 117 & 1795 & 15,3 & $22 \%$ \\
\hline Gruta Colorida & 114 & 1523 & 13,4 & $19 \%$ \\
\hline Gruta Colorida e Cachoeira do Mirante & 62 & 1005 & 16,2 & $12 \%$ \\
\hline Cachoeira do Mirante & 48 & 573 & 11,9 & $7 \%$ \\
\hline Cachoeira da Água Comprida & 35 & 331 & 9,5 & $4 \%$ \\
\hline Trilha da Caçadinha & 27 & 292 & 10,8 & $4 \%$ \\
\hline Mirante da Anta & 29 & 273 & 9,4 & $3 \%$ \\
\hline Gruta do Fendão & 24 & 272 & 11,3 & $3 \%$ \\
\hline Gruta do Minotauro & 23 & 209 & 9,1 & $3 \%$ \\
\hline Gruta do Arcão & 22 & 222 & 10,1 & $3 \%$ \\
\hline Gruta do Fogo & 18 & 253 & 14,1 & $3 \%$ \\
\hline Gruta do Fogo e da Santa & 12 & 262 & 21,8 & $3 \%$ \\
\hline Quiosque e Piscina & 6 & 228 & 38,0 & $3 \%$ \\
\hline Gruta da Mãozinha & 23 & 192 & 8,3 & $2 \%$ \\
\hline Trilha Auto-Gulada & 6 & 144 & 24,0 & $2 \%$ \\
\hline Torre da Espla & 12 & 112 & 9,3 & $1 \%$ \\
\hline Roda D'Água & 8 & 102 & 12,8 & $1 \%$ \\
\hline Caminho dos Lagos & 6 & 91 & 15,2 & $1 \%$ \\
\hline Projeto Escola & 4 & 77 & 19,3 & $1 \%$ \\
\hline Bloterra & 3 & 86 & 28,7 & $1 \%$ \\
\hline Mirante Velho & 3 & 24 & 8,0 & $0 \%$ \\
\hline Cachoelra da Água Comprida e Gruta Colorida & 3 & 36 & 12,0 & $0 \%$ \\
\hline Gruta do Fendão e Mãozinha & 2 & 18 & 9,0 & $0 \%$ \\
\hline Grutas Colorida, Mãozinha e Minotauro & 2 & 37 & 18,5 & $0 \%$ \\
\hline Barra Grande & 2 & 21 & 10,5 & $0 \%$ \\
\hline Base do Carmo & $\underline{2}$ & 2 & 1,0 & $0 \%$ \\
\hline
\end{tabular}

* Onde aparece o número zero refere-se à utilização com menos de $1 \%$ de frequência.

Os dados de visitação mostram que apenas três trilhas concentram $60 \%$ das pessoas que realizam passeios no Parque, sendo elas a trilha da Gruta dos Paiva em

\footnotetext{
${ }^{2}$ Os nomes dos roteiros foram determinados a partir das informaçōes contidas nas fichas de registro dos monitores.
} 
primeiro lugar, a trilha da Gruta Colorida em segundo e a trilha da Cachoeira do Mirante em terceiro. Um dos motivos da trilha da Gruta dos Paiva receber muita visitação deve-se ao fato de ser a maior gruta da região.

De acordo com o Plano de Gestão (São Paulo, 1998), a Gruta dos Paiva está localizada na região da sede, mas em área externa ao Parque. Entretanto, vem sendo estudada há anos, mesmo antes da administração da Intervales pela Fundação Florestal. Apresenta grande importância como patrimônio espeleológico e alta concentração de fauna característica de ambientes subterrâneos. É considerada como a terceira maior gruta calcária do Estado de São Paulo.

Existem alguns locais de visitação bastante procurados pelos visitantes e que não se encontram na área do parque, mas na propriedade das Indústrias Votorantin S/A, que cede o uso das trilhas ao PEI. São elas as trilhas da Gruta dos Paiva, Cachoeira do Arcão, Cachoeira Luminosa e Gruta do Fendão.

Além das trilhas oficiais, existem diversos acessos que possibilitam a passagem de uma trilha à outra. Os acessos muitas vezes são criados pelos próprios monitores, com o intuito de facilitar o percurso para os visitantes ou evitar trechos que consideram em mal estado de conservação. Muitos destes acessos não são mais utilizados. Outra ação de manejo adotada refere-se ao controle de acesso de veículos às antigas estradas, implantadas desde a década de 50 pela empresa CIRAP, e mais tarde até meados da década de 70 pela administração do BANESPA.

\subsubsection{Segurança}

A segurança é um importante indicador de impactos sociais da visitação. Não há registros escritos de ocorrências envolvendo acidentes, mas grande parte dos acontecimentos ocorridos no PEI, relatados pelos funcionários e administração, envolvem deficiências no sistema de segurança ou alguma desatenção com as normas de segurança nas trilhas e cavernas. Geralmente envolvem acidentes com os visitantes como torção de pé, pequenos cortes em rochas, galhos e no interior de cavernas devido à vestimenta inadequada nas caminhadas e atividades. 


\subsubsection{Sistema de monitoria}

O grupo de monitores do parque, encarregados de acompanhar turistas, visitantes e pesquisadores, ao contrário da tendência dominante à época em que foi formado, não tem formação universitária (São Paulo, 1998). Ele se constitui por pessoas que conhecem a região, e antes do trabalho de monitoria podem ter sido agricultores, palmiteiros e caçadores. O que se buscou e, como hoje já está constatado, foi transformar estes homens da terra em formadores de opinião, multiplicadores de conceitos e práticas conservacionistas e agentes de difusão de informações sobre o parque. O contato destes com pesquisadores aprimora o seu conhecimento, permitindo-Ihes servir melhor aos visitantes, o que acaba gerando benefícios para todos e enriquecendo a vivência proporcionada com o trabalho desenvolvido no parque.

Atualmente, o PEI conta com seis monitores e todas as visitas às cavernas, cachoeiras e trilhas devem obrigatoriamente ser percorridas com 0 acompanhamento desses guias. Para isso, o visitante faz a sua inscrição nos passeios disponíveis, cuja lista é divulgada na Monitoria. Existem duas opções de horários para saída dos grupos: às 9:30h ou às 14:30h e o limite de visitantes por grupo é de quinze pessoas. A orientação para divulgação e escolha dos passeios tem sido a de ter apenas um grupo por período em cada uma das trilhas, evitando encontros.

\subsubsection{Agências e escolas}

O Parque Estadual Intervales possui grande potencial, tanto para o chamado ecoturismo, quanto para "estudos do meio" realizados por escolas. Alguns colégios têm realizado com frequência esse tipo de atividade em que, acompanhados por professores e pelos próprios monitores do $\mathrm{PEI}$, os alunos percorrem trilhas e exploram grutas a fim de conhecerem a realidade atual da Mata Atlântica. Há seqüências de passeios que são preparadas de forma a orientar e organizar esse estudo, como o Projeto Escola e excursões organizadas pela agência Bioterra. Em geral, o material de estudo é fornecido pelo próprio colégio ou agência responsável pela vinda dos estudantes. 
Outras agências de ecoturismo atuam principalmente na cidade de São Paulo, levando grupos de visitantes nos finais de semana e nos meses de férias. Não há um trabalho especifico realizado com esses turistas e a programação dos passeios é feita pelas agências e pelos próprios visitantes de forma particular.

Em uma pesquisa recente, realizada pelo próprio PEI a respeito dos instrumentos de divulgação que influenciaram a ida do visitante ao Parque, pode-se notar a grande participação de agências de ecoturismo independentes e ligadas às escolas, que aparecem em primeiro lugar na lista dos que mais atraem visitantes ao parque. Note-se, ainda, o acréscimo de visitantes nos meses de agosto, setembro e outubro, que são mais utilizados pelas escolas em suas viagens de estudo.

\subsubsection{Estruturas atuais de orientação ao público}

O Parque conta com um Centro de Visitantes localizado ao lado da Monitoria, que contém uma pequena exposição de curiosidades da Unidade e da região. Uma sala de vídeo, durante todo o dia exibe filmes ambientais para orientação dos visitantes com capacidade para 50 pessoas. A recepção possui um grande espaço vazio que anteriormente foi utilizado para exposições. O Centro de Convivência localizado próximo à Hospedaria é um espaço destinado a cursos e palestras para grupos maiores. Existe uma pequena loja destinada à venda de souvenirs do Parque, que se localiza no restaurante, gerenciado pela Coopervales.

\subsection{0 indicador reage positivamente ao manejo?}

Em janeiro de 1999 foi realizado o primeiro levantamento de impactos do uso público no Parque Estadual Intervales, sendo que 22 trilhas e 32 indicadores foram avaliados e analisados com base no método VIM. Em janeiro e fevereiro de 2001 iniciou-se o monitoramento das condições naturais, utilizando-se os mesmos indicadores (Tabela 6) avaliados em 1999. 
Tabela 6. Indicadores avaliados no monitoramento do uso público no Parque Estadual Intervales

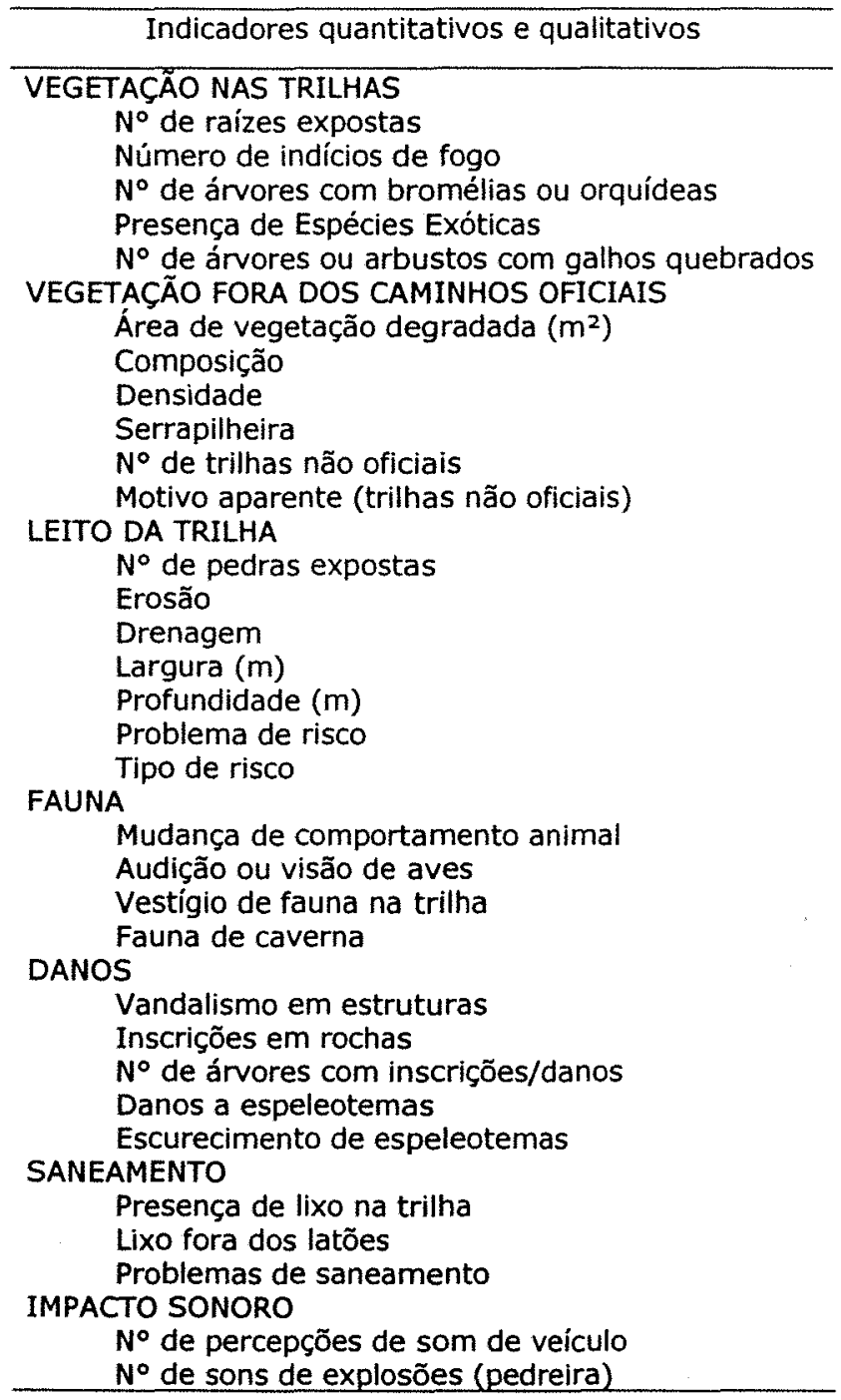

A forma de medição utilizada é uma combinação entre dois métodos de avaliação de múltiplos parâmetros, descritos por Hammit \& Cole (1998). Estes mesmos autores ressaltam que a utilização de um método que inclua medições quantitativas e também medições rápidas baseadas em classes (avaliação qualitativa), é uma alternativa adequada, tendo em vista que agrega precisão e rapidez.

Apesar da efetividade dos indicadores ter sido discutida em seminário com pesquisadores que desenvolvem trabalhos no PEI, as adaptações sugeridas não 
foram utilizadas na segunda avaliação, feita no ano de 2001. Foi utilizada a ficha de campo de 1999 (Anexo A1), para viabilizar a avaliação comparativa das respostas dos indicadores às estratégias de manejo implementadas.

Existem características desejáveis para os indicadores, dentre os quais citase a confiabilidade, que pode ser avaliada com a seguinte questão: $O$ indicador reage positivamente ao manejo, detectando mudanças nas condições do local?

A descrição a seguir explica como cada indicador, tanto quantitativo, como qualitativo foi medido, e as classes utilizadas para alguns indicadores qualitativos.

\subsubsection{Indicadores de vegetação nas trilhas}

Indicador 1 - Número de raízes expostas: Parado no ponto de amostragem, contar o número de raízes expostas, até ao máximo alcance visual em ambas as direções da trilha.

Indicador 2 - Número de indícios de fogo: Contar o número de pontos com vestígios de fogueira.

Indicador 3 - Número de árvores com bromélias ou orquideas: No ponto de amostragem, num ângulo de $360^{\circ}$ contar o número de árvores com bromélias ou orquídeas até ao máximo alcance visual.

Indicador 4 - Presença de espécies exóticas: Registrar a presença ou ausência de espécies exóticas. O registro do nome da planta encontrada é desejável mas não obrigatório, pois depende da identificação da espécie, mesmo que à nível de gênero ou nome popular.

Indicador 5 - Número de árvores ou arbustos com galhos quebrados: Sem sair do ponto de amostragem, contar o número de árvores com galhos qưebrados por vandalismo. Neste caso, não devem ser incluídos galhos cortados no serviço de manutenção das trilhas, ainda que porventura estejam visiveis. Quando possivel, deve-se confirmar a situação encontrada com os monitores, guias ou condutores da área. Os galhos de árvores e arbustos fazem parte da dieta alimentar de diversas 
espécies, principalmente representantes da mastofauna. No Parque Estadual Intervales verificou-se galhos quebrados por anta (Tapirus terrestris).

\subsubsection{Indicadores de vegetação fora dos caminhos oficiais}

Indicador 6 - Área de vegetação degradada: Identificar se a área é caracterizada como área degradada, ou seja onde ainda há presença de vegetação, ou se a área é de solo nu. A área é então medida, selecionando-se uma das formas mais adequadas para representá-la (1=retângulo, 2=triângulo, 3=círculo) para inclusão no cálculo de área, que poderá ser feito em escritório, representado em metros quadrados $\left(\mathrm{m}^{2}\right)$.

Indicador 7 - Composição: Somente quando a área for caracterizada como área degradada. Deve-se comparar a composição da vegetação desta área com a área de referência, ou seja, não degradada mais próxima, utilizando-se: 1=igual ao redor, 2 =diferente, $3=$ muito diferente.

Indicador 8 - Densidade: Somente quando a área for caracterizada como área degradada. Deve-se comparar a densidade da vegetação desta área com a área de referência, ou seja, não degradada mais próxima, utilizando-se: 1=igual ao redor, $2=$ menos denso, $3=$ muito menos denso.

Indicador 9 - Serrapilheira: Somente quando a área for caracterizada como área degradada. Deve-se comparar a aparência da serrapilheira desta área com a área de referência, ou seja, não degradada mais próxima, utilizando-se: $1=$ não pisoteado, 2 =pisoteado, $3=$ ausente.

Indicador 10 - Número de trilhas não oficiais: Contar o número de caminhos ou atalhos que não fazem parte do caminho principal. Sempre deve ser registrado o motivo aparente ou causa da existência de cada um destes caminhos, utilizando: $1=$ água, 2=banheiro, 3=corte de caminho, 4=outros. 


\subsubsection{Indicadores de leito da trilha}

Indicador 11 - Número de pedras expostas: Parado no ponto de amostragem, contar o número de pedras expostas, até ao máximo alcance visual em ambas as direções da trilha.

Indicador 12 - Erosão: Registrar a presença de erosão no ponto de amostragem, utilizando: 1=erosão lateral (Figura 3), 2=erosão em sulco, 3=erosão em canal (Figura 4).

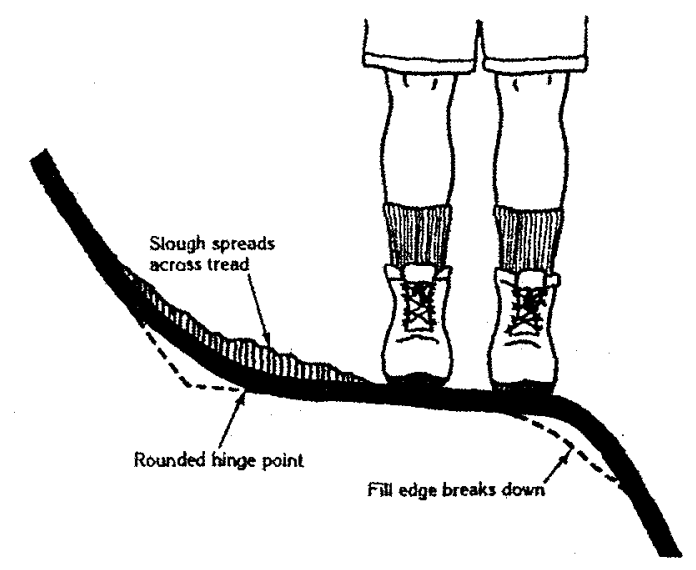

Figura 3- Erosão lateral ao sentido de caminhamento da trilha. Fonte: Hesselbarth \& Vachowski, 1997)

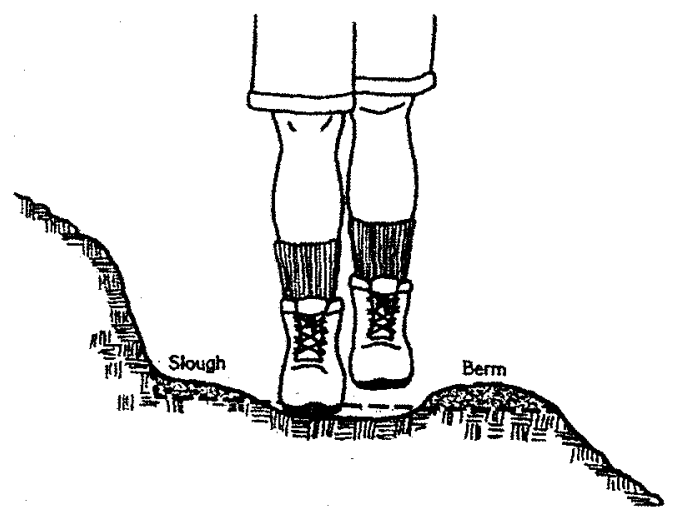

Figura 4 - Erosão em canal, acompanhando o leito da trilha. Fonte: Hesselbarth \& Vachowski, 1997) 
Indicador 13 - Problema de drenagem: Registrar a presença ou ausência de problema de drenagem, como poças d'água, locais com lama.

Indicador 14 - Largura: Com uma trena, medir a largura da trilha, sendo considerado apenas o local marcado pelo pisoteio, sem contar a área adjacente, modificada quando da manutenção do caminho, através do corte da vegetação.

Indicador 15 - Profundidade: Quando verificada a erosão em canal, deve-se medir a profundidade da trilha, em centímetros $(\mathrm{cm})$.

Indicador 16 - Risco: Registrar a presença ou ausência de riscos aos usuários da trilha. Sempre deve ser anotado o tipo de risco ao visitante, sendo: 1=escorregar, $2=$ fatal, $3=$ outros.

\subsubsection{Indicadores de fauna}

Indicador 17 - Mudança de comportamento animal: Registrar a presença ou ausência de mudanças no comportamento normal da fauna. Como exemplo, cita-se - comportamento observado em quatis no Parque Nacional do Iguaçu, que se aproximam dos turistas por interesse em produtos alimentícios variados. Outro exemplo, a aproximação atípica de aves, que vêem em busca de alimento na base do Pico das Agulhas Negras, no Parque Nacional do Itatiaia, e a aproximação de lobo-guará no Parque Nacional da Serra da Canastra. Sempre deve ser registrado o tipo de comportamento atípico observado.

Indicador 18 - Audição ou visão de aves: Registrar a presença ou ausência de vocalização de aves ou visão.

Indicador 19 - Vestígio de fauna: Registrar a presença de vestígios ou a presençca de fauna, utilizando: 1 =pegadas, 2 =carreiro, $3=$ toca, 4 =fezes, 5=ossos, $6=$ cheiro, $7=$ visão ou audição. 
Indicador 20 - Fauna de caverna: Se for realizado levantamento em gruta, registrase a presença de vestígios ou de fauna, utilizando: 1 =pegadas, 2 =carreiro, 3 =toca, $4=$ fezes, $5=$ ossos, $6=$ cheiro, $7=$ visão ou audição.

\subsubsection{Indicadores de danos}

Indicador 21 - Vandalismo em estruturas: Registrar a presença de danos em estruturas provocado por atos de vandalismo, como roubo e danificação de placas, danos em bancos, escadas, corrimão.

Indicador 22 - Inscrições em rochas: Registrar a presença de inscrições em rochas, como nomes de pessoas e desenhos. Facilmente identificáveis nos locais onde ficam localizados os atrativos, como em entrada de gruta.

Indicador 23 - Número de árvores com danos ou inscrições: Contar o número de árvores que apresentam inscrições, como nomes de pessoas escrito na casca da árvore.

Indicador 24 - Danos a espeleotemas: Se for realizado levantamento em gruta, registrar o número de espeleotemas (flores de aragonita, estalactites, estalagmites, represas de travertino) danificados.

Indicador 25 - Escurecimento de espeleotemas: Se for realizado levantamento em gruta, registrar o número de espeleotemas com escurecimento causado pela chama do gás lançado pelo carbureto, utilizado nas carreteiras para iluminação da caverna.

\subsubsection{Indicadores de saneamento}

Indicador 26 - Lixo na trilha: Registrar a presença de lixo visível do ponto de amostragem, utilizando: 1 =pouco, 2 =muito. 
Indicador 27 - Lixo fora dos latões: Se houver latão para recolhimento, registrar a condição em que se encontra o lixo, utilizando: 1=pouco espalhado, 2 =muito espalhado.

Indicador 28 - Problemas de saneamento: Registrar a presença de problemas de saneamento, utilizando: 1 =dejeto, 2 =urina, 3 =fossa ou esgoto, $4=$ =ntulho.

\subsubsection{Indicadores de impacto sonoro}

Indicador 29 - Número de percepções de sons de veículo: Contar o número de vezes em que se ouviu som de veículo no ponto de amostragem.

Indicador 30 - Número de sons de explosões da pedreira: Contar o número de vezes em que se ouviu som de explosão da pedreira próxima ao parque no ponto de amostragem.

\subsection{Avaliação de indicadores através de critérios de qualidade}

Com objetivo de avaliar os indicadores utilizados no monitoramento do uso público, foi realizado um seminário, que contou com a participação de pesquisadores que desenvolvem projetos em áreas específicas no parque. A Fundação Florestal previa para o ano 2000 a realização de um evento com os pesquisadores, e assim foram organizados simultaneamente, o seminário "Efetividade dos indicadores de impacto da visitação no Parque Estadual Intervales", e o III Simpósio sobre Pesquisa Científica, entre 5 e 7 de maio de 2000.

Foram convidados pesquisadores diretamente envolvidos com o parque e técnicos da Secretaria do Meio Ambiente (SMA), envolvidos com o tema "Gestão de Unidades de Conservação". O grupo final de participantes contou com pesquisadores em pleno desenvolvimento de seus projetos, dos que já os concluíram, de orientadores, dos que pretendem desenvolver projetos em Intervales, além de técnicos da SMA, num total de 23 participantes.

Todos os critérios de avaliação selecionados seguiram as características apresentadas por Graefe et al. (1990), cujos indicadores mais efetivos incluem aqueles que são diretamente observados, relativamente fáceis de medir, 
relacionados aos objetivos de manejo da área, sensiveis à mudanças nas condições do uso e passíveis de manejo.

Foram apresentadas as etapas do método VIM, explicando-se as ligações entre as diferentes etapas e como os resultados de cada etapa influenciam na aplicação do método. Os participantes foram divididos em grupos, sendo passada a tarefa através da formulação de uma questão específica: Quais os principais impactos do uso público sobre a vegetação, a fauna, o solo, o ambiente cavernícola, e sobre aspectos sociais?

Depois de terminado o trabalho nos grupos, as fichas com os impactos identificados foram sendo colocadas em um painel. O grupo foi reunido em plenária para estruturação das fichas de acordo com suas similaridades, quando ocorriam repetições, e falta de conexão entre o tema principal e o impacto identificado. Foi apresentada a ficha de campo atualmente utilizada para o levantamento de impactos do uso público. O levantamento foi realizado na trilha da Cachoeira do Mirante. As equipes receberam pranchetas e trenas, e o preenchimento da ficha foi individual. A experiência com o levantamento foi apresentada e discutida em plenária. Na fase final, os indicadores foram avaliados pelos participantes, de acordo com os cinco critérios apontados por Graefe et al. (1990), através de questionários preenchidos individualmente.

\subsubsection{Seleção dos indicadores}

Para proceder a hierarquia dos indicadores elaborou-se uma matriz de avaliação, cujos critérios, utilizados no estudo apresentado por Belnap (1998), incluem características necessárias e desejáveis. Os critérios necessários, considerados os mais importantes, incluem a necessidade do indicador ser: 1) Relacionado aos objetivos da área,; 2) Relacionado ao uso público; e 3) Responde ao manejo. Os critérios com características desejáveis são: 1) Diretamente observável e 2) Fácil de medir. A cada critério foi atribuída uma nota, variando de 0 a 2, para cada um dos critérios escolhidos, com a seguinte escala: $0=0$ critério estabelecido não se aplicada ao indicador; $1=0$ critério estabelecido aplica-se parcialmente ao indicador; e $2=0$ critério estabelecido aplica-se plenamente ao indicador. 


\section{5 Avaliadores diferentes coletam a mesma informação?}

O levantamento foi realizado em quatro trilhas, utilizando-se o método de amostragem de pontos, com espaçamento entre pontos correspondente à extensão da trilha. As avaliações contaram com a participação de 9 avaliadores, sendo 4 no grupo de monitores e 5 no grupo de técnicos. A Figura 5 mostra a distribuição e quantidade de pontos amostrais ao longo das trilhas.
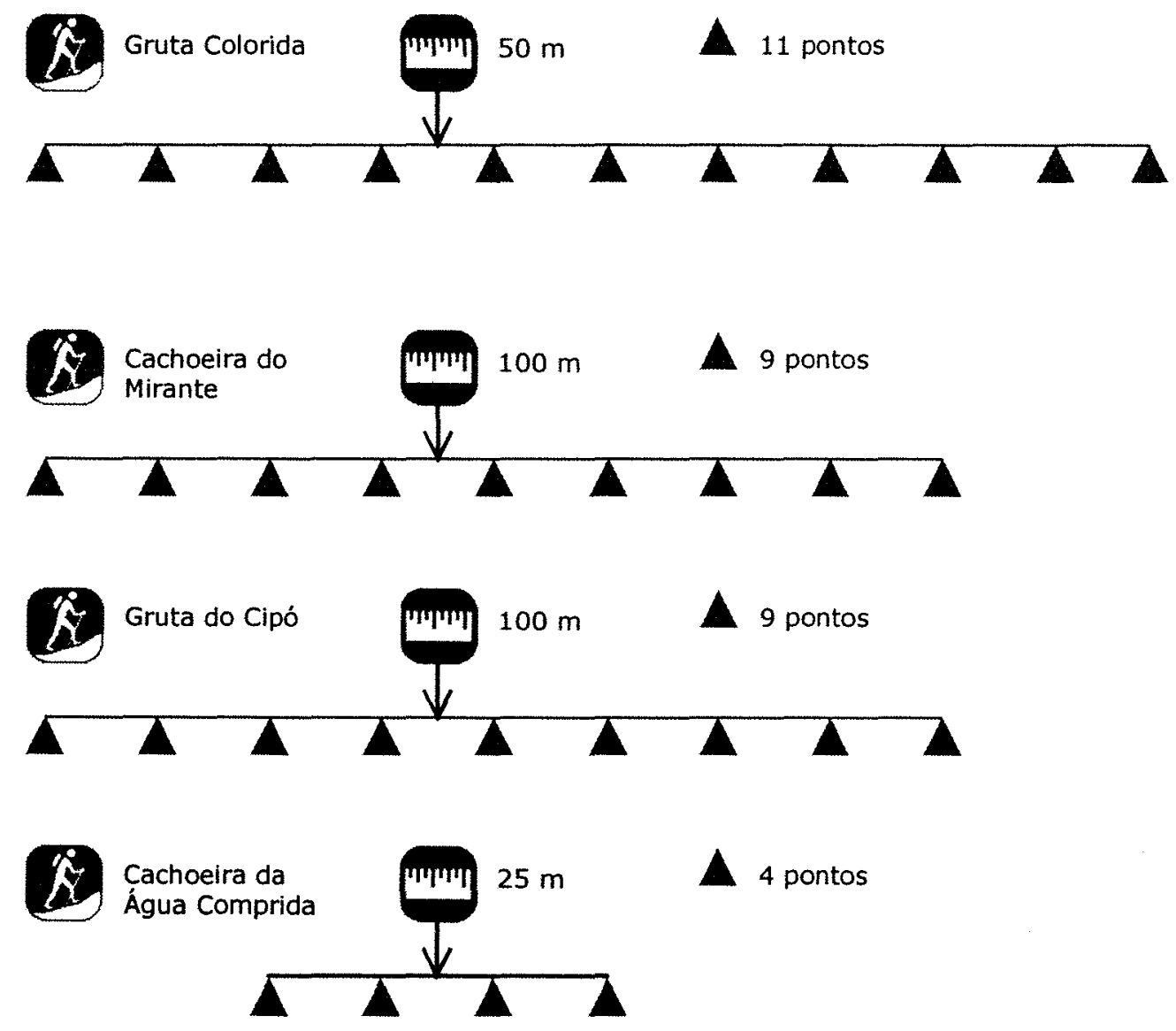

4 pontos

Cachoeira da

(1) Trilha

"'in'il Distância entre pontos

Número de pontos

Figura 5 - Distribuição e quantidade de pontos amostrados em quatro trilhas. 
Os locais de avaliação foram selecionados em função da extensão total das trilhas e da classificação de uso, com trilhas de uso baixo, moderado e alto. A amostragem foi realizada nas trilhas de acesso à Gruta do Cipó, Gruta Colorida, Cachoeira do Mirante e Cachoeira da Água Comprida, com espaçamento entre amostras de $100 \mathrm{~m}, 50 \mathrm{~m}, 100 \mathrm{~m}$, e $25 \mathrm{~m}$ respectivamente, de acordo com o tamanho da trilha.

Na análise comparativa, foram considerados todos os pontos amostrais das trilhas Gruta do Cipó (430m), Gruta Colorida (474m), Cachoeira do Mirante (800) e Cachoeira da Água Comprida $(120 \mathrm{~m})$, como um único conjunto de dados, totalizando $1.824 \mathrm{~m}$ avaliados e 33 pontos. Para localização dos pontos na trilha foi utilizado o instrumento de medição modelo DigiRoller Plus II Digital, com sistema de auto-contagem entre pontos.

Os testes estatísticos podem ser divididos em dois grandes grupos (paramétricos e não paramétricos), conforme fundamentem ou não os seus cálculos, na premissa de que a distribuição de freqüência dos erros amostrais é normal, as variâncias são homogêneas, os efeitos dos fatores de variação são aditivos e os erros independentes (Mann, 1995).

O primeiro passo foi verificar a distribuição das variáveis, para definição do teste a ser empregado, ou seja, paramétrico ou não paramétrico. Para a utilização de um teste paramétrico, as variáveis devem ser amostras aleatórias de populações com distribuição normal, e neste caso, emprega-se o teste t-Student. Neste estudo, utilizou-se o teste não paramétrico Shapiro-Wilk para testar a normalidade dos dados quantitativos.

Para comparação entre os dois grupos, os dados foram analisados por intermédio do teste não paramétrico de Friedman ou teste $G$ para variáveis quantitativas (Zar, 1984) e qui-quadrado para teste de independência ou homogeneidade das variáveis qualitativas (Mann, 1995).

Apesar de avaliados durante os levantamentos, nem todos os indicadores foram registrados em campo, como o indicador indícios de fogo, que consta da ficha, mas não foi presenciado em campo. Assim, a listagem dos indicadores quantitativos e qualitativos registrados durante a avaliação é mostrada nas Tabelas 7 e 8 , respectivamente. 
Tabela 7. Listagem de indicadores quantitativos registrados em campo pelos grupos de avaliadores

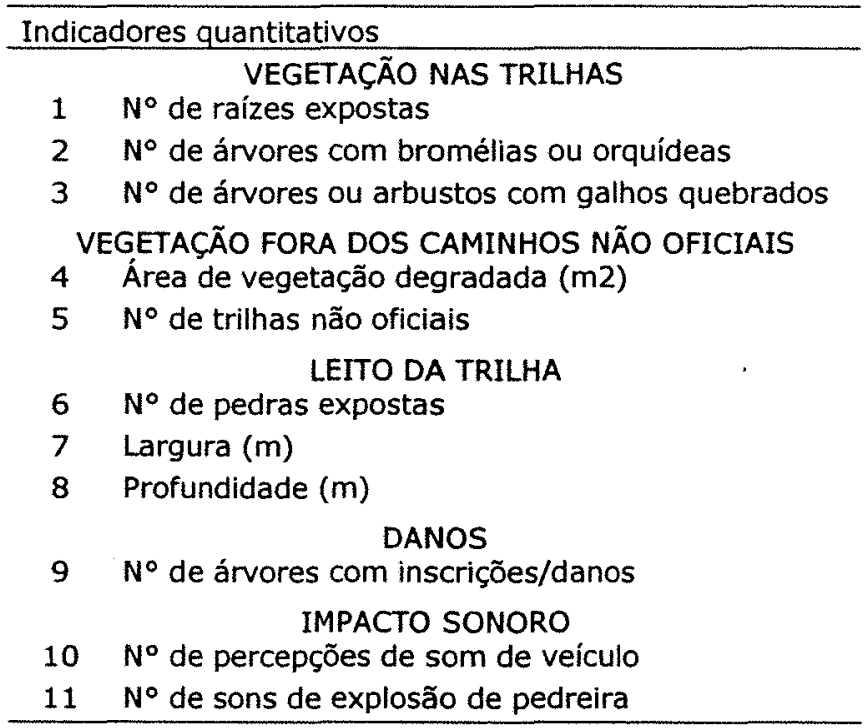

Tabela 8. Listagem de indicadores qualitativos registrados em campo pelos grupos de avaliadores

\begin{tabular}{ll}
\hline Indicadores qualitativos \\
\hline \multicolumn{1}{c}{ VEGETAÇÃO NAS TRILHAS } \\
$12 \quad$ Presença de Espécies Exóticas \\
\multicolumn{2}{c}{ VEGETAÇÃO FORA DOS CAMINHOS NÃO OFICIAIS } \\
$13 \quad$ Composição \\
14 & Densidade \\
15 & Serrapilheira \\
16 & Motivo aparente (trilhas não oficiais) \\
& \multicolumn{1}{c}{ LEITO DA TRILHA } \\
17 & Erosão \\
18 & Drenagem \\
19 & Problema de risco \\
20 & Tipo de risco \\
& \multicolumn{1}{c}{ FAUNA } \\
21 & Audição ou visão de aves \\
22 & Vestígios de fauna \\
& \multicolumn{1}{c}{ DANOS } \\
23 & Vandalismo em estruturas \\
24 & Inscrições em rochas \\
\multicolumn{2}{c}{ SANEAMENTO } \\
25 & Presença de lixo \\
26 & Presença de entulho \\
\hline
\end{tabular}




\section{RESULTADOS E DISCUSSÃO}

\section{1 $O$ indicador reage positivamente ao manejo?}

Os resultados apresentados registram a amplitude dos impactos, avaliados antes da implementação das estratégias de manejo propostas em 1999, e após sua implementação em 2001. Desta forma, são discutidos os indicadores de leito da trilha, diretamente relacionados às ações de manejo implementadas.

Da mesma forma os resultados descritos referem-se aos benefícios ou não da implementação das estratégias de manejo propostas para a recuperação de trilhas no Parque Estadual Intervales. Para avaliar se os indicadores respondem ao manejo, e compará-las à intensidade de uso, foram selecionadas trilhas de alto, moderado e baixo uso que receberam manejo, e trilhas de alto, moderado e baixo uso onde não foram implementadas ações de manejo. A porcentagem de mudança ocorrida entre 1999 e 2001, com a implementação ou não de ações de manejo nas trilhas de uso intensivo, é mostrada na Tabela 9.

Tabela 9. Valores e porcentagens de mudança para indicadores avaliados em trilhas de uso intensivo.

\begin{tabular}{|c|c|c|c|c|c|c|}
\hline \multirow[b]{2}{*}{ Indicadores } & \multicolumn{3}{|c|}{$\begin{array}{l}\text { Trilha com manejo } \\
\text { Gruta Colorida }\end{array}$} & \multicolumn{3}{|c|}{$\begin{array}{l}\text { Trilha sem manejo } \\
\text { Gruta dos Paiva }\end{array}$} \\
\hline & 1999 & 2001 & $\%$ mudanca & 1999 & 2001 & $\%$ mudanca \\
\hline$\%$ de pedras expostas & 0 & 0 & 0 & 0 & 0 & 0 \\
\hline \% de erosão & 47 & 56 & -17 & 50 & 90 & -80 \\
\hline$\%$ de problema de drenagem & 89 & 0 & 100 & 80 & 10 & 88 \\
\hline$\%$ de riscos & 11 & 6 & 47 & 90 & 40 & 56 \\
\hline Largura média da trilha $(\mathrm{m})$ & 2.32 & 0.74 & 70 & 1.7 & 1.2 & 30 \\
\hline Profundidade total $(\mathrm{m})$ & 0.59 & 0.41 & 31 & 0.32 & 0.54 & -69 \\
\hline
\end{tabular}

a Porcentagem de mudança é calculada pelo valor de 1999 menos o valor de 2001 dividido pelo valor de 1999, multiplicado por 100 . 
Os valores de mudança (\%) que apresentaram sinal negativo, destacados em negrito na tabela, indicam que houve degradação das condições do leito da trilha, conforme demonstrado na Figura 6 . Foi considerado que houve mudança nos indicadores se o valor do indicador em 2001 apresentou diferença de $10 \%$ em relação ao valor encontrado em 1999, segundo classificação apresentada por Spildie et al. (2000).

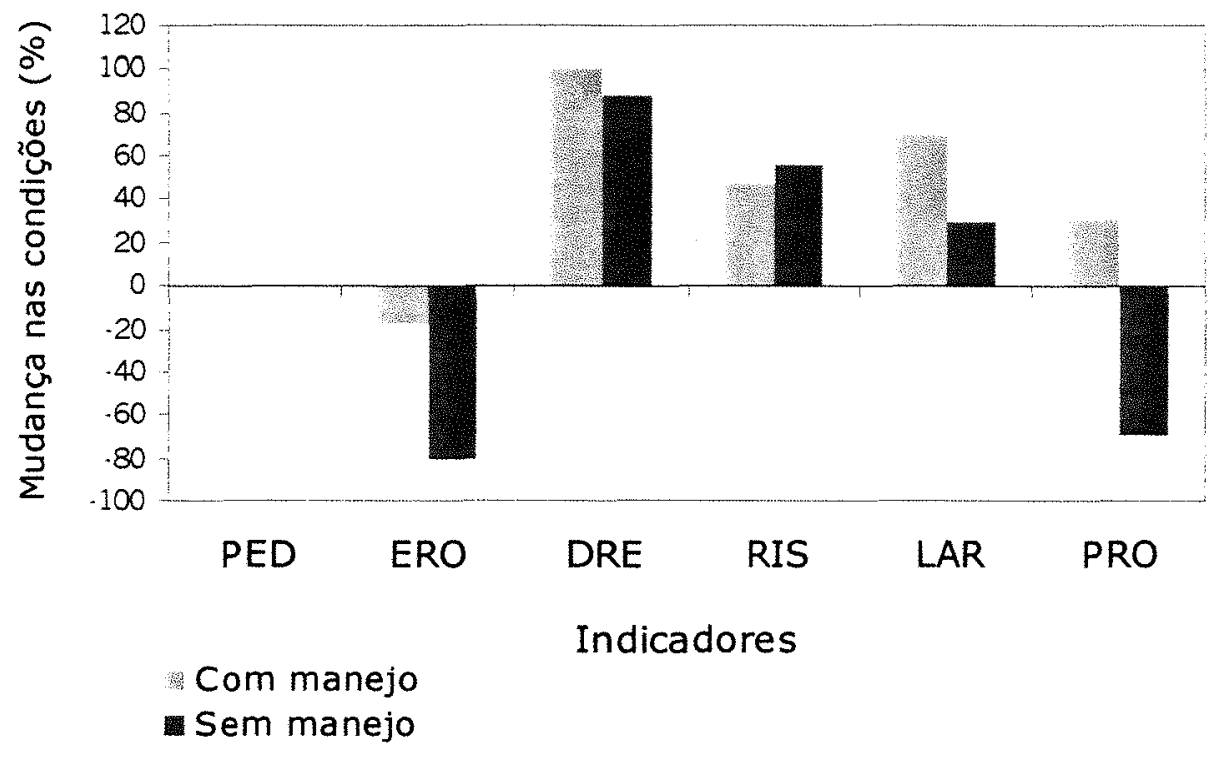
$P E D=$ número de pedras expostas
RIS $=$ risco de acidente
LAR=largura $E R O=$ erosão
DRE $=$ problema de drenagem
$\mathrm{PRO}=$ profundidade

Figura 6 - Porcentagem de mudança dos indicadores de leito, para trilhas de uso intensivo com e sem manejo implementado.

Todos os indicadores nas trilhas com e sem manejo, apresentaram mudança nas condições, de acordo com a classificação de Spildie et al. (2000), com exceção do número de pedras expostas. A erosão na trilha aumentou nas duas condições de manejo, apesar de ser menos pronunciada na trilha com manejo $(-17 \%)$ em comparação com a trilha sem manejo $(-80 \%)$. Isto reforça que, mesmo com ações de manejo implementadas, micro erosões ao longo de todo o sistema de trilhas, sempre estarão presentes, conforme apontado por Hesselbarth \& Vachowski (1997). A porcentagem de mudança para o indicador profundidade foi de $-69 \%$ na trilha 
sem manejo, significando que durante o período de dois anos houve um aumento de $69 \%$ na profundidade do leito. Os valores de profundidade apresentados representam a soma total dos pontos avaliados, que variam entre 0,03 e 0,14m por ponto. A profundidade da trilha está associada à compactação pelo pisoteio, erosão e outros problemas como a drenagem. Se não forem implementadas ações para minimizar o impacto negativo sobre o leito, é possível que em avaliações futuras, estes valores venham a aumentar. Assim, apesar do indicador profundidade apresentar boa resposta ao manejo, sua relação causa-efeito necessita de maior estudo. O mesmo se aplica aos indicadores erosão, problema de drenagem e largura da trilha.

Magro (1999) aponta que os indicadores que tem maior relação com os impactos são a declividade, textura e a área de seção transversal. A área de seção transversal é uma medida completa da erosão ocorrida na trilha, e inclui medição da largura e profundidade em diversos pontos. Apesar de ser uma medida completa, este indicador não vem sendo utilizado em programas de monitoramento, que buscam indicadores simples e rápidos.

Os problemas de drenagem e risco diminuíram em relação ao primeiro levantamento. Este resultado pode ter sido influenciado pelas condições climáticas, pois ambos os indicadores estão associados. Se houver problema de drenagem, muito provavelmente haverá riscos de o visitante escorregar na trilha. Na trilha de acesso à Gruta Colorida, os problemas de drenagem e risco também podem ter diminuído em função do manejo implementado.

A diminuição na largura da trilha com manejo pode ser considerada a mudança mais representativa de todos os indicadores comparados, mostrando que indicadores qualitativos são mais confiáveis. A ação de manejo implementada na trilha da Gruta Colorida foi o estreitamento de trilhas, juntamente com a correção do leito, mudança de traçado e construção de canais de drenagem. Já para a diminuição na largura da trilha sem manejo, pode ter ocorrido um maior cuidado na roçada da trilha, uma vez em 1999 foi apontado o corte exagerado da vegetação.

Os valores de mudança alcançados nas trilhas de uso moderado são mostrados na Tabela 10. Para as trilhas de uso moderado, apenas na trilha sem manejo os indicadores erosão e profundidade apresentaram mudanças negativas nas condições. Também não foram detectadas mudanças para o indicador pedras expostas nas duas condições de manejo. 
Tabela 10. Valores e porcentagens de mudança a para indicadores avaliados em trilhas de uso moderado.

\begin{tabular}{|c|c|c|c|c|c|c|}
\hline \multirow[b]{2}{*}{ Indicadores } & \multicolumn{3}{|c|}{$\begin{array}{l}\text { Trilha com manejo } \\
\text { Cachoeira da Água Comprida }\end{array}$} & \multicolumn{3}{|c|}{$\begin{array}{l}\text { Trilha sem manejo } \\
\text { Gruta do Fendão }\end{array}$} \\
\hline & 1999 & 2001 & $\%$ mudança & 1999 & 2001 & $\%$ mudança \\
\hline$\%$ de pedras expostas & 0 & 0 & 0 & 0 & 0 & 0 \\
\hline$\%$ de erosão & 100 & 25 & 75 & 25 & 38 & -50 \\
\hline$\%$ de problema de drenagem & 100 & 0 & 100 & 25 & 25 & 0 \\
\hline$\%$ de riscos & 100 & 0 & 100 & 38 & 38 & 0 \\
\hline Largura média da trilha $(\mathrm{m})$ & 0.65 & 0.62 & 5 & 0.71 & 0.45 & 37 \\
\hline Profundidade total $(\mathrm{m})$ & 0.28 & 0 & 100 & 0.11 & 0.18 & -64 \\
\hline
\end{tabular}

a Porcentagem de mudança é calculada pelo valor de 1999 menos o valor de 2001 dividido pelo valor de 1999, multiplicado por 100 .

Não houve mudanças para o indicador problema de drenagem, na trilha sem manejo. As fendas naturais encontradas no leito rochoso da trilha de acesso à Gruta do Fendão continuam presentes, representando perigo aos visitantes, e portanto não houve mudança no indicador riscos. A grande contribuição da recuperação da trilha de acesso à cachoeira da Água Comprida pode ser observada nos valores de mudança para os indicadores problema de drenagem, riscos e profundidade, com $100 \%$ de mudança nas condições anteriormente verificadas (Figura 7 ).

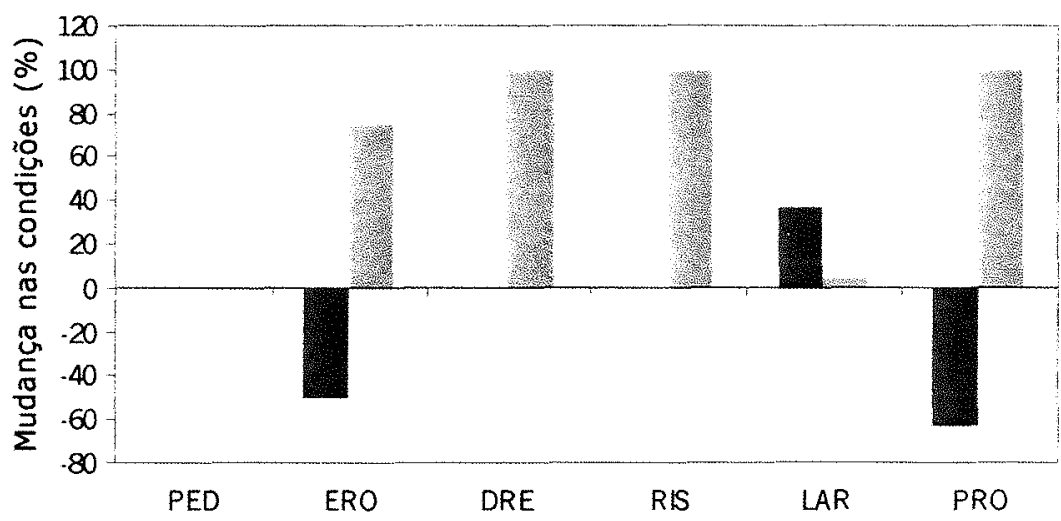

Indicadores

Sem manejo

Com manejo

PED=número de pedras expostas

RIS=risco de acidente

LAR=largura $E R O=$ erosão

Figura 7 - Porcentagem de mudança dos indicadores de leito, para trilhas de uso moderado com e sem manejo implementado. 
Os valores de mudança nas trilhas de baixo uso encontram-se na Tabela 11 , e a comparação entre a trilha com e sem manejo é mostrada na Figura 8.

Tabela 11. Valores e porcentagens de mudançaa para indicadores avaliados em trilhas de baixo uso.

\begin{tabular}{|c|c|c|c|c|c|c|}
\hline \multirow{2}{*}{ Indicadores } & \multicolumn{3}{|c|}{$\begin{array}{l}\text { Trilha com manejo } \\
\text { Gruta do Minotauro }\end{array}$} & \multicolumn{3}{|c|}{$\begin{array}{l}\text { Trilha sem manejo } \\
\text { Cachoeira das Pedrinhas }\end{array}$} \\
\hline & 1999 & 2001 & $\%$ mudanca & 1999 & 2001 & $\%$ mudanca \\
\hline$\%$ de pedras expostas & 0 & 0 & 0 & 0 & 0 & 0 \\
\hline \% de erosão & 89 & 50 & 44 & 22 & 13 & 44 \\
\hline$\%$ de problema de drenagem & 100 & 13 & 88 & 11 & 13 & -13 \\
\hline$\%$ de riscos & 0 & 0 & 0 & 67 & 11 & 83 \\
\hline Largura média da trilha $(\mathrm{m})$ & 2.08 & 0.84 & 64 & 1.19 & 0.49 & 59 \\
\hline Profundidade total $(m)$ & 0.41 & 0.07 & 83 & 0 & 0 & 0 \\
\hline
\end{tabular}

a Porcentagem de mudança é calculada pelo valor de 1999 menos o valor de 2001 dividido pelo valor de 1999, multiplicado por 100 .

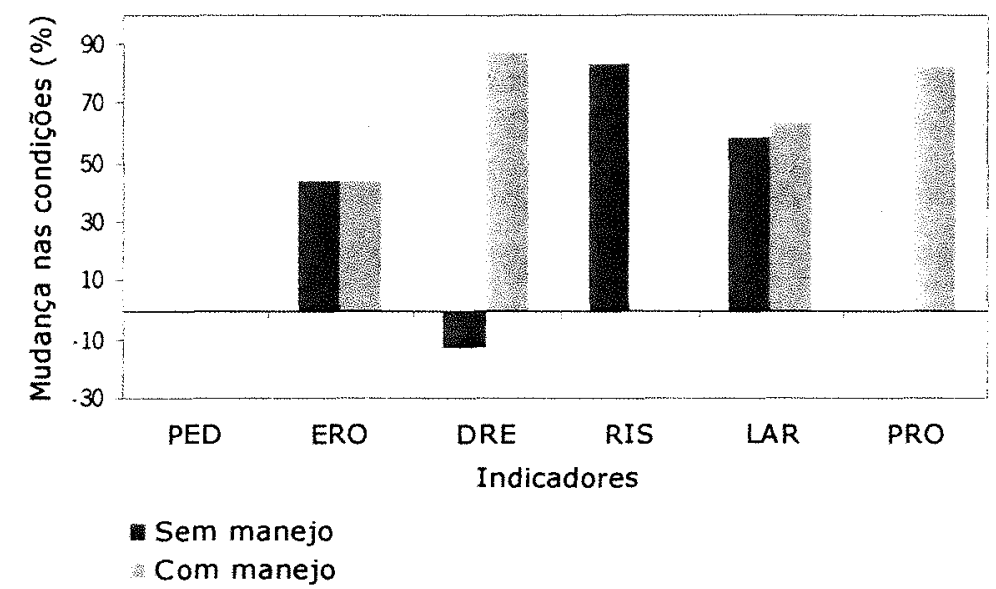

PED=número de pedras expostas ERO=erosão
RIS $=$ risco de acidente
LAR=largura
DRE = problema de drenagem
$\mathrm{PRO}=$ profundidade

Figura 8 - Porcentagem de mudança dos indicadores de leito para trilhas de baixo uso com e sem manejo implementado.

Nas trilhas de baixo uso, novamente o indicador número de pedras expostas não apresentou mudança. Assim, também a profundidade não apresentou mudança 
na trilha de acesso à Cachoeira das Pedrinhas, onde este problema não foi registrado em nenhum ponto. Nesta trilha, o aumento no problema de drenagem $(13 \%)$ pode ter ocorrido devido às condições climáticas no momento do registro e também às condições ecológicas do local. A área apresenta características de solos úmidos e pobres, com presença de bacias geológicas, áreas encharcadas, e uma enorme quantidade de raízes expostas. Assim, o problema de drenagem é também um indicador da fragilidade da área sob o ponto de vista do manejo.

$\mathrm{Na}$ trilha da Gruta do Minotauro a mudança no indicador drenagem pode ter ocorrido devido à condição climática presente no período da avaliação, pois medidas de contenção da água das chuvas, como barreiras de desvio e canais de drenagem não eram necessárias de acordo como levantamento de 1999. No entanto, medidas para conter a erosão responderam ao manejo implementado. Próximo à entrada da gruta foi implementada uma escada com pedras naturais, onde anteriormente existia um barranco não mais encoberto pela vegetação.

\subsection{Avaliação de indicadores através de critérios de qualidade}

Durante o processo de sistematização verificou-se que muitas contribuições discutidas entre os grupos temáticos, como a vegetação, fauna, solo, ambiente cavernícola, e aspectos sociais não eram de fato indicadores, mas características de impactos específicos ou um indicador potencial (Anexo A2).

Os indicadores foram avaliados por 23 pesquisadores, através do preenchimento individual das fichas de avaliação, totalizando $86 \%$ de questões respondidas e $14 \%$ não respondidas, como apresentado na Tabela 12.

Tabela 12. Total de respostas obtidas na avaliação dos indicadores

\begin{tabular}{lcc}
\hline Grupo de indicadores & $\begin{array}{c}\text { Questões } \\
\text { respondidas }\end{array}$ & $\begin{array}{c}\text { Questões não } \\
\text { respondidas }\end{array}$ \\
\hline Vegetação nas trilhas & 508 & 67 \\
Vegetação fora dos caminhos oficiais & 531 & 59 \\
Leițo da trilha & 593 & 97 \\
Fauna & 373 & 87 \\
Danos & 289 & 56 \\
Saneamento & 285 & 60 \\
Impacto sonoro & 92 & 23 \\
TOTAL & 2671 & 449 \\
\hline
\end{tabular}


Observou-se que alguns indicadores deixaram de ser analisados pelos pesquisadores, o que se atribuiu à dificuldade em avaliá-los segundo os critérios estabelecidos. As notas atribuídas aos indicadores, de acordo com os critérios de qualidade, são demostrados na Tabela 13.

Tabela 13. Indicadores que se aplicam plenamente aos critérios estabelecidos

\begin{tabular}{|c|c|c|c|c|c|}
\hline \multirow[b]{3}{*}{ Indicadores avaliados } & \multicolumn{5}{|c|}{$\begin{array}{l}\text { Critérios presentes em bons indicadores } \\
\text { (Graefe, 1990) }\end{array}$} \\
\hline & \multicolumn{3}{|c|}{ NECESSARIOS } & \multicolumn{2}{|c|}{ DESEJÁVEIS } \\
\hline & $\begin{array}{c}\text { Relacionado } \\
\text { aos objetivos } \\
\text { da área }\end{array}$ & $\begin{array}{l}\text { Relacionado } \\
\text { ao uso } \\
\text { público } \\
\end{array}$ & $\begin{array}{l}\text { Responde } \\
\text { ao manejo }\end{array}$ & $\begin{array}{l}\text { Diretamente } \\
\text { observável }\end{array}$ & $\begin{array}{l}\text { Fácil de } \\
\text { medir }\end{array}$ \\
\hline$N^{\circ}$ de raízes expostas & 1 & 1 & 1 & 2 & 2 \\
\hline$N^{\circ}$ de indícios de fogo & 2 & 2 & 2 & 2 & 2 \\
\hline$N^{\circ}$ de árvores com bromélias ou orquídeas & 2 & 1 & 1 & 2 & 2 \\
\hline Presença de espécies exóticas & 2 & 2 & 2 & 0 & 0 \\
\hline $\begin{array}{l}N^{\circ} \text { de árvores ou arbustos com galhos } \\
\text { quebrados }\end{array}$ & 1 & 2 & 1 & 1 & 2 \\
\hline Área de solo nu & 2 & 2 & 2 & 2 & 2 \\
\hline Área de vegetação degradada & 2 & 2 & 2 & 1 & 1 \\
\hline Composição & 2 & 2 & 1 & 1 & $i$ \\
\hline Densidade & 2 & 2 & 2 & 1 & 1 \\
\hline Serrapilheira & 2 & 2 & 1 & 2 & 2 \\
\hline$N^{\circ}$ de trilhas não oficiais & 2 & 2 & 2 & 2 & 2 \\
\hline Motivo aparente & 1 & $\overline{2}$ & $\overline{2}$ & 1 & 1 \\
\hline Erosão & 2 & $\overline{2}$ & 2 & 2 & 2 \\
\hline Problemas de drenagem & 2 & 2 & 2 & 2 & 1 \\
\hline Largura & 2 & 2 & 1 & 2 & 2 \\
\hline Profundidade & 2 & 2 & 2 & 1 & 2 \\
\hline Problemas de risco & 2 & 1 & 2 & 2 & 1 \\
\hline Tipo de risco & 2 & 1 & 2 & 2 & 1 \\
\hline Mudança de comportamento animal & 2 & 2 & 0 & 0 & 0 \\
\hline Visão ou audição de aves & 2 & 2 & 0 & 2 & 1 \\
\hline Vestígios de fauna na trilha & 2 & 2 & 0 & 1 & 1 \\
\hline Fauna de caverna & 2 & 2 & 0 & 2 & 1 \\
\hline Vandalismo em estruturas & 2 & 2 & 2 & 2 & 2 \\
\hline Inscrições em rochas & 2 & 2 & 2 & 2 & 2 \\
\hline$N^{\circ}$ de árvores com danos ou inscrições & 2 & 2 & 2 & 2 & 2 \\
\hline Lixo na trilha & 2 & 2 & 2 & 2 & 2 \\
\hline Lixo fora dos latões & 2 & 2 & 2 & 2 & 2 \\
\hline Problemas de saneamento & 2 & 2 & 2 & 2 & 2 \\
\hline$N^{0}$ de percepcões de sons de veículo & 2 & 2 & 2 & 2 & 2 \\
\hline
\end{tabular}

$0=$ critério estabelecido năo se aplicada ao indicador

$1=$ critério estabelecido aplica-se parcialmente ao indicador

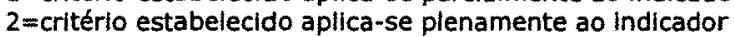

Os valores das colunas correspondem à maior frequência do critério designado para avaliação dos indicadores. Seguindo a metodologia de seleção de indicadores apresentada por Belnap (1998), foi elaborada uma matriz para avaliação dos indicadores através dos critérios (Tabela 14). Foram considerados bons indicadores aqueles que apresentaram os três critérios considerados necessários. 
Tabela 14. Matriz de avaliação para seleção de indicadores que se aplicam plenamente aos critérios estabelecidos

\begin{tabular}{|c|c|c|c|c|c|}
\hline \multirow[b]{3}{*}{ Indicadores avaliados } & \multicolumn{5}{|c|}{$\begin{array}{l}\text { Critérios presentes em bons indicadores } \\
\text { (Graefe,1990) }\end{array}$} \\
\hline & \multicolumn{3}{|c|}{ NECESSÁRIOS } & \multicolumn{2}{|c|}{ DESEJÁVEIS } \\
\hline & $\begin{array}{l}\text { Relacionado } \\
\text { aos objetivos } \\
\text { da área }\end{array}$ & $\begin{array}{l}\text { Relacionado } \\
\text { ao uso } \\
\text { públlco }\end{array}$ & $\begin{array}{l}\text { Responde } \\
\text { ao manejo }\end{array}$ & $\begin{array}{l}\text { Diretamente } \\
\text { observável }\end{array}$ & $\begin{array}{l}\text { Fácil de } \\
\text { medir }\end{array}$ \\
\hline$N^{0}$ de raizes expostas & & & & $x$ & $x$ \\
\hline$N^{\circ}$ de indicios de fogo & $x$ & $x$ & $x$ & $x$ & $x$ \\
\hline$N^{\circ}$ de árvores com bromélias ou orquídeas & $x$ & & & $x$ & $x$ \\
\hline Presença de espécles exóticas & $x$ & $x$ & $x$ & . & \\
\hline $\begin{array}{l}N^{\circ} \text { de árvores ou arbustos com galhos } \\
\text { quebrados }\end{array}$ & & $x$ & & & $\mathrm{x}$ \\
\hline Área de solo nu & $x$ & $\mathrm{x}$ & $x$ & $x$ & $x$ \\
\hline Área de vegetação degradada & $x$ & $x$ & $x$ & & \\
\hline Composição & $x$ & $x$ & & & \\
\hline Densidade & $\mathrm{x}$ & $x$ & $x$ & & \\
\hline Serrapilheira & $x$ & $x$ & & $x$ & $x$ \\
\hline$N^{\circ}$ de trilhas não oficiais & $x$ & $x$ & $x$ & $x$ & $x$ \\
\hline Motivo aparente & & $x$ & $x$ & & \\
\hline Erosão & $x$ & $x$ & $x$ & $x$ & $x$ \\
\hline Problemas de drenagem & $x$ & $x$ & $x$ & $x$ & \\
\hline Largura & $x$ & $x$ & & $x$ & $x$ \\
\hline Profundidade & $x$ & $x$ & $x$ & & $x$ \\
\hline Problemas de risco & $x$ & & $x$ & $x$ & \\
\hline Tipo de risco & $x$ & & $x$ & $x$ & \\
\hline Mudança de comportamento animal & $x$ & $x$ & & & \\
\hline Visão ou audição de aves & $\mathrm{x}$ & $x$ & & $x$ & \\
\hline Vestíglos de fauna na trilha & $x$ & $x$ & & & \\
\hline Fauna de caverna & $x$ & $x$ & & $x$ & \\
\hline Vandalismo em estruturas & $x$ & $x$ & $x$ & $x$ & $x$ \\
\hline Inscrições em rochas & $x$ & $x$ & $x$ & $x$ & $x$ \\
\hline$N^{\circ}$ de árvores com danos ou inscrições & $x$ & $x$ & $x$ & $x$ & $x$ \\
\hline Lixo na trilha & $x$ & $x$ & $x$ & $x$ & $x$ \\
\hline Lixo fora dos latões & $x$ & $x$ & $\mathbf{x}$ & $x$ & $x$ \\
\hline Problemas de saneamento & $x$ & $x$ & $x$ & $x$ & $x$ \\
\hline$N^{\circ}$ de sons de veículo & $x$ & $x$ & $x$ & $x$ & $x$ \\
\hline
\end{tabular}

\subsection{Avaliadores diferentes coletam a mesma informação?}

A estatística paramétrica não pôde ser utilizada para a comparação dos grupos, devido a distribuição assimétrica dos dados apresentados pelas variáveis quantitativas. Assim sendo, no teste de comparação de grupos e indivíduos dentro do mesmo grupo, as variáveis quantitativas não apresentaram normalidade para os testes paramétricos de $t$-Student e não paramétricos de Shapiro-Wilk. 
Portanto, foram utilizados os testes não paramétricos de Friedman para variáveis quantitativas e qui-quadrado para variáveis qualitativas.

Hipótese 1 - Os indicadores não devem ser significativamente diferentes (valor-p maior que 0.05 ) na avaliação realizada entre o grupo de técnicos $e$ monitores.

Os resultados do trabalho mostraram, pelo teste não-paramétrico Friedman ou teste $G(p>0,05)$, e teste da verossimilhança, que não houve diferença estatística entre os grupos para os indicadores: $n^{\circ}$ de raizes expostas, $n^{\circ}$ de árvores com bromélias ou orquídeas, presença de espécies exóticas, $n^{\circ}$ de árvores ou arbustos com galhos quebrados, audição ou visão de aves, vandalismo em estruturas, inscrições em rochas, $n^{\circ}$ de árvores com inscrições ou danos, presença de entulho, $n^{\circ}$ de percepç̃es de som de veículo. Portanto, na avaliação realizada pelos dois grupos, verificou-se que 16 indicadores apresentarám valores significativos e 10 apresentaram valores não significativos (Tabela 15). Os indicadores não significativos ao nivel de $5 \%$ e $1 \%$ de probabilidade foram agrupados.

Tabela 15. Indicadores com valores significativos e não significativos para análise comparativa entre o grupo de monitores e técnicos.

\begin{tabular}{ll}
\hline Indicadores com valor-p significativo $(<0.05)$ & Indicadores com valor-p não significativo $(>0.05)$ \\
\hline 1. Área de vegetação degradada $\left(\mathrm{m}^{2}\right)$ & 1. $\mathrm{N}^{\circ}$ de raízes expostas \\
2. Serrapilheira & 2. $\mathrm{N}^{\circ}$ de árvores com broméllas ou orquideas \\
3. Drenagem & 3. Presença de espécles exóticas \\
4. Presença de lixo & 4. $\mathrm{N}^{\circ}$ de árvores ou arbustos com galhos quebrados \\
5. Composição & 5. Audição ou visão de aves \\
6. Densidade & 6. Vandalismo em estruturas \\
7. No de trilhas não oficlais & 7. Inscrições em rochas \\
8. Motlvo aparente (trilhas não oflcials) & 8. $N^{\circ}$ de árvores com inscrições/danos \\
9. No de pedras expostas & 9. Presença de entulho \\
10. Erosão & 10. No de percepções de som de veículo \\
11. Largura (m) & \\
12. Profundidade (m) & \\
13. Problema de risco & \\
14. Tipo de risco & \\
15. Vestígio de fauna & \\
16. No de sons de explosões (pedrelra) &
\end{tabular}


Hipótese 2: Os indicadores não devem ser significativamente diferentes (valor-p maior que 0.05) na avaliação realizada entre indivíduos do grupo de monitores.

O grupo de monitores foi estatisticamente superior ao grupo de técnicos para os indicadores: presença de espécies exóticas, problemas de drenagem, problemas de risco, tipo de risco, e número de sons de explosões de pedreira. Entre os indivíduos do grupo de monitores foram observados 21 indicadores não significativos contra 5 significativos (Tabela 16).

Tabela 16. Indicadores com valores significativos e não significativos para análise comparativa entre individuos do grupo de monitores.

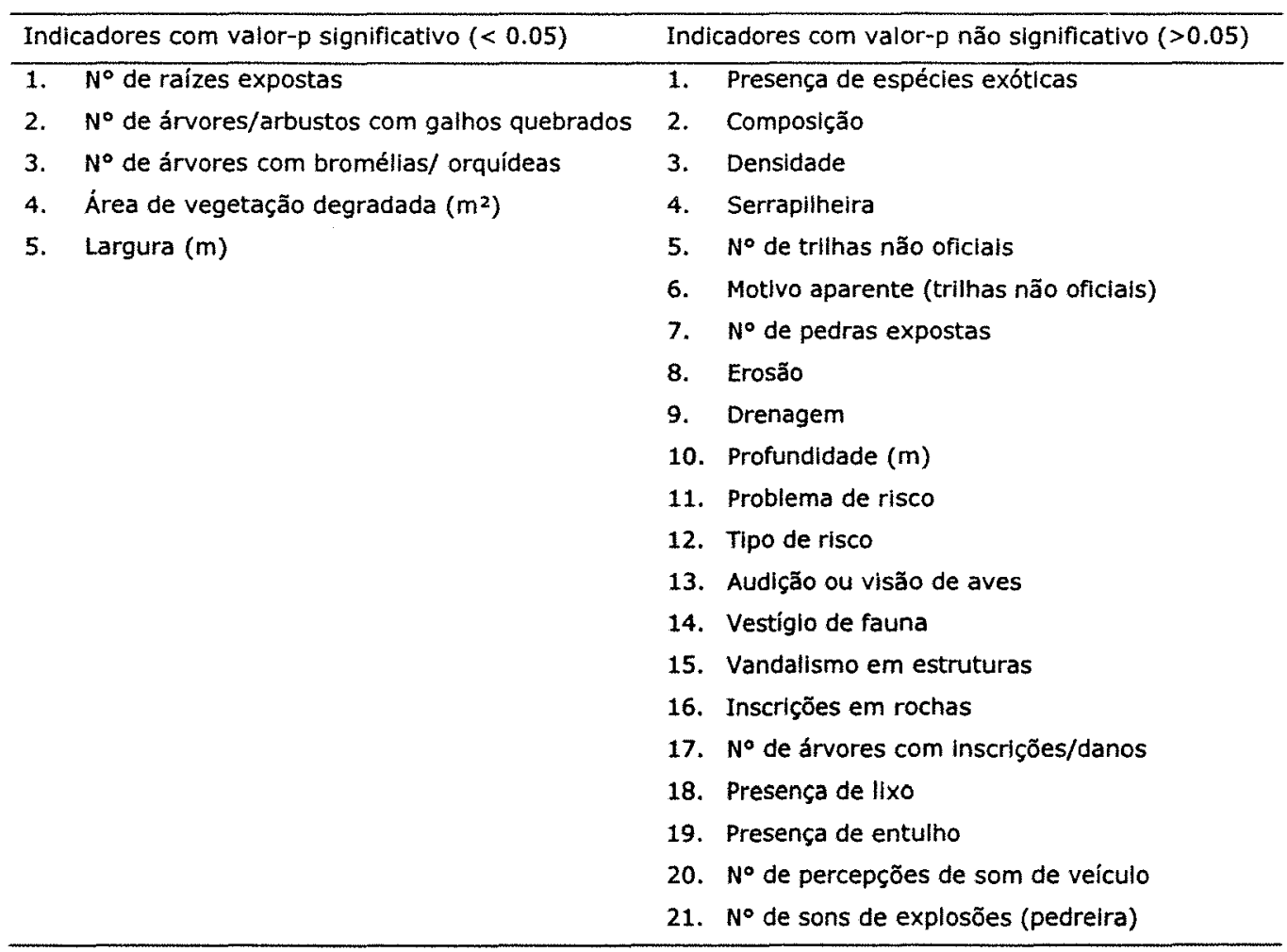

Hipótese 3: Os indicadores não devem ser significativamente diferentes (valor-p maior que 0.05) na avaliação realizada entre indivíduos do grupo de técnicos.

o grupo de técnicos foi significativamente melhor do que o grupo de monitores para os indicadores: número de raizes expostas, área de vegetação degradada, largura e presença de entulho (problemas de saneamento). Entre os 
indivíduos do grupo de técnicos foram observados 19 indicadores não significativos contra 8 significativos (Tabela 17).

Tabela 17. Indicadores com valores significativos e não para análise comparativa entre indivíduos do grupo de técnicos.

\begin{tabular}{|c|c|}
\hline Indicadores com valor-p significativo $(<0.05)$ & Indicadores com valor-p não significativo $(>0.05)$ \\
\hline 1. $N^{\circ}$ de árvores/arbustos com galhos quebrados & 1. $N^{\circ}$ de raízes expostas \\
\hline 2. $\quad N^{\circ}$ de árvores com broméllas/ orquídeas & 2. Área de vegetação degradada $\left(\mathrm{m}^{2}\right)$ \\
\hline 3. Presença de Espécies Exóticas & 3. Composição \\
\hline 4. Drenagem & 4. Densidade \\
\hline 5. Problema de risco & 5. Serrapilheira \\
\hline 6. Tlpo de risco & 6. $N^{\circ}$ de trilhas não oficials \\
\hline \multirow[t]{13}{*}{ 7. $N^{\circ}$ de sons de explosões (pedreira) } & 7. Motivo aparente (trilhas não oficiais) \\
\hline & 8. $N^{\circ}$ de pedras expostas \\
\hline & 9. Erosão \\
\hline & 10. Largura $(m)$ \\
\hline & 11. Profundidade $(\mathrm{m})$ \\
\hline & 12. Audição ou visão de aves \\
\hline & 13. Vestiglo de fauna \\
\hline & 14. Vandalismo em estruturas \\
\hline & 15. Inscrições em rochas \\
\hline & 16. $N^{0}$ de árvores com inscrições/danos \\
\hline & 17. Presença de lixo \\
\hline & 18. Presença de entulho \\
\hline & 19. $N^{\circ}$ de percep̧̧ões de som de veículo \\
\hline
\end{tabular}

Estes resultados sugerem que ao se comparar os dois grupos houve maior homogeneidade na avaliação realizada pelo grupo de monitores.

Porém, um grupo de indicadores não registrados em campo por nenhum indivíduo do grupo de monitores pode ter influenciado esta conclusão. Aparentemente, por se tratar de indicadores difíceis de serem medidos e não diretamente observáveis, como apontado pelos resultados da avaliação do seminário (Tabela 14), pressupõese que deixaram de ser registrados pelo grupo de monitores por estes motivos. Os indicadores não registrados pelo grupo de monitores incluem a composição, densidade, serrapilheira na área de vegetação degradada, número de trilhas não oficiais e motivo aparente.

Os indicaores de leito da trilha e vegetação fora do caminhos oficiais foram significativamente diferentes entre os dois grupos comparados (Tabela 18). 
Tabela 18. Valor-p e nivel de significância na comparação dos indicadores avaliados entre grupos de monitores e técnicos, e indivíduos do mesmo grupo.

\begin{tabular}{|c|c|c|c|c|}
\hline \multirow[b]{2}{*}{ Indicadores quantitativos e qualitativos } & \multirow[b]{2}{*}{ Sigla } & \multicolumn{3}{|c|}{ Valor-p e significância das classes comparadas } \\
\hline & & $\begin{array}{c}\text { ENTRE } \\
\text { GRUPOS }^{a} \\
\end{array}$ & MONTTORES ${ }^{a}$ & TÉCNICOS ${ }^{\mathrm{a}}$ \\
\hline \multicolumn{5}{|l|}{ VEGETAÇÃO NAS TRILHAS } \\
\hline$N^{\circ}$ de raizes expostas & RAI & $0.083(F)$ & $0.021 *(F)$ & $0.891(F)$ \\
\hline$N^{\circ}$ de árvores com bromélias/ orquídeas & BRO & $0.234(F)$ & $<.0001 * *(F)$ & $<.0001 * *(F)$ \\
\hline Presença de Espécies Exóticas & EXO & $0.335(G)$ & $0.658(G)$ & $<.0001 * *(G)$ \\
\hline$N^{\circ}$ de árvores/arbustos com galhos quebrados & GAL & $0.215(F)$ & $0.030 *(F)$ & $0.036 *(F)$ \\
\hline \multicolumn{5}{|l|}{ VEGETAÇÀO FORA DOS CAMINHOS OFICIAIS } \\
\hline Área de vegetação degradada $\left(\mathrm{m}^{2}\right)$ & DEG & $0.024 *(F)$ & $<.0001 * *(F)$ & $0.975(F)$ \\
\hline Composição & COM & $0.004 * *(G)$ & $N R^{b}$ & $0.852(G)$ \\
\hline Densidade & DEN & $0.004 * *(G)$ & $N R^{b}$ & $0.323(G)$ \\
\hline Serrapilheira & SER & $0.012 *(G)$ & $N R^{b}$ & $0.603(G)$ \\
\hline$N^{\circ}$ de trilhas não oficiais & TNO & $0.000 * *(F)$ & $N R^{b}$ & $0.994(F)$ \\
\hline Motivo aparente (trilhas não oficiais) & MOT & $<.0001 * *(\mathrm{G})$ & $N R^{b}$ & $0.915(G)$ \\
\hline \multicolumn{5}{|l|}{ LEITO DA TRILHA } \\
\hline$N^{\circ}$ de pedras expostas & PED & $0.000 * *(F)$ & $0.467(F)$ & $0.133(F)$ \\
\hline Erosão & ERO & $<.0001 * *(G)$ & $0.217(G)$ & $0.079(G)$ \\
\hline Drenagem & DRE & $0.047 *(G)$ & $0.774(G)$ & $<.0001 * *(G)$ \\
\hline Largura $(m)$ & LAR & $0.000 * *(F)$ & $0.002 * *(F)$ & $0.353(F)$ \\
\hline Profundidade $(\mathrm{m})$ & PRO & $0.000 * *(F)$ & $0.891(F)$ & $0.097(F)$ \\
\hline Problema de risco & RIS & $0.002 * *(G)$ & $0.904(G)$ & $<.0001 * *(G)$ \\
\hline Tipo de risco & TIP & $0.003 * *(G)$ & $0.428(G)$ & $<.0001 * *(G)$ \\
\hline \multicolumn{5}{|l|}{ FAUNA } \\
\hline Audição ou visão de aves & AVE & $0.078(G)$ & $0.845(G)$ & $0.412(G)$ \\
\hline Vestígio de fauna & VES & $<.0001 * *(G)$ & $0.476(G)$ & $0.314(G)$ \\
\hline \multicolumn{5}{|l|}{ DANOS } \\
\hline Vandalismo em estruturas & EST & $0.788(G)$ & $0.205(G)$ & $0.537(G)$ \\
\hline Inscrições em rochas & ROC & $0.417(G)$ & $0.764(G)$ & $1.000(G)$ \\
\hline$N^{\circ}$ de árvores com inscrições/danos & ARV & $0.843(F)$ & $0.876(F)$ & $0.933(F)$ \\
\hline \multicolumn{5}{|l|}{ SANEAMENTO } \\
\hline Presença de lixo & LIX & $0.015 *(G)$ & $0.424(G)$ & $0.585(G)$ \\
\hline Presença de entulho & ENT & $0.123(G)$ & $N R^{b}$ & $0.156(G)$ \\
\hline \multicolumn{5}{|l|}{ IMPACTO SONORO } \\
\hline$N^{\circ}$ de percepções de som de veículo & VEI & $0.836(F)$ & $0.149(F)$ & $0.231(F)$ \\
\hline$N^{\circ}$ de sons de explosões (pedreira) & EXP & $0.007 * *(F)$ & $0.380(F)$ & $<.0001 * *(F)$ \\
\hline
\end{tabular}

${ }^{a}$ Valor-p para o Teste da Razăo da Verossimilhança ou Teste $G(G)$ para indicadores quantitativos e; Teste de Friedman $(F)$ para indicadores qualitativos.

* significativo ao nível de probabilidade de $5 \%$, valor-p entre $0.01-0.05$. Valor ressaltado em negrito na tabela.

** significativo ao nivel de probabilidade de $1 \%$, valor-p<0.01. Valor ressaltado em negrito na tabela.

${ }^{b} \mathrm{NR}=$ Indicador não registrado por nenhum dos avaliadores no grupo de monitores

Os indicadores número de pedras expostas, erosão e profundidade apresentaram resultados significativamente diferentes entre grupos, mas não entre indivíduos (Figura 9). 

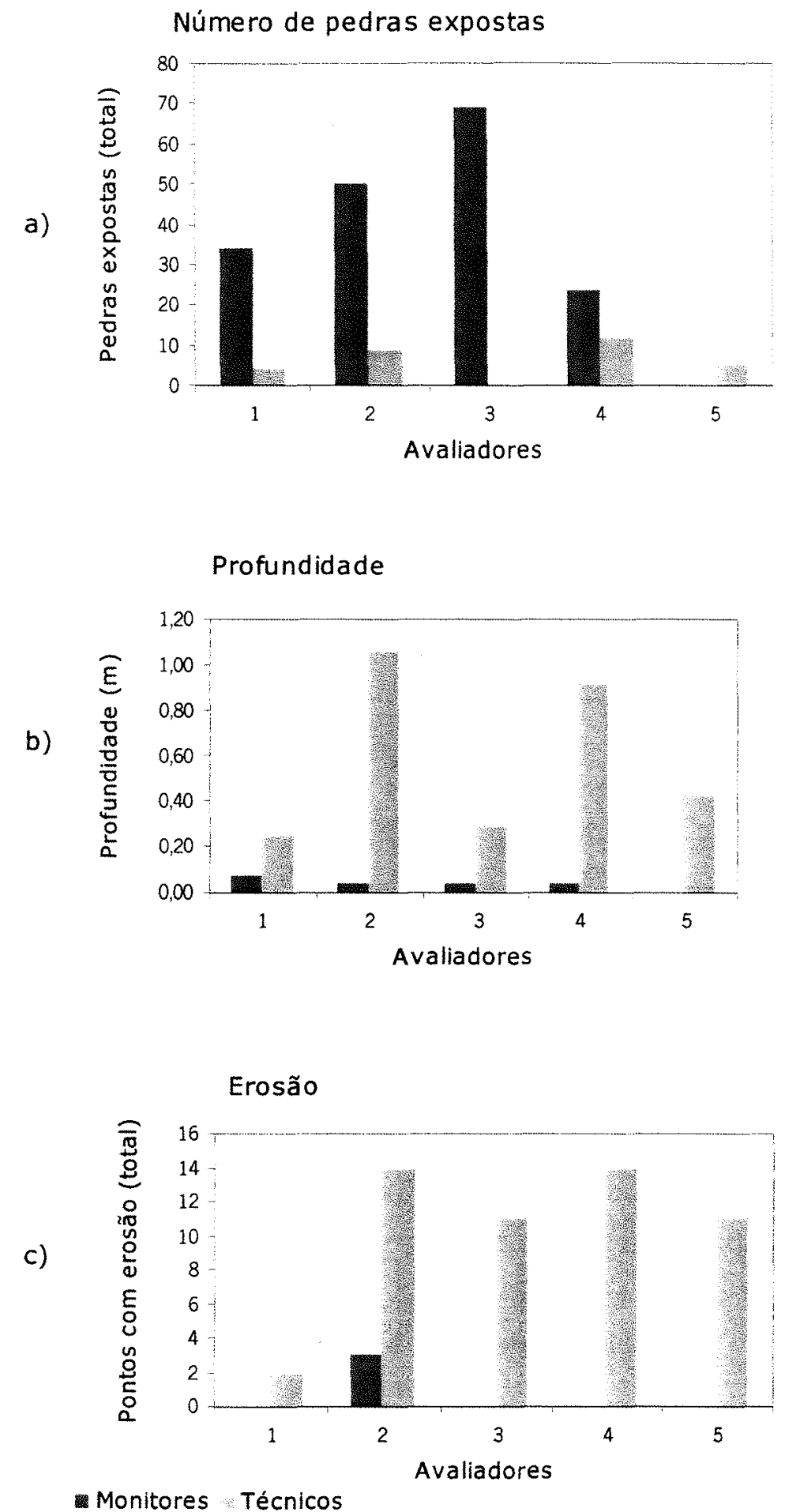

Figura 9 - Avaliação de indicadores quantitativos, (a) número de pedras expostas e (b) profundidade e qualitativos, (c) erosão, por diferentes grupos. 


\subsection{Seleção final dos indicadores}

Para a determinação dos indicadores que podem ser utilizados no programa de monitoramento futuro, foram consideradas as três formas de análise desenvolvidas neste estudo, selecionando os indicadores que: 1) Respondem ao manejo, 2) Se adequam aos critérios estabelecidos, 3) Não apresentam diferença significativa na avaliação por diferentes indivíduos.

\subsubsection{Indicadores selecionados segundo o critério referente à implementação das ações de manejo}

Todos os indicadores de leito da trilha responderam ao manejo, de forma positiva ou negativa, com exceção do indicador número de pedras expostas. Quando é evidente que a causa da exposição das pedras é o pisoteio, então este indicador poderá ser utilizado, caso contrário não é recomendado. No Parque Estadual Intervales, as pedras são expostas, na maioria das vezes, devido à condições naturais, com presença de leito rochoso. Os indicadores erosão, problema de drenagem, largura e profundidade requerem estudos mais aprofundados.

Recomenda-se a utilização da largura quando os pontos são demarcados fisicamente em campo, pois pequenas mudanças de traçado na implementação das estratégias de manejo, podem interferir nos resultados quando o objetivo é o acompanhamento das condições através do monitoramento.

$O$ indicador risco é mais bem representado quando estudadas as causas dos acidentes com usuários das trilhas. A sugestão para o registro de acidentes em áreas naturais encontra-se em Passold \& Magro (2001).

\subsubsection{Indicadores selecionados segundo avaliação de critérios}

Foram considerados bons indicadores aqueles que apresentaram os três critérios considerados necessários, ou seja respondem ao uso, respondem ao manejo e estão relacionados aos objetivos da área. Os indicadores que se adequaram aos três critérios são demostrados na Tabela 19. 
Tabela 19. Indicadores selecionados segundo critérios necessários e desejáveis.

\begin{tabular}{ll}
\multicolumn{1}{c}{ CRITÉRIOS NECESSÁRIOS } & \multicolumn{1}{c}{$\begin{array}{c}\text { CRITÉRIOS NECESSÁRIOS E } \\
\text { DESEJÁVEIS }\end{array}$} \\
\hline $\begin{array}{l}N^{\circ} \text { de indícios de fogo } \\
\text { Presença de espécies exóticas }\end{array}$ & $\begin{array}{l}N^{\circ} \text { de indícios de fogo } \\
\text { Área de solo nu } \\
N^{\circ} \text { de trilhas não oficiais } \\
\text { Erosão }\end{array}$ \\
$\begin{array}{l}\text { Área de vegetação degradada } \\
\text { Densidade }\end{array}$ & $\begin{array}{l}\text { Vandalismo em estruturas } \\
\text { Inscrições em rochas }\end{array}$ \\
$N^{\circ}$ de trilhas não oficiais & $N^{\circ}$ de árvores com danos ou inscrições \\
Erosão & Lixo na trilha \\
Problemas de drenagem & Lixo fora dos latões \\
Profundidade & Problemas de saneamento \\
Vandalismo em estruturas & $N^{\circ}$ de sons de veículo \\
Inscrições em rochas & \\
$N^{\circ}$ de árvores com danos ou & \\
inscrições & \\
Lixo na trilha & \\
Lixo fora dos latões & \\
Problemas de saneamento & \\
$N^{\circ}$ de sons de veículo &
\end{tabular}

\subsubsection{Indicadores selecionados segundo avaliação realizada por diferentes grupos}

Para a seleção dos indicadores mais representativos foi elaborada uma matriz (Tabela 19), comparando-se os resultados da classe entre grupos com monitores, entre grupos e técnicos, e entre monitores e técnicos. Os indicadores coincidentes entre as classes, com base nos dados apresentados nas tabelas 15, 16 e 17, foram marcados na matriz.

Considerando-se como indicadores mais adequados, àqueles que não apresentaram diferença significativa entre nenhum dos três grupos comparados, então seriam selecionados os indicadores: audição ou visão de aves, vandalismo em estruturas, inscrições em rochas, número de árvores com inscrições ou danos, número de percepções de sons de veículo, destacados em negrito na Tabela 20.

o segundo nível de importância considerado é a diferença não significativa entre indivíduos do mesmo grupo: número de pedras expostas, erosão, profundidade, vestígio de fauna, presença de lixo. 
Tabela 20- Matriz de seleção de indicadores de acordo com classes comparativas

\begin{tabular}{|c|c|c|c|c|c|}
\hline Indicadores quantitativos e qualitativos & Sigla & $\begin{array}{c}\text { ENTRE } \\
\text { GRUPOS E } \\
\text { MONITORES }\end{array}$ & $\begin{array}{c}\text { ENTRE } \\
\text { GRUPOS E } \\
\text { TÉCNICOS }\end{array}$ & $\begin{array}{c}\text { ENTRE } \\
\text { MONITORES } \\
\text { E TÉCNICOS }\end{array}$ & $\begin{array}{l}\text { NAOO-SIGNIFICATIVO } \\
\text { APENAS PARA } 1 \\
\text { CLASSE COMPARATIVA }\end{array}$ \\
\hline \multicolumn{6}{|l|}{ VEGETAÇÃO NAS TRILHAS } \\
\hline $\mathrm{N}^{\circ}$ de raízes expostas & RAI & & $x$ & & \\
\hline$N^{\circ}$ de árvores com bromélias ou orquideas & BRO & & & & $x$ \\
\hline Presença de Espécles Exóticas & EXO & $x$ & & & \\
\hline$N^{\circ}$ de árvores ou arbustos com galhos & GAL & & & & $x$ \\
\hline \multicolumn{6}{|l|}{ VEGETAÇÃO FORA DOS CAMINHOS OFICIAIS } \\
\hline Área de vegetação degradada $\left(\mathrm{m}^{2}\right)$ & DEG & & & & $x$ \\
\hline Composição & COM & & & $x$ & \\
\hline Densidade & DEN & & & $x$ & \\
\hline Serrapilheira & SER & & & $x$ & \\
\hline$N^{\circ}$ de trilhas não oficials & TNO & & & $\mathbf{x}$ & \\
\hline Motivo aparente (trilhas não oflciais) & MOT & & & $x$ & \\
\hline \multicolumn{6}{|l|}{ LEITO DA TRILHA } \\
\hline$N^{0}$ de pedras expostas & PED & & & $x$ & \\
\hline Erosão & ERO & & & $x$ & \\
\hline Drenagem & DRE & & & & $x$ \\
\hline Largura $(m)$ & LAR & & & & $x$ \\
\hline Profundidade $(\mathrm{m})$ & PRO & & & $x$ & \\
\hline Problema de risco & RIS & & & & $x$ \\
\hline Tipo de risco & TIP & & & & $\mathbf{x}$ \\
\hline \multicolumn{6}{|l|}{ FAUNA } \\
\hline Audição ou visão de aves & AVE & $\mathrm{x}$ & $x$ & $x$ & \\
\hline Vestiglo de fauna & VES & & & $x$ & \\
\hline \multicolumn{6}{|l|}{ DANOS } \\
\hline Vandalismo em estruturas & EST & $x$ & $x$ & $x$ & \\
\hline Inscriçð̄es em rochas & ROC & $x$ & $x$ & $x$ & \\
\hline$N^{\circ}$ de árvores com Inscriçōes ou danos & ARV & $\mathrm{x}$ & $x$ & $x$ & \\
\hline \multicolumn{6}{|l|}{ SANEAMENTO } \\
\hline Presença de lixo & LIX & & & $x$ & \\
\hline Presença de entulho & ENT & $x$ & $x$ & $x$ & \\
\hline \multicolumn{6}{|l|}{ IMPACTO SONORO } \\
\hline$N^{\circ}$ de percepções de som de veículo & VEI & $x$ & $x$ & & \\
\hline$N^{\circ}$ de sons de explosões (pedreira) & EXP & & & & $x$ \\
\hline
\end{tabular}

\subsubsection{Indicadores selecionados}

De acordo com as três formas de análise desenvolvidas neste estudo, foram selecionados os seguintes indicadores: presença de serrapilheira, número de árvores com raízes expostas, área de vegetação degradada, número de trilhas não 
oficiais, presença de lixo, número de árvores danificadas. Recomenda-se que o monitoramento seja realizado a cada dois anos.

A descrição a seguir explica como cada indicador, tanto quantitativo, como qualitativo pode ser medido, e as classes utilizadas para alguns indicadores qualitativos.

Indicador 1 - Presença de serrapilheira. Avaliar a quantidade de serrapilheira no ponto amostral $\left(0.5 \mathrm{~m}^{2}\right)$ atribuindo-se os valores: $1=$ nenhuma ou menos que uma mão cheia, 2=mão cheia ou quantidade suficiente para encher até meio balde de 5 litros, 3 =quantidade suficiente para encher mais que um balde de 5 litros.

Indicador 2 - Número de árvores com raízes expostas. Contar o número de árvores (não devem ser incluídos arbustos) com as raízes mais grossas expostas ao seu redor, até uma distância de mais que $40 \mathrm{~cm}$ da base.

Indicador 3 - Área de vegetação degradada. Identificar se a área é caracterizada como área degradada, ou seja onde ainda há presença de vegetação, ou se a área é de solo nu. A área é então medida, selecionando-se uma das formas mais adequadas para representá-la ( $1=$ retângulo, 2=triângulo, 3=círculo) para inclusão no cálculo de área, que poderá ser feito em escritório, representado em metros quadrados $\left(\mathrm{m}^{2}\right)$.

Indicador 4 - Trilhas não oficiais. Observar o número de trilhas não oficiais e classificar de acordo com as seguintes notas: $0=$ nenhuma, $1=$ uma trilha bem demarcadas, 2 =duas trilhas bem demarcadas, 3 =mais de três trilhas bem demarcadas. Descrever a causa.

Indicador 5 - Presença de lixo. Registrar a presença ou ausência de lixo visível do ponto amostrado. Pode-se descrever o tipo e a disposição do lixo, para auxiliar na identificação da causa.

Indicador 6 - Número de árvores danificadas. Contar o número de árvores que apresentam inscrições, como nomes de pessoas, escrito na casca da árvore. 


\subsection{Caderno de registro de ocorrências}

Um dos resultados desta avaliação é a de que alguns indicadores possuem características que tornam difícil o seu monitoramento através das fichas de campo, devido a casualidade com que ocorrem. O registro de ocorrências vem complementar as informações que dificilmente podem ser observadas em campo sem a ajuda das anotações dos monitores e guias do parque.

Atualmente os problemas ocorridos na área de uso intensivo do Parque Estadual Intervales não são registrados, ou como no caso de acidentes com visitantes, faz-se o registro mas de forma pouco detalhada. Assim, optou-se pelo registro das ocorrências, para que a curto e longo prazo possam ser obtidas informações, que auxiliem no processo de tomada de decisões por parte da administração do parque.

Os indicadores de impacto relacionados à danos na vegetação e fauna continuarão a ser levantados através da etapa de monitoramento, vindo as informações obtidas com o registro de ocorrências, complementar a identificação das causas prováveis dos impactos e desta forma contribuir na seleção das estratégias de manejo.

O caderno contém, basicamente, registros de ocorrências de problemas na do Parque Estadual Intervales. Sempre que acontece algum problema os monitores preenchem o caderno relatando as informações sobre a ocorrência. Desta forma, pretende-se com estas informações isolar as causas mais significativas dos problemas, analisando técnicas de manejo que objetivam reduzi-los ou controlá-los.

Cada monitor do Parque Estadual Intervales recebeu um caderno que deverá ser utilizado sempre que for presenciada uma das ocorrências abaixo listadas, indicadas nos separadores coloridos com sua respectiva simbologia:

\section{S Problemas nas trilhas \\ \% Danos à fauna e vegetação \\ $\$$ Acidentes com visitantes \\ $\lambda$ Comportamento dos visitantes}

As fichas são mostradas no Anexo $A 3$, e a descrição detalhada do preenchimento é encontrada em Passold \& Magro (2001). 


\section{CONCLUSÕES}

Impactos negativos em áreas naturais protegidas são uma conseqüência inevitável das atividades da recreação ao ar livre praticadas tanto em áreas privadas como particulares. A avaliação dos impactos recreacionais é importante, pois considera dois objetivos freqüentemente presentes nas áreas naturais, propostos pelo Sistema Nacional de Unidades de Conservação da Natureza - SNUC: proteger amostras de toda a diversidade de ecossistemas do país e promover a educação e interpretação ambiental, a recreação em contato com a natureza e o turismo ecológico (Brasil, 2000). Assim, as áreas naturais protegidas que incluem o uso público entre seus objetivos devem prever também instrumentos de monitoramento que assegurem a qualidade dos recursos naturais.

O objetivo deste estudo foi selecionar indicadores de impacto recreacional para o monitoramento do uso público em áreas naturais. Foram consideradas três formas de análise, com a seleção final dos indicadores que: 1) respondem ao manejo, 2) se adequam aos critérios estabelecidos, 3) não apresentam diferença significativa na avaliação por diferentes indivíduos.

Os resultados mostraram que a diferença nas respostas dos indicadores ao manejo implementado, tanto nas trilhas de uso intensivo quanto moderado e baixo não foram tão evidentes quanto esperados. Indicadores qualitativos e quantitativos foram selecionados com base em critérios estabelecidos para bons indicadores. As matrizes elaboradas para as formas de análise desenvolvidas neste estudo, auxiliaram no processo de seleção, sendo sugeridos os seguintes indicadores para $o$ monitoramento: presença de serrapilheira, número de árvores com raizes expostas, área de vegetação degradada, número de trilhas não oficiais, presença de lixo, número de árvores danificadas. Recomenda-se que os novos indicadores sejam testados em campo e avaliados os parâmetros dos indicadores qualitativos. 
Novos estudos devem ser conduzidos para verificar a relação efeito-causa dos indicadores de leito da trilha, como erosão, profundidade, problemas de drenagem, para se chegar a um indicador que responda da melhor forma aos critérios de bons indicadores.

Sendo a recreação uma atividade prevista, dentro dos objetivos de determinadas categorias de manejo de unidades de conservação, a questão primordial para os administradores é definir até que ponto o impacto se torna inaceitável. Assim, com o estabelecimento de padrões para os indicadores, busca-se alcançar o ideal de manejo para a área. Em longo prazo devem-se atingir $0 \%$ de ocorrência para muitos indicadores, como por exemplo, acidentes com visitantes. No entanto, mesmo com a implementação de estratégias de manejo, as mudanças nas condições podem não ser percebidas em curto prazo ou sequer surtir efeito em favor da recuperação do ambiente. Assim, para alguns indicadores, os padrões para futuros levantamentos podem continuar sendo os mesmos estabelecidos para o primeiro levantamento. Ou seja, se aceita as condições atuais, mesmo estando fora do padrão desejado.

Com a crescente pressão do turismo em áreas naturais no Brasil, recomenda-se que as instituições responsáveis adotem programas de monitoramento de impacto recreacional, como uma ferramenta para planejamento e manejo dos programas de uso público. 
ANEXOS 


\section{A1 - Ficha de campo utilizada nos levantamentos de impacto em 1999 e 2001.}

\begin{tabular}{|c|c|c|c|c|c|c|c|c|c|c|c|c|c|c|}
\hline \multicolumn{4}{|c|}{$\begin{array}{l}\text { FICHA DE MONITORAMENTO DE INDICADORES BIOFISICOS E SOCIAIS DO } \\
\text { Nome do coletor: }\end{array}$} & \multirow{2}{*}{\multicolumn{8}{|c|}{$\begin{array}{l}\text { PARQUE ESTADUAL INTERVALES } \\
\text { Clima: ( ) sol ( ) chuva ( ) nublado } \\
\text { Ficha } n^{\circ}\end{array}$}} & \multirow{2}{*}{\multicolumn{3}{|c|}{$\mathrm{m}$. }} \\
\hline \multicolumn{4}{|l|}{ Data: ___ Local: } & & & & & & & & & & & \\
\hline INDTCADOR/ Verficader & 1 & $\sqrt{2}$ & 3 & & 4 & 5 & T & 3 & 7 & & 8 & 9 & & 10 \\
\hline VEGETACAO NAS TRILHAS & & & & & & & & & & & & & & \\
\hline Número de raizes expostas & & & & & & & & & & & & & & \\
\hline Número de indícios de fogo & & & & & & & & & & & & & & \\
\hline Número de árvores com bromélias/ orquideas & & & & & & & & & & & & & & \\
\hline Presença de espécies exóticas $(\mathrm{s} / \mathrm{n})$ & & & & & & & & & & & & & & \\
\hline Número de árvores/arbustos com galhos quebrados & & & & & & & & & & & & & & \\
\hline
\end{tabular}
VEGETACAO FORA DOS CAMINHOS OFICIAIS

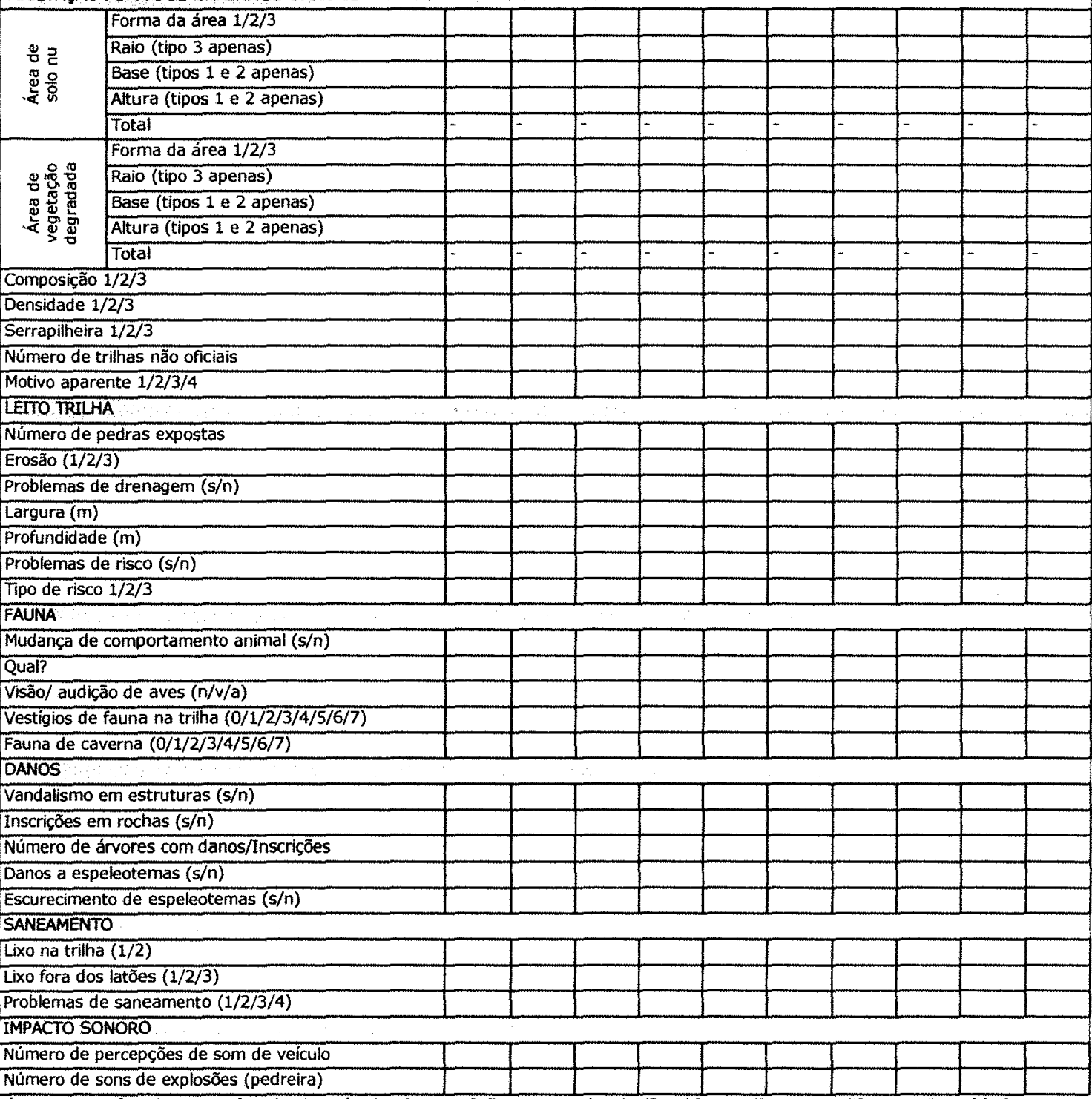

Forma da área: 1 - retângulo, 2 - triângulo, 3 - círculo; Composição: 1 - igual redor/2 - diferente/3 - muito diferente; Densidade: 1 - igual redor $/ 2$ - menos denso/3 - muito menos denso; Serrapilheira: 1 - não pisoteado/2 - pisoteado/3 - ausente; Motivo aparente: 1 - água, 2 - WC, 3 - corte, 4 -outros; Erosão; 1 - erosão lateral, 2 - sulco, 3 - canal; Risco: 1 - escorregar, 2 - fatal, 3 - outros; fauna: 1 - pegadas, 2 - carreiro, 3 toca, 4 - fezes, 5 - ossos, 6 - cheiro, 7 - visão/audição; Lixo na trilha: 1 - pouco, 2 - muito; Lixo fora dos latóes: 1 - pouco espalhado, 2 - muito espalhado, 3 - transbordando; Problemas de saneamento: 1 - dejeto, 2 - urina, 3 - fossa/esgoto, 4 - entulho. 
A2 - Indicadores selecionados no seminário realizado em maio de 2000 no Parque Estadual Intervales.

\section{Vegetação}

$\checkmark$ Presença de plantas invasoras

$\checkmark$ Poluição do ar (carros), sugestão de pesquisa

$\checkmark$ Cheiro (afugentamento $x$ atração)

$\checkmark$ Sedimentação devido a abertura e manutenção de estradas, terraplanagem para construções, fauna de rio

$\checkmark$ Morte de animais (matança, atropelamento, aves nos vidros)

$\checkmark$ Abertura de trilha/estrada (isolamento de populações, aumento da predação, diminuição da umidade, aumento de populações oportunistas)

$\checkmark$ Aumento de infra-estrutura (estradas, construções - alteração do ambiente)

\section{Ambiente cavernícola}

$\checkmark$ Crescimento de plantas

$\checkmark$ Pichação/inscrições

$\checkmark$ Pegadas/poluição visual

$\checkmark$ Deposição de lixo

$\checkmark$ Implantação de infra-estrutura

$\checkmark$ Diminuição de fauna

$\checkmark$ Retirada de material, espeleotema, organismos, pedras, solo,...

$\checkmark$ Mudança de comportamento (fauna)

$\checkmark$ Espeleotema: fuligem, sujeira, quebra, retardo no desenvolvimento

$\checkmark$ Solos: compactação, erosão, aumento da largura da trilha

$\checkmark$ Água: poluição, diminuição do gotejamento, aumento do material em suspensão

$\checkmark$ Ambiente (geral): mudança de temperatura (u.r.), aumento de co2/gases, eutrofização (dejetos humanos), introdução de organismos

\section{Fauna}

$\checkmark$ Introdução de espécies (sementes - indireto, cachorros, gatos, cavalos - doenças)

$\checkmark$ Pisoteamento/reviramento de fundo de rio - alteração na fauna aquática e peixes

$\checkmark$ Aumento de ruídos (afugentamento e diminuição da área de vida)

$\checkmark$ Esgoto (qualidade da água: fauna aquática associada)

$\checkmark$ Lixo nas trilhas, dejeto (aumento dos oportunistas, doenças)

$\checkmark$ Alimentação inadequada da fauna través do lixo espalhado e deixado pela visitação pública

\section{Solos}

$\checkmark$ Compactação, erosão/perda de material e modificação da granulometria

$\checkmark$ Cor do solo avaliado pela carta de Munsell - correlacionada com o teor de matéria orgânica

$\checkmark$ Sombreamento, espécies vegetais ocorrentes, fisionomia do solo

$\checkmark$ Análise química do solo

$\checkmark$ Erosão/assoreamento

$\checkmark$ Compactação do solo da trilha em relação à área adjacente

$\checkmark$ Nível do solo na trilha em relação à áreas adjacentes, não perturbável (perfil da trilha)

$\checkmark$ Largura da trilha

$\checkmark$ Aumento da declividade da trilha $x$ aumento da compactação

\section{Social}

$\checkmark$ Perfil do visitante (idade, profissão, hobby, escolaridade, procedência,...)

$\checkmark$ Conflito entre grupos

$\checkmark$ Presença de lixo

$\checkmark$ Relação do número de visitantes por guia

$\checkmark$ Não cumprimento da expectativa 
A3 - Fichas do Caderno de registro de ocorrências

\section{OCORRÊNCIA NAS TRILHAS}

DATA:

LOCAL (ex.:trilha, descida perto da estrada, bananeira):

\section{PROBLEMAS}

$\square$ Erosão na trilha

$\square$ Pontos com lama

Bambu caido na trilha

Árvore caída

$\square$ Deslizamento de encosta

Trilha fechada

Trilha muito fechada

Outros:

\section{MANUTENÇÃO DA TRILHA}

Limpeza da vegetação $\square$ Limpeza de canais de drenagem

Correção de inclinação $\square$ Substituição de degraus

Construção de canais de drenagem/barreiras para desviar água

Outros:

\section{MANUTENÇÃo de placas}

$\square$ Pintura nova (lixar e pintar) $\square$ Substituir placa toda

Substituir base (mourão)

Outros:

\section{INSTALAÇÃO DE ESTRUTURAS NOVAS \\ $\square$ Placa $\square$ Corrimão $\quad \square_{\text {Escada }} \quad \square$ Corda \\ Novo canal de drenagem \\ JUSTIFICATIVA}<smiles>C1=C2CCC(C1)C2</smiles> 
DATA:

LOCAL:

HORÁRIO dE OCORRÊnCIA: $\square$ Manhã $\square$ Tarde $\square$ Noite

CONDIÇÃO: $\square$ Flagrante $\square$ Não flagrante

Fotos: $\square$ Não $\square$ Sim. Arquivo no:

PESSOA OU GRUPO ENVOLVIDO:

$\square$ Visitante $\square$ Visitante regional $\square$ Escola $\square$ Desconhecido

$\square$ Funcionário $\square$ Morador não funcionário $\square$ Pesquisador

Outros:

NÚMERO DE PESSOAS NO GRUPO:

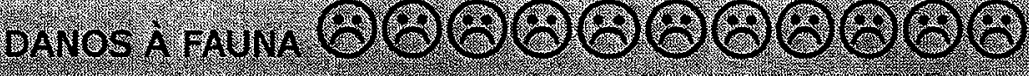

ESPÉCIE:

\section{SITUAÇÃO}

$\square$ Animal ferido $\square$ Animal morto

Animal estressado $\square$ Animal preso

$\square$ Outros:

\section{CAUSAS}

$\square$ Maus tratos $\square$ Atropelamento $\square$ Armadilha de caça

Coleta $\square$ Caça Armadilha de pesquisa

Irregularidade em coleta de pesquisador

Outros:

\section{DESCRIÇÃO}

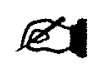



(2)

DATA:

LOCAL:

HORÁRIO DE OCORRÊNCIA:

$\square$ Manhã

$\square$ Tarde Noite

CoNDIÇÃo: $\square$ Flagrante $\square$ Não flagrante

Fotos: $\square$ Não $\square$ Sim. Arquivo no:

PESSOA OU GRUPO ENVOLVIDO:

\begin{tabular}{lll}
$\square$ Visitante & $\square$ Visitante regional \\
$\square$ Escola & $\square$ & Desconhecido \\
$\square$ Funcionário & $\square$ Morador não funcionário & $\square$ Pesquisador \\
Outros: & & \\
\hline
\end{tabular}

NÚMERO DE PESSOAS NO GRUPO:

REGISTRO DE RRESENCA DE FAUNA

\section{ESPÉCIE:}

\section{COMPORTAMENTO HUMANO EM RELACÃO AOS OUTROS ANIMAIS}

\section{AGRESSIVIDADE}

$\square$ Jogar objeto (pedra, galho)

Gritar

Cutucar o animal

$\square$ com mão ou outro objeto

\section{INTERAÇÃO}

Oferecer alimentos ou atirá-los $\square$ Chamar o animal $\square$ Rir $\square$ Tentar pegar $\square$ Imitar o som

\section{CURIOSIDADE}

$\square$ Olhar fixamente para o animal

$\square$ Fotografar

Apontar a presença do animal

com o dedo

\section{TEMOR}

Assustar-se, ficar alerta, dar um pulo para trás

Alertar para o perigo, invocando atenção e cuidado

DESCRIÇÃO (macho, fêmea, fêmea com filhote,...) 
(i) INFORMAÇÕES GERAIS

DATA DO ACIDENTE:

TRILHA OU LOCAL:

\section{DETALHES DO LOCAL:}

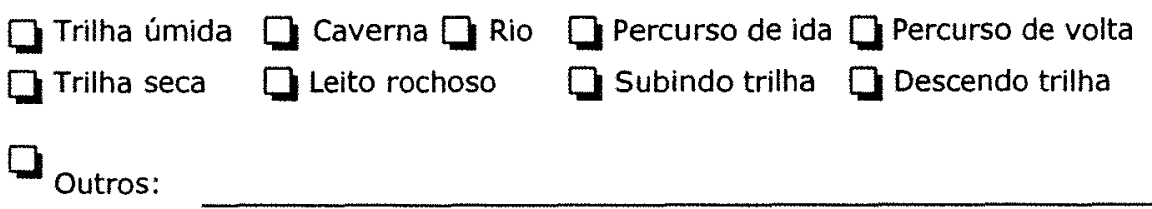

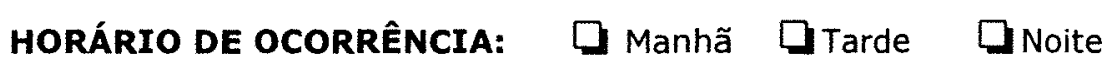
NOMES E IDADES DE PESSOAS DIRETAMENTE ENVOLVIDAS

1.Nome: Idade:

2.Nome: Idade:

3.Nome: Idade:

4.Nome: Idade:

PESSOA OU GRUPO ENVOLVIDO:

$\begin{array}{ll}\square \text { Visitante } & \square \text { Escola } \\ \square \text { Visitante regional } & \square \text { Funcionário } \\ \square \text { Outros: } & \end{array}$ NÚMERO TOTAL DE PESSOAS NO GRUPO:

NOME E CONTATO DA PESSOA ENVOLVIDA (endereço completo/telefone) ex 


\section{(i) DETALHES DO ACIDENTE}

TIPO DE FERIMENTO (pode-se assinalar mais de uma)

Fatalidade

Deslocamento de membro. Parte do corpo:

Dratura. Parte do corpo:

I Contusão. Parte do corpo:

DEstiramento. Parte do corpo:

$\square$ Corte. Parte do corpo:

Abrasão (ralado). Parte do corpo:

Dicada/mordida. Qual animal:

Wipotermia

Wemorragia

Condição preexistente

Desconhecido

Ferimento com plantas (espinhos, planta urticante, tóxica)

Psicológico

$\square$ Outros:

CAUSA IMEDIATA (pode-se assinalar mais de uma)

Calçado/vestuário inadequado

Sem capacete

Escorregou ou caiu

Raiz exposta

$\square$ Falta de capacidade física

Psicológica (medo, pânico, etc)

Sem lanterna

L Local liso: Dem caverna $\square$ em rio/cachoeira $\square$ leito da trilha

Fatores climáticos

Caminhou muito rápido

$\square$ Pedra exposta

Falta de habilidade

$\square$ Doença

Outros:

MEdIDA DE PRIMEIROS SOCORROS ADOTADA

$\square$ Não

Sim, descrever qual:

EQUIPAMENTO DE SOCORRO UTILIZADO

$\square$ Não

Sim, descrever qual:

DESCRIÇÃO DO ACIDENTE EM FORMA NARRATIVA (se necessário, use o verso da folha) 


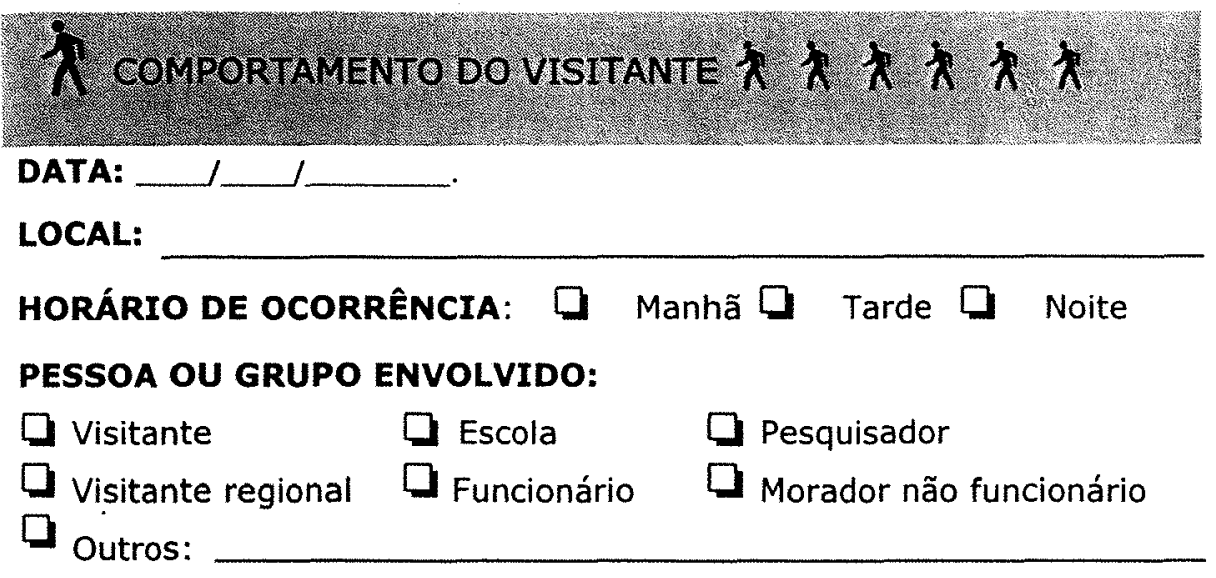

NÚMERO DE PESSOAS NO GRUPO:

口 COMPORTAMENTO POSIIIVO ही हो ही ही हो ही हो हो

\section{SITUAÇÃO}

$\square$ Ajudou em resgate Auxiliou no controle de uma situação

$\square$ Ofereceu-se como voluntário (em trabalho, em buscas,...)

$\square$ Outros:

\section{COMPORTAMENTO NECAIVO}

\section{SITUAÇÃO}

$\square$ Vandalismo em estrutura (placas, escada, banco,...)

$\square$ Visitante trouxe animal doméstico (cachorro, gato,...)
$\square$ Lixo $\square$ Fogueira $\square$ Bebida alcoólica
Outros:

\section{CONSEQUÊNCIAS}

$\square$ Suspensão do passeio $\square$ Reclamação dos visitantes

$\square$ Outros: 


\section{REFERÊNCIAS BIBLIOGRÁFICAS}

ABIDIN, Z. Z. The identification of criteria and indicators for the sustainable management of ecotourism in Taman Negara National Park, Malaysia: a Delphi consensus. Morgantown, 1999. 274p. Thesis (Ph.D.) - College of Agriculture, Forestry and Consumer Sciences, West Virginia University.

BELNAP, J. Choosing indicators of natural resource condition: a case study in Arches National Park, Utah. Journal of Environmental Management, v.22, n.4, p.635-642, 1998.

BOYERS, L.; FINCHER, M.; VAN WAGTENDONK, J. Twenty-eight years of wilderness campsite monitoring in Yosemite National Park. In: WILDERNESS SCIENCE IN A TIME OF CHANGE CONFERENCE: WILDERNESS ECOSYSTEMS, THREATS, AND MANAGEMENT, 5., Missoula, 1999. Proceedings. Missoula: USDA, Forest Service, 2000. p.105-109.

BRASIL. Ministério do Meio Ambiente. Indicadores sócio econômicos, institucionais, biológicos, ecológicos e biofísicos para o sistema de monitoramento de biodiversidade - SIMBIO. Brasília, 1999. 61p. (Relatório interno)

BRASIL. Ministério do Meio Ambiente. Lei $n^{\circ}$ 9.985, de 18 de julho de 2000 : Sistema Nacional de Unidades de Conservação da Natureza Brasília: MMA; IBAMA; Funatura; 2000, 32p.

BRASIL. Ministério do Esporte e Turismo. Pólos de ecoturismo: Brasil (compact disc). Brasília: Ministério do Esporte e Turismo; EMBRATUR; IEB; 2001. 
BRITO, C. W de. Unidades de conservação: intenções e resultados. São Paulo: Annablume, 2000. 230p.

CARVALHO, J. L.; ROBIM, M.J.; STARZYNSKI, R. A influência do pisoteio em algumas propriedades físicas do solo na trilha da praia do sul do Parque Estadual da Ilha Anchieta. In: CONGRESSO BRASILEIRO DE UNIDADES DE CONSERVAÇÃo, 2., Campo Grande, 2000. Anais. Campo Grande: Rede Nacional Pró Unidade de Conservação e Fundação $O$ Boticário de Proteção à Natureza, 2000, p.306-312.

CIFUENTES, M.A. Determinación de capacidad de carga turística en areas protegidas. Turrialba: CATIE, Programa de manejo integrado de recursos naturales, 1992. 28p. (Serie Técnica, 194)

CLARK, R.; STANKEY, G. H. The recreation opportunity spectrum: a framework for planning, management, and research. Washington: USDA, Forest Service, Pacific North Forest and Range Experiment, 1979. 32p. (General Technical Report PNW,98)

COLE, D. N. Assessing and monitoring backcountry trail conditions. Ogden: USDA, Forest Service, Intermountain Forest and Range Experiment Station, 1983. 1V. (Research paper)

COLE, D. N.; PETERSEN, M. E.; LUCAS, R. C. Managing wilderness recreation use: common problems and potential solutions. Ogden: USDA, Forest Service, Intermountain Research Station, 1987. 60p. (General Technical Report INT, 230)

COLE, D. N. ; MCCOOL, S. F. Limits of acceptable change and related planning processes: a workshop. In: LIMITS OF ACCEPTABLE CHANGE AND RELATED PLANNING PROCESS: PROGRESS AND FUTURE DIRECTIONS, Ogden, 1997. Proceedings. Ogden: USDA, Forest Service, Rock Mountain Research Station, 1997. p.1-2. 
COLE, D. N. Minimizing conflict between recreation and nature conservation. In: SMITH, D. S.; HELLMUND, P. C. Ecology of greenways. Minneapolis: University of Minnesota, 1993. cap.5, p.105-122.

COLE, D. N. The wilderness threats matrix: a framework for assessing impacts. Ogden: USDA Forest Service Intermountain Research Station, 1994. 14p. (General Technical Report INT,475)

DAVIS, J. B.; LINDVALL, M. Standards of quality for river use within the Fort Niobrara Wilderness Area. In: WILDERNESS SCIENCE IN A TIME OF CHANGE CONFERENCE: WILDERNESS VISITORS, EXPERIENCES, AND VISITOR MANAGEMENT, 4., Missoula, 1999. Proceedings. Missoula: USDA, Forest Service, 2000. p.232-235.

FORMAN, R.T.T. Land mosaics: the ecology of landscapes and regions. New York: Cambridge University, 1995. 1v.

FREIXÊDAS-VIEIRA, V. M.; PASSOLD, A. J.; MAGRO, T.C. Impactos do uso público: um guia de campo para utilização do método VIM. In: CONGRESSO BRASILEIRO DE UNIDADES DE CONSERVAÇÃo, 2., Campo Grande, 2000. Anais. Campo Grande: Rede Nacional Pró Unidade de Conservação e Fundação O Boticário de Proteção à Natureza, 2000. p.296-305.

GNASPINI, P.; TRAJANO, E. Província espeleológica do vale do ribeira, região da Fazenda Intervales, SP: exploração, topografia e biologia. Espeleo-Tema, v.6, p.41-74, 1992.

GRAEFE, A. R.; KUSS, F. R.; VASKE, J. J. Visitor impact management: the planning framework. Washington: National Park and Conservation Association, 1990. 105p.

HAMMIT, W. ;Cole, D. N. Wildland recreation: ecology and management. 2.ed. New York: John Wiley, 1998. 361p. 
HENDEE, J. C.; STANKEY, G. H.; LUCAS, R. C. Wilderness management. 2.ed. Golden: North American, 1990. 546p.

HESSELBARTH, W.; VACHOWSKI, B. Trail construction and maintenance notebook. Missoula: USDA, Forest Service, Technology and development program, 1997. 139p.

KRUMPE, E. E. The role of science in wilderness planning: a state-of-knowledge review. In: WILDERNESS SCIENCE IN A TIME OF CHANGE CONFERENCE: WILDERNESS VISITORS, EXPERIENCES, AND VISITOR MANAGEMENT, 4., Missoula, 1999. Proceedings. Missoula: USDA, Forest Service, 2000. p.134141.

KUSS, F.R.; GRAEFE, A. R.; VASKE, J. J. Visitor impact management: a review of research. Washington: National Park and Conservation Association, 1990. $256 p$.

LAH, K. J. Developing social standards for wilderness encounters in Mount Rainier National Park: Manager-defined versus visitor-defined standards. In: WILDERNESS SCIENCE IN A TIME OF CHANGE CONFERENCE: WILDERNESS VISITORS, EXPERIENCES, AND VISITOR MANAGEMENT, 4., Missoula, 1999. Proceedings. Missoula: USDA, Forest Service, 2000. p.232-235.

LEUNG, Y-F. ; MARION, J.L. The influence of sampling interval on the accuracy of trail impact assessment. Journal of Landscape and Urban Planning, v.43, 167-179, 1999 a.

LEUNG, Y.-F.; MARION, J. L. Characterizing backcountry camping impacts in Great Smoking Mountains National Park, USA. Journal of Environmental Management, v.57, p.193-203, 1999 b. 
LEUNG, Y.-F.; MARION, J. L. Recreation impacts and management in wilderness: a state-of-knowledge review. In: WILDERNESS SCIENCE IN A TIME OF CHANGE CONFERENCE: WILDERNESS ECOSYSTEMS, THREATS, AND MANAGEMENT, 5., Missoula, 1999. Proceedings. Missoula: USDA, Forest Service, 2000. p. 2347.

MAGRO, T.C.; FREIXÊdAS-VIEIRA, V. M.; ESSOE, B. et al. Plano de Uso Público: Parque Nacional do Itatiaia. Piracicaba: ESALQ, Depto. de Ciências Florestais, 2000. 194p. (Plano de uso público apresentado ao MMA; IBAMA)

MAGRO, T.C. Impactos do uso público em uma trilha no planalto do Parque Nacional do Itatiaia. São Carlos, 1999. 135 p. Tese (Doutorado) - Escola de Engenharia de São Carlos, Universidade de São Paulo.

MAGRO, T.C.; FREIXÊDAS, V. M. Manejo do impacto do uso público: capacidade de suporte. Piracicaba: ESALQ, Depto. de Ciências Florestais, 1998. 106p. (Revisão do Plano de Manejo do Parque Nacional do Iguaçu)

MANN, P. S. Introductory statistics. 2.ed. New York: John Wiley, 1995. 800p.

MANNING, R. E.; LIME, D. W. Defining and managing the quality of wilderness recreation experiences. In: In: WILDERNESS SCIENCE IN A TIME OF CHANGE CONFERENCE: WILDERNESS VISITORS, EXPERIENCES, AND VISITOR MANAGEMENT, 4., Missoula, 1999. Proceedings. Missoula: USDA, Forest Service, 2000. p.13-52.

NATIONAL PARK SERVICE. The visitor experience and resource protection (VERP) framework: a handbook for planners and managers. Denver: US Department of Interior, National Park Service, 1997. 103p.

PASSOLD, A. J.; MAGRO, T. C. Registro de ocorrências em áreas naturais protegidas. Piracicaba: $O$ autor, 2001. 1v. 
SÃo PAULO (Estado). Fundação para a Conservação e a Produção Florestal. Parque Estadual Intervales: plano de gestão ambiental - fase 1. São Paulo: Fundação para a Conservação e a Produção Florestal; Secretaria do Meio Ambiente, 1998, 256p.

SÃO PAULO (Estado). Secretaria de Estado do Meio Ambiente. Fundação para a conservação e a produção florestal do Estado de São Paulo. Intervales. São Paulo: A Fundação, 2001. 240p.

SPILDIE, D. R.; COLE, D. N.; WALKER, S. C. Effectiveness of a confinement strategy in reducing pack stock impacts at campsites in the Selway-Bitterroot Wilderness, Idaho. In: WILDERNESS SCIENCE IN A TIME OF CHANGE CONFERENCE: WILDERNESS ECOSYSTEMS, THREATS, AND MANAGEMENT, 5. Missoula, 1999. Proceedings. Missoula: USDA, Forest Service, 2000. p.199208.

STANKEY, G.H.; COLE,N.; LUCAS, R.C. et al. The limit of acceptable change (LAC) system for wilderness planning. Ogden: USDA Forest Service, 1985. 37p. (General Technical Report INT, 176)

SUN, D.; WALSH, D. Review of studies on environmental impacts of recreation and tourism in Australia. Journal of Environmental Management, v.53, p.323$338,1998$.

TAKAHASHI, L. Y. Caracterização dos visitantes, suas preferências e percepções e avaliação dos impactos da visitação pública em duas unidades de conservação do Paraná. Curitiba, 1998. 129 p. Tese (Doutorado) - Setor de Ciências Agrárias, Universidade Federal do Paraná.

VAN BUEREN, E. M. L.; BLOM, E. M. Hierarchical framework for the formulation of sustainable forest management standards. Leiden: Tropenbos Foundation, 1997. 82p. 
VIMMERSTEDT, J. P.; SCOLES, F. G.; BROWN, J. H. et al. Effects of use pattern, cover, soil drainage class, and over winter changes on rain infiltration on campsites. Journal of Environmental Quality, v.11, n.1, p.25-28, 1982.

WATSON, A.; ZAHROBSKY, J.;OLSEN, N. A summary list of indicators of natural conditions. Missoula: Wilderness Management Research Unit, Intermountain Research Station, 1990. 1V.

WHITECOTTON, R. C. A.; DAVID, M. B.; DARMODY, R. G. et al. Impact of foot traffic from military training on soil and vegetation properties. Journal of Environmental Management, v.26, p.697-706, 2000.

WORLD TOURISM ORGANIZATION. Third united conference on the least developed countries, international trade, commodities and services. http://www.worldtourism.org/newsrom/speeches/more_speeches/S0105010.html. 2001. (10 nov 2001).

WORLD TOURISM ORGANIZATION. WTO picks hot tourism trends for $\mathbf{2 1}^{\text {st }}$ century.FrancescoFrangialli.http://www.worldtourism.org/pressrel/LISBON.html. 1998 (20 out 2001).

ZAR, J. H. Biostatistical analysis. 2.ed. New Jersey: Prentice-Hall, 1984. 718p. 